\title{
WestVirginiaUniversity
}

THE RESEARCH REPOSITORY @ WVU

Graduate Theses, Dissertations, and Problem Reports

2011

\section{Avian assemblages and Red-eyed Vireo nest survival within mineland forest}

Jeremy Mizel

West Virginia University

Follow this and additional works at: https://researchrepository.wvu.edu/etd

\section{Recommended Citation}

Mizel, Jeremy, "Avian assemblages and Red-eyed Vireo nest survival within mineland forest" (2011). Graduate Theses, Dissertations, and Problem Reports. 355.

https://researchrepository.wvu.edu/etd/355

This Thesis is protected by copyright and/or related rights. It has been brought to you by the The Research Repository @ WVU with permission from the rights-holder(s). You are free to use this Thesis in any way that is permitted by the copyright and related rights legislation that applies to your use. For other uses you must obtain permission from the rights-holder(s) directly, unless additional rights are indicated by a Creative Commons license in the record and/ or on the work itself. This Thesis has been accepted for inclusion in WVU Graduate Theses, Dissertations, and Problem Reports collection by an authorized administrator of The Research Repository @ WVU. For more information, please contact researchrepository@mail.wvu.edu. 
Avian assemblages and Red-eyed Vireo nest survival within mineland forest

\author{
Jeremy Mizel
}

Thesis submitted to the Davis College of Agriculture, Natural Resources and Design at West Virginia University in partial fulfillment of the requirements for the degree of

\title{
Master of Science
}

in

Wildlife and Fisheries Resources

Petra Bohall Wood, Ph. D., Chair

James T. Anderson, Ph. D.

Jeffrey G. Skousen, Ph. D.

Division of Forestry and Natural Resources

Morgantown, West Virginia

2011

Keywords: reclamation; mine reforestation; pre-SMCRA; Forestry Reclamation Approach; Vireo olivaceus; logistic-exposure 


\section{ABSTRACT \\ Avian assemblages and Red-eyed Vireo nest survival within mineland forest Jeremy David Mizel}

Since the passage of the Surface Mining Control and Reclamation Act (SMCRA) in 1977, mined lands have generally been reclaimed to an environment characterized by severely compacted minesoils, a growth medium comprised largely of unweathered materials, and a predominance of aggressive groundcovers that inhibit native species colonization. Under these conditions, succession is arrested. Within landscapes that are fragmented by traditionally reclaimed surface mines, forest patches are smaller and forest cover on the landscape scale is reduced. As a result, forest songbirds that require large, continuous blocks of forest are negatively affected.

Some pre-SMCRA abandoned minelands contain areas of uncompacted minesoils on which hardwood forest has developed in the absence of aggressive groundcovers. Despite potential differences in tree species composition, study of the relationship between habitat structure and the avian assemblage within pre-SMCRA mineland forest could provide insight into the species assemblages that future mineland reforestation efforts might yield. Study of the reproductive success of forest songbirds within pre-SMCRA mineland forest may provide some indication as to whether this habitat is capable of sustaining breeding songbird populations. In chapter two of this thesis, I detail research in which my objectives were to: 1) examine patterns in avian assemblage structure within mineland and reference forest and to link the avian assemblage response to variables describing habitat structure and composition, and 2) contrast nest survival of Red-eyed Vireos (Vireo olivaceus) breeding within mineland and reference forest.

I conducted this research in 2011 within New River Gorge National River in southern West Virginia. I surveyed avian assemblages and sampled stand structure and composition along 28 fixed-width line transects (14 mined and 14 reference) established within four pre-SMCRA abandoned minelands and adjacent, unmined forest. Minelands within these study areas were were relatively wide (80-100 m wide on average) and contained mature forest (60-65 years old) that had developed from areas of loose-dumped spoil mounded atop benches and also within outslopes.

Using an information-theoretic approach, I developed a priori models containing habitat and temporal covariates that I hypothesized to influence the nest survival of Red-eyed Vireos. Within the same study area, I monitored vireo nests within three mineland forest plots and three reference forest plots.

Ordination of avian assemblages using non-metric dimensional scaling (NMDS) showed clear discrimination between mineland and reference assemblages. Linear and surface fitting of habitat variables showed strong correlations between the ordination and groundcover gradients, but generally non-significant relationships for gradients describing forest structure. Mineland assemblages were associated with lower levels of litter cover and depth and also had lower 
abundance of Ovenbirds (Seiurus aurocapillus), a ground-nesting and foraging species. Within mineland assemblages, the absence of a consistent pattern of relationships among species suggested a wider habitat gradient relative to reference forest.

I monitored 45 Red-eyed Vireo nests, 21 within mineland forest and 24 within reference forest. Nest survival for Red-eyed Vireos was similar within mineland and reference forest and nest patch characteristics (overstory cover and vertical foliage density) had minimal effect on nest survival. Classification tree modeling using forest type as the response variable indicated that reference nest sites were characterized by greater vertical heterogeneity.

In chapter three, I report on research initiated with the objective of examining patterns in avian assemblage structure in response to the presence of two broad classes of minelands on the landscape, compacted bench minelands and loose-dumped bench minelands. This research was conducted in 2010 and indicated the approach taken in 2011 (chapter two). I conducted fieldwork within five study sites in New River Gorge National River and Plum Orchard Wildlife Management Area (WMA). Point count transects were classified as loose-dumped benches, unmined plateau, compacted benches, and unmined steep slope. NMDS ordination indicated that minelands with loose-dumped benches had minimal effect on assemblage structure. The assemblage associated with compacted bench minelands was not discrete, but was largely discriminated from the other assemblage types. Species that use the subcanopy and midcanopy for nesting and foraging were discriminating components of compacted bench assemblages. Relative abundance of the closed-canopy guild was lower within mined forest than within unmined forest.

In total, this research has shown that failure to establish mineland stands in which heavyseeded species are a component has important implications for avian assemblage structure. Within minelands, heterogeneity in edaphic conditions and the corresponding variation in forest structure likely contributed to an inconsistent pattern in avian assemblage structure. 


\section{ACKNOWLEDGEMENTS}

I would like to thank my major advisor, Dr. Petra Wood, for her encouragement and support. Her forethought and dedicated guidance were invaluable to the development of this research and to my learning experience. I would also like to thank my committee members for their guidance, Dr. James Anderson for his careful reading of this work and insightful suggestions and Dr. Jeffrey Skousen for his expertise in mine reclamation and for providing me with an understanding of the processes involved in surface mining.

In particular, I would like to thank Jim Sheehan for his assistance with statistical analyses, expertise in GIS, and help in the field. I would also like to thank Jerry Kreiser, Mandy Proudman, and Ben Zyla for their hard work in the field.

I would also like to thank the National Park Service for providing lodging and John Perez and Andy Steel from New River Gorge National River for logistical assistance, site information, and GIS imagery. 


\section{TABLE OF CONTENTS}

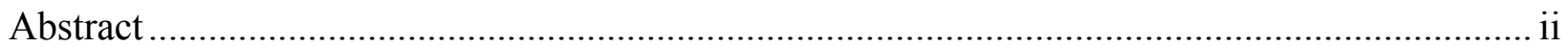

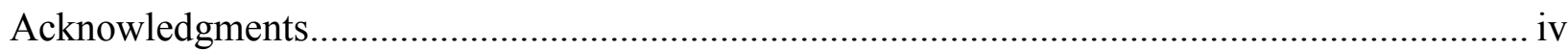

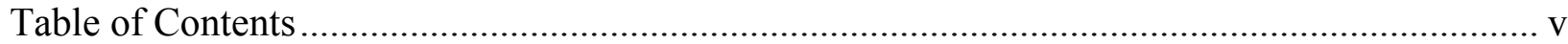

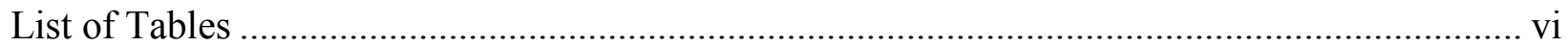

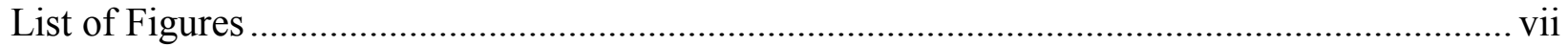

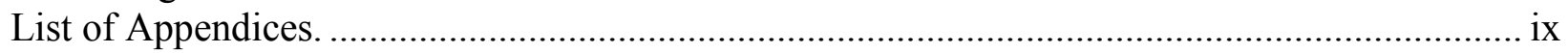

\section{CHAPTER 1: LITERATURE REVIEW}

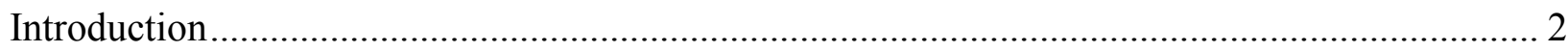

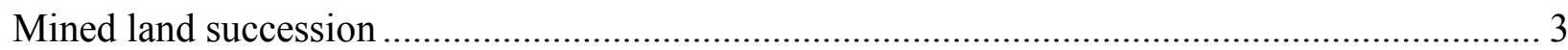

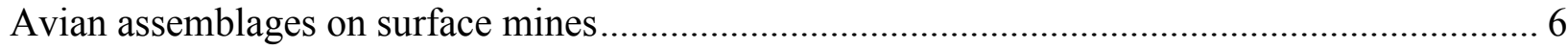

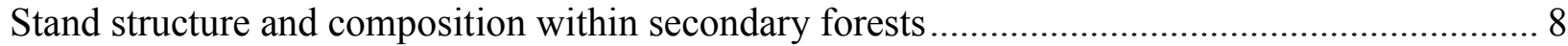

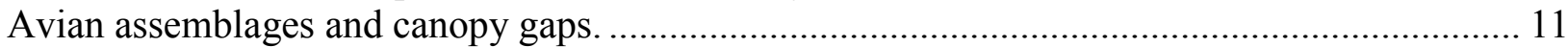

Moisture gradient influences on avian assemblages ............................................................ 13

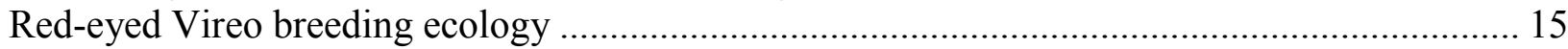

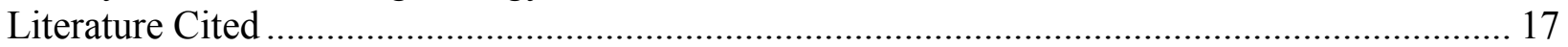

CHAPTER 2: AVIAN ASSEMBLAGES AND RED-EYED VIREO NEST SURVIVAL WITHIN MINELAND FOREST

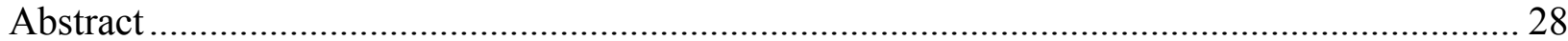

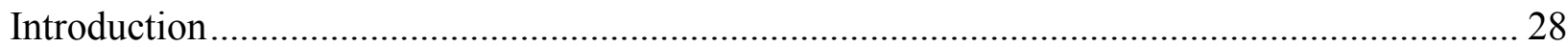

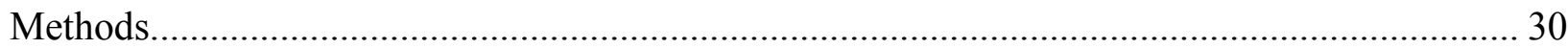

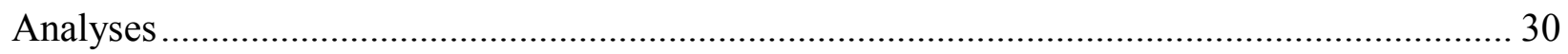

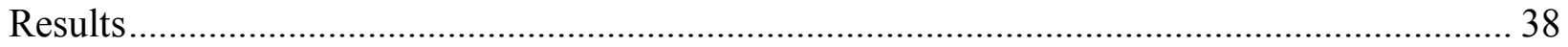

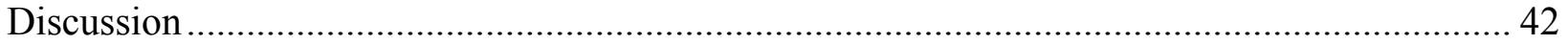

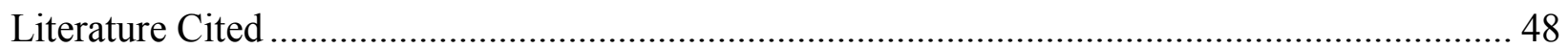

\section{CHAPTER 3: THE EFFECT OF FORESTED, ABANDONED MINE LANDS ON AVIAN} ASSEMBLAGE STRUCTURE

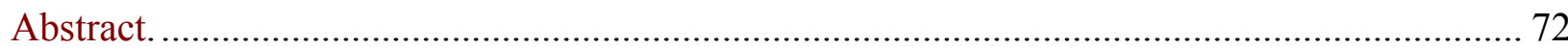

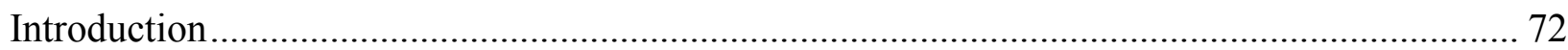

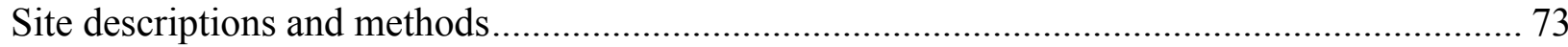

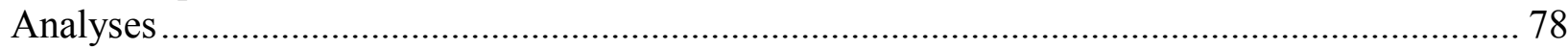

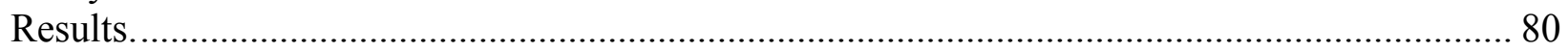

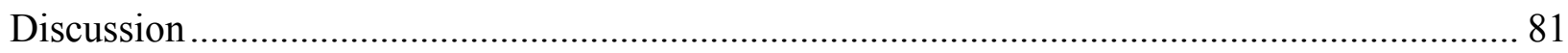

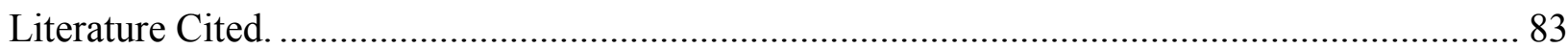




\section{LIST OF TABLES}

\section{CHAPTER 2:}

Table 1. Variables used in environmental fitting with the avian assemblage ordination. Values are the means from mineland $(n=14)$ and reference $(n=14)$ transects, each of which is the average of four plots. Data was collected in 2011 from New River Gorge Nat. River, West Virginia ..... 55

Table 2. Correlations between vector (linear) and surface (general additive modeling) fitting between habitat and topographical variables and the 3-dimensional NMDS solution for avian assemblages within mineland and reference forest. $P$-values from vector fitting are derived from 999 permutations of the data. Statistical significance was $p<0.05$.

Table 3. Mean $\left( \pm\right.$ SE) detections $\mathrm{ha}^{-1}$ for all species and habitat, foraging, and nesting guilds. Richness is the mean $( \pm \mathrm{SE})$ number of species ha ${ }^{-1} . P$-values are from Poisson GLMs using an analysis of deviance test in which the difference in deviance approximately follows a Chi-square distribution with 1 degree of freedom. Shannon diversity $\left(H^{\prime}\right)$ was tested using analysis of variance (* indicates the value of the F-statistic). All tests included site as a fixed effect. Statistical significance was $p<0.05$

Table 4. Temporal and habitat model selection results for nest survival of Red-eyed Vireos breeding within mineland and reference forest in New River Gorge National River, 2011. $\log _{\mathrm{e}}(L)$ is the value of the maximize log-likelihood function, $\mathrm{K}$ is the number of parameters estimated by the model, $\Delta \mathrm{AIC}_{\mathrm{c}}$ is the scaled value of Akaike"s Information Criterion for small sample sizes, and $w_{i}$ reflects the relative support attributed to a given model.

Table 5. Model-averaged parameter estimates, their unconditional standard errors (SE), and odds ratios (OR) with unconditional 95\% confidence intervals (CI) for habitat and temporal variables used in modeling nest survival of Red-eyed Vireos breeding within mineland and reference forest in New River Gorge National River, 2011. Odds ratios for vertical foliage density and overstory cover are for a $1 \%$ increase in the variable.

Table 6. Distribution of tree species used by Red-eyed Vireos for nest sites and the distribution of canopy gap types from those identified as being closest to vireo nests

Table 7. Means $( \pm \mathrm{SE})$ from nest measurements and habitat sampling for Red-eyed Vireo nest patches within mineland and reference forest in New River Gorge National River, West Virginia (2011). Variables used in classification tree modeling are listed under the "structural" heading (shrub and sapling cover were used instead of shrub and sapling density).

\section{CHAPTER 3:}

Table 1. Means $( \pm$ SE) for habitat characteristics associated with point counts conducted in 2010 in southern West Virginia. Plots sampled within oak-hickory forest atop the New River Plateau are categorized as loose-dumped benches $(\mathrm{n}=33)$ and unmined plateau $(\mathrm{n}=51)$. Plots sampled within mixed-mesophytic forest at steep slope sites are categorized as compacted benches $(\mathrm{n}=20)$ and unmined, steep slope $(\mathrm{n}=51)$. The critical $p$-value was set at 0.0036 using the Bonferroni 
adjustment. Means that do not share an uppercase letter are significantly different $(p<0.05$;

Tukey's multiple comparison procedure). 86

Table 2. Results from adonis analysis of avian assemblage similarity. Partial $R^{2}$ and $p$-values are given for 999 permutations of the data 87

Table 3. Mean ( \pm SE) relative abundance for all species and habitat, foraging, and nesting guilds at mined and unmined point counts conducted in 2010 in southern West Virginia. Except for Shannon diversity $\left(H^{\prime}\right), p$-values are from Poisson GLMs using an analysis of deviance test in which the difference in deviance approximately follows a Chi-square distribution with 1 degree of freedom. Shannon diversity $\left(H^{\prime}\right)$ was tested using analysis of variance $(*$ indicates the value of the F-statistic). 87

\section{CHAPTER 2:}

\section{LIST OF FIGURES}

Figure 1. Location of line transects surveyed in 2011 at the Sewell Knob site in New River Gorge National River, West Virginia. The area surveyed corresponds to $50 \mathrm{~m}$ strips on both sides of the transect line or to the full extent of the habitat when mineland width is $<100$.

Figure 2. Location of line transects surveyed in 2011 at the Molly"e Creek site (west) and Fire Creek site (east) in New River Gorge National River, West Virginia. The area surveyed corresponds to $50 \mathrm{~m}$ strips each side of the $250 \mathrm{~m}$ transect or to the full extent of the habitat when mineland width is $<100 \mathrm{~m}$.

Figure 3. Location of Red-eyed Vireo nest plots and nests that were monitored within those plots in 2011 in New River Gorge National River, West Virginia. Area and nests monitored for each plot were: Sewell Knob reference (36.4 ha, $n=14)$, Sewell Knob mine (8.8 ha, $n=9$ ), Little Stoney mine (20.8 ha, $n=7)$, Molly ${ }^{\text {ee }}$ Creek reference (17.4 ha, n=5), Molly"es Creek mine (10.1 ha, $\left.n=5\right)$, and Stonecliff reference (5.4 ha, $\mathrm{n}=5)$.

Figure 4. Distribution of tree species groups by size class from reference $(n=56)$ and mineland forest plots $(n=56)$ sampled along bird survey transects in New River Gorge National River, West Virginia (2011). This is expressed as the proportion of tree density within a size class. White oaks include chestnut and white oak. Red oaks include black, scarlet, and northern red oak.

Figure 5. Diameter distribution from reference $(n=56)$ and mineland forest plots $(n=56)$ sampled along bird survey transects in New River Gorge National River, West Virginia (2011)............ 65

Figure 6. Boxplot of basal area $\left(\mathrm{m}^{2} \mathrm{ha}^{-1}\right)$ for transects within mineland and reference forest. .... 65

Figure 7. Dimensions 1 and 2 from a 3-dimensional NMDS solution for avian assemblages within mineland $(\mathrm{M})$ and reference $(\mathrm{R})$ forest. Stress was 15.3 for the 3-dimensional solution (2 convergent solutions after 6 runs). The vectors plotted are for those variables that had linear 
$p<0.05$ (axes 1-3). The length of the arrow corresponds to the correlative strength of the gradient-ordination relationship. Weighted mean positions for all bird species are shown. Species codes are listed in Appendix C.

Figure 8. NMDS ordinations fit with surface contours using GAM for A) leaf litter depth, (contours are in $\mathrm{cm}$ ) and B) litter cover. Mean weighted locations for species in the ground gleaning guild (Ovenbird and Wood Thrush). Linear and surface fit $r^{2}$ values for the ordinationgradient relationship are shown above their corresponding frames. Surface fits are significant $(p<0.001)$. Assemblage type is overlaid; mineland (M) and reference (R) forest.

Figure 9. Mean dissimilarity dendrogram for mineland $(\mathrm{M})$ and reference $(\mathrm{R})$ forest assemblages. Mean between-group dissimilarity $(\mathrm{Bbar})=0.460$. Mean within-group dissimilarity $(\mathrm{Wbar})=$ 0.410 .

Figure 10. Mean detections $\mathrm{ha}^{-1}( \pm \mathrm{SE})$ for habitat, nesting, and foraging guilds within mineland (gray) and reference forest (white). The boxplot for Shannon diversity $\left(H^{\prime}\right)$ is also shown. 68

Figure 11. Model-averaged estimates and 95\% CIs for period survival of Red-eyed Vireo nests within mineland and reference forest and for daily survival for laying/incubation and nestling stages.......

Figure 12. Classification tree for structural characteristics within Red-eyed Vireo nest patches within mineland $(M ; n=21)$ and reference $(R ; n=24)$ forest in New River Gorge National River, West Virginia (2011). Nodes are classified according to the dominant forest type.

\section{CHAPTER 3:}

Figure 1. Location of point count stations surveyed in 2010 in southern West Virginia. Plateau study sites (unmined and loose-dumped bench transects) are shown in the top frame and steep slope sites (unmined and compacted bench transects) are shown in the bottom two frames ....... 88

Figure 2. Spoil ridges atop the Fire Creek study site 89

Figure 3. Spoil ridge along Sewell Knob study site.

Figure 4. Vine-captured gap at the base of a highwall along a compacted bench study site in Plum Orchard WMA.

Figure 6. Effective detection radii (EDR) with 95\% confidence intervals for Black-and-white Warbler, Blue-headed Vireo, Hooded Warbler, Ovenbird, Red-eyed Vireo, Scarlet Tanager, and Wood. Estimates are for mined (gray bars) and umined (white bars) point counts. Depending on the function used in the detection model, the EDR estimates the distance at which the probability of detection declines below 0.5 (Laake et al. 1993, Simons et al. 2006). 
Figure 7. Percent vertical foliage density within the subcanopy (0-6 m), midcanopy (6-18 m), and overstory $(>18 \mathrm{~m}$ ) for compacted bench sites, unmined steep slope sites, loose-dumped bench sites, and unmined plateau sites.

Figure 8. Dimensions 1 and 2 from a 3-dimensional NMDS solution for avian assemblages in mined (compacted and loose-dumped benches) and unmined forest. Stress was 20.6 for the 3dimensional solution (2 convergent solutions after 6 runs). Sp. codes are listed in Append. C... 93

Figure 9. Mean dissimilarity dendrogram for compacted bench assemblages (C), loose-dumped bench assemblages (L), unmined plateau assemblages $(\mathrm{P})$, and unmined steep slope assemblages $(\mathrm{S})$. Mean between-group dissimilarity $(\mathrm{Bbar})=0.502$. Mean within-group dissimilarity (Wbar) $=0.453$

Figure 10. Relative abundance ( $\pm \mathrm{SE}$ ) for habitat, nesting, and foraging guilds for mined (gray) and unmined (white) point counts. The boxplot for Shannon diversity $\left(H^{\prime}\right)$ is also shown

\section{LIST OF APPENDICES}

Appendix A. Study area for line transect surveys and Red-eyed Vireo nest monitoring in New River Gorge National River, West Virginia (2011).

Appendix B. Aerial photograph (1945) showing early surface mining atop the New River Plateau. Initial mining at two study sites (2010-2011) is indicated on the photograph. 97

Appendix C. Breeding bird species detected during 2010-2011 surveys

Appendix D. Relative importance values for tree species from reference $(n=56)$ and mineland $(n=56)$ forest plots sampled in New River Gorge National River, West Virginia in 2011

Appendix E. Detections $\mathrm{ha}^{-1}$ and percent occurrence for bird species detected along line transects in 2011 in mineland and reference forest in New River Gorge Nat. River, West Virginia ........ 100

Appendix F. Location of study sites within Plum Orchard Wildlife Management Area (WMA) and New River Gorge National River in southern West Virginia (2010-2011)

Appendix G. Relative importance values for tree species from plots categorized as loose-dumped benches $(n=33)$, unmined plateau forest $(n=51)$, compacted benches $(n=20)$, and unmined, steep slope forest $(n=51)$. Only species with relative importance $\geq 0.05$ are shown. Plots were sampled in southern West Virginia in 2010 . 102

Appendix H. Percent occurrence and relative abundance $( \pm \mathrm{SE})$ for bird species detected during point count surveys conducted in southern West Virginia, in 2010. Plateau surveys were conducted atop the New River Plateau in unmined, oak-hickory forest $(n=20)$ and adjacent forest bisected by loose-dumped minelands $(n=17)$. Steep slope surveys were conducted in unmined, 
mixed-mesophytic forest $(n=14)$ and in adjacent forest bisected by compacted minelands $(n=14)$ 


\section{Chapter 1}

\section{INTRODUCTION}




\section{INTRODUCTION}

Surface mining first attained widespread use in Appalachia in the 1940s (Potter et al. 1951). In general, surface mining in the steep slopes of this region has taken the form of contour mining and larger-scale mountaintop mines where mountaintop removal, contour, and auger/highwall mining are being employed.

Post-mining land use has varied greatly since the 1940s (Potter et al. 1951). Prior to the enacting of the Surface Mining Control and Reclamation Act (SMCRA) in 1977, mines used a "shoot and shove" method for extraction resulting in an exposed highwall, bench-land along its face, and an outslope comprised of loose spoil that had been pushed below. Mines were left in these "shoot and shove" configurations and reclamation practices varied from state to state (Brown 1962). In states such as Ohio, early reclamation efforts typically involved planting hardwoods and pine on mined lands (Paton el al. 1970, Rodrigue 2001). In West Virginia, surface mines were generally abandoned without planting (Brown 1962, Rodrigue 2001).

SMCRA requires that mine operators "backfill, compact, and grade in order to restore the approximate original contour (AOC) of the land with all highwalls, spoil piles, and depressions eliminated" (Office of Surface Mining Reclamation and Enforcement 2008). Mine companies, dozer operators, and regulatory agencies responded with expectations of a uniformily smooth reclamation landscape. The traditional post-SMCRA reclamation environment is one in which unweathered materials contribute heavily to the growth medium, minesoils have been severely compacted from immoderate grading, and aggressive groundcovers have been sown to prevent erosion (Burger et al. 2002).

During the two decades that followed the passage of SMCRA (1977), surface mines were generally reclaimed to grassland or woodland that was planted or seeded to black locust (Robinia pseudo-acacia), Virginia pine (Pinus virginiana), eastern white pine (P. strobes), autumn olive (Elaeagnus umbellate), and highly tolerant, aggressive ground covers including Kentucky-31 tall fescue (Festuca arundinacea) and sericea lespedeza (Lespedeza cuneata) (Burger et al. 2002, Burger et al. 2005, Showalter and Burger 2006). Most native hardwood species have poor survival and growth in this environment (Burger et al. 2002).

The Appalachian Regional Reforestation Initiative (ARRI) was established by the Office of Surface Mining in 2004 with the primary objective of encouraging surface mine reforestation through a method termed the Forestry Reclamation Approach (FRA). The Forestry Reclamation 
Approach is a series of field-tested guidelines directed at advancing forest succession on minelands (Burger and Fannon 2009, Skousen et al. 2009). Components of this approach include creating an uncompacted growth medium in which hardwoods are capable of exhibiting normal survival and growth and seeding non-aggressive groundcovers which do not completely inhibit forest plant invasion (Burger et al. 2005).

\section{MINED LAND SUCCESSION}

During the initial stages of mined land succession, reduced plant species diversity is often the result of the loss of seed and bud banks (dormant meristems from which vegetation may resprout) (Groninger et al. 2007). Although the original topsoil was typically buried during preSMCRA mining, some of the disproportionately large diameter trees that exist on these sites today are evidence of individuals that sprouted from stump and root remnants that survived the mining disturbance (Croxton 1928, Riley 1975, Rodrigue 2001). Wind and bird-disseminated species capable of withstanding varied and often harsh site conditions are the first to colonize minesoils (Burger and Zipper 2009). Colonization by less stress-tolerant species occurs as soils become conditioned and nitrogen and organic material accumulate (Burger and Zipper 2009). Colonization by heavy-seeded species, primarily via animal dispersal, can be extremely limited within the interior of mine sites (Showalter and Burger 2006).

On pre-SMCRA mines which have reverted to forest, stand composition tends to be dominated by pioneer species including: red maple (Acer rubum), yellow poplar (Liriodendron tulipifera), bigtooth aspen (Populus grandidentata), sourwood (Oxydendrum arboretum), eastern cottonwood (Populus deltoides), American elm (Ulmus americana), American sycamore (Platanus occidentalis), birch (Betula spp.), and boxelder (Acer negundo) (Skousen et al. 1994, Zeleznik and Skousen 1996, Rodrigue 2001). On a 45-year-old, unreclaimed surface mine in western Pennsylvania, Brenner et al. (1984) found that oak and hickory importance was only 5\% whereas red maple importance was 60\%. Ashby (1984) described two potential trajectories for minelands in the Midwest: a xeric forest type, likely to develop from acidic minesoils with shales as a major constituent, and a mesophytic forest type, developing from more fertile minesoils in areas of moisture collecting topography.

Studies of pre-SMCRA mines that were planted with trees have found productive forests in which the hardwood and pine species that were planted dominate the overstory (Zeleznik and 
Skousen 1996, Rodrigue 2001, Rodrigue and Burger 2002). Rodrigue and Burger (2002) found that site indices for pre-SMCRA reforested sites (pine and hardwood plantings) in the Midwest were similar to site indices of reference forest. However, they found more variability in the site indices of their Eastern sites in comparison to reference forest. Red maple, black cherry, green ash, and sycamore were frequent subcanopy invaders. On 46-year-old mine sites in Ohio that were planted to trees, maple and elm were the most abundant volunteer tree species (Zeleznik and Skousen 1996).

Vegetation development on pre-SMCRA minelands is influenced by a combination of factors including: the edaphic properties of minesoils (Game et al. 1982, Ashby 1984, Skousen et al. 1994, Rodrigue 2001), the composition and structure of the adjacent, undisturbed plant community (Riley 1975, Skousen et al. 2006), the shape and size of the mining disturbance (Hardt and Forman 1989), post-mining disturbance processes (i.e. erosion), and stochastic variability in the introduction of species and in the distribution of biological legacies (i.e. downed woody debris) (Game et al. 1982, Walker and Chapin 1987, Skousen et al. 1994, Rodrigue 2001). As a consequence of variability in site conditions, vegetation development is often patchy (Game et al. 1982, Skousen et al. 1994, Rodrigue 2001). The irregular composition of minesoils and the resulting fine-scale heterogeneity in spoil acidity and rock and shale content is often a primary factor in producing spatial and compositional heterogeneity in vegetation development (Skousen et al. 1994, Rodrigue 2001). Skousen et al. (1994) investigated natural revegetation on abandoned mine land (AML) sites (pre-SMCRA unreclaimed surface mines) in West Virginia. Soil $\mathrm{pH}$ and acidity were highly influential in the formation of vegetation communities. On soils with a high $\mathrm{pH}$ and low acidity, herbaceous species were predominant, precluding tree establishment. On soils with a low $\mathrm{pH}$ and high acidity, tree species and acidtolerant grasses were able to establish in favorable microsites created by nurse-logs, brush piles, or small ridges and depressions with elevated levels of moisture and seed capture (Skousen et al. 1994). This type of colonization of dispersed microsites fits with the model of patch succession observed by Game et al. (1982) in a study of vegetation dynamics on small (3.7-10.4 hectares), unreclaimed surface mines in Missouri (Skousen et al. 1994). Game et al. (1982) found that invading species established within scattered microsites which then expanded and eventually coalesced. Colonizing vegetation may also spread inward from the forest-mine edge through the amelioration of growing conditions initially in association with the forest edge environment and 
then subsequently by the progression of pioneer species into the interior of the site (Rodrigue 2001).

Skousen et al. (2006) studied differences in vegetation and soils between outslope and flat top locations and adjacent reference forest at 20-year-old, reclaimed mountaintop mines in West Virginia. Flat top locations had been seeded with aggressive grasses and legumes whereas outslopes had received fairly little seeding. Consequently, tree coverage was significantly higher on outslopes than flat top locations. Red maple, black locust (Robinia pseudo-acacia), sourwood, autumn olive, black birch (Betula lenta), and yellow poplar were common on outslopes and red maple and black locust were the primary tree species on flat top locations. Outslope soils generally consisted of native soils and weathered spoil materials, whereas flat top soils were composed of a larger proportion of unweathered materials. Flat top soils had a higher $\mathrm{pH}$ and were thinner and more compacted than outslope soils. In some places along flat top locations, soil depth extended only $5-10 \mathrm{~cm}$ before the underlying rock was reached. The thick and loose condition of outslope soils in combination with the absence of an herbaceous component produced stands that structurally and compositionally resembled forest on undisturbed sites. On 46-year-old mine sites in Ohio, Zeleznik and Skousen (1996) did not find differences in the bulk density of leveled minesoils, unleveled minesoils, and undisturbed soils, possibly indicating that compaction from leveling was never particularly severe and/or that bulk density had been reduced over time.

On many post-SMCRA mines where minesoils are severely compacted and competition from reclamation groundcovers inhibit native species colonization, revegetation towards midand late-successional hardwood forest would be possible only after a period of several hundred years (Johnson and Skousen 1995, Wade 1989, Burger and Zipper 2009). Compaction impedes germination, water infiltration, and the rooting of colonizing plants (Holl 2002, Bosworth 2003, Groninger et al. 2007, Emerson et al. 2009, Skousen et al. 2009). Minesoils with poor physical and chemical properties are characterized by higher mineral content, lower organic matter and nutrient content, higher rock fragment content, reduced water retention capacity, and lower porosity (Thurman and Sencindiver 1986, Johnson and Skousen 1995, Williams 2003, Burger and Zipper 2009). Minesoils may be more acidic than native soils or they may contain more alkaline, unweathered sandstone or shale materials (Emerson et al. 2009). On sites with alkaline soils, tree growth may be relatively slow and colonization by trees may also be prolonged 
(Johnson and Skousen 1995, Emerson et al. 2009). With the loss of native soils during excavation, the resulting minesoils are to varying degrees unweathered, a condition dependent on proportions of unweathered gray sandstone, shales, and weathered brown sandstone (Emerson et al. 2009, Skousen et al. 2009). Unweathered gray materials are buried deeper in the geologic profile and consequently develop as soil horizons over a longer period of time (Skousen et al. 2009). Even with a "substitute" soil layer of unweathered materials, soil horizons with properties suitable for tree growth may develop within three years (Sencindiver and Ammons 2000, Emerson et al. 2009). On pre-SMCRA mines, hydric minesoils may develop in association with areas that are poorly drained such as sloughs that follow the base of the highwall (Atkinson et al. 1998). Often along mine benches, poor drainage is the result of underlying bedrock or compacted minesoils (Atkinson et al. 1998).

\section{AVIAN ASSEMBLAGES ON SURFACE MINES}

Surface mined lands may support diverse avian communities (Karr 1968, Brenner and Kelly 1981, Wood et al. 2001, Lacki et al. 2004, Bulluck and Buehler 2006, Patton 2007, Carrozzino 2009). Studies of nest success on reclaimed surface mines have focused on grassland songbirds and evidence has been mixed as to whether these represent source or sink populations (Wray et al. 1982, Ammer 2003, Monroe and Ritchison 2005). Little information exists on the reproductive success of early successional and mature forest songbirds nesting on surface mines.

Recent research has illustrated the significant effect surface mining has on mature forest songbirds, Cerulean Warblers (Dendroica cerulea) in particular. Cerulean Warblers preferentially select ridgetop habitat for breeding and, intuitively, mountaintop mining represents significant habitat loss for this species (Bosworth 2003, Weakland and Wood 2005, Wood et al. 2006). Additionally, Wood et al. (2006) found that Cerulean Warbler abundance decreased significantly in proximity to mine edge. This pattern of avoidance is particularly strong within 340 meters of mine edge, but also holds to distances of 900 meters (Bosworth 2003, Weakland and Wood 2005, Wood et al. 2006). Additionally, Weakland and Wood (2005) found that Cerulean Warbler territory density was much reduced in mining fragmented forests $(0.7$ territories/10 ha) versus intact forest (4.6 territories/10 ha). Lacki et al. (2004) surveyed riparian forest before and after surface mining activity and subsequent reclamation. In adjoining, unmined forest, they observed post-mining declines in Ovenbird and Hooded Warbler (Wilsonia 
citrina) abundance and the absence of Worm-eating and Cerulean Warblers from all post-mining surveys.

Some research indicates that interior-edge species such as Cerulean Warbler may increase in abundance in association with narrow-cut contour mining. In the Cumberland Mountains of Tennessee, Yahner and Howell (1975) surveyed breeding avian assemblages associated with a 20-year-old pre-SMCRA contour mine and within adjacent, undisturbed forest. Within the forest margin extending $15 \mathrm{~m}$ outward from the mine, Cerulean Warbler density was 20.1 detections/ha in comparison to 10.6 detections/ha within adjacent, undisturbed forest. In eastern Kentucky, Crawford et al. (1978) investigated the short-term effects of contour mining on breeding bird assemblages in adjacent forest. His survey route was $50 \mathrm{~m}$ downslope of the ridgeline, on the backside of which lay the mining operation. Cerulean Warblers were absent during pre-mining surveys (1975), but were detected at densities of 12.7 males/ha during the first year of mining (1976) and 18.9 males/ha by the completion of mining (1978). Additionally, Buehler et al. (2006) observed territorial Cerulean Warbler males within young forest ( $<30$ years old) that had developed on unreclaimed contour mines in Tennessee.

The seeding of exotic grasses and legumes and the level of compaction associated with post-SMCRA reclamation likely produces poor-quality early successional habitat (Rosenberg and Dettmers 2004). Woody plant invasion on mountaintop mines is generally sparse and relegated to forest edges (Handel 2003). On mountaintop mines and in adjacent forest in southern West Virginia, Wood et al. (2001) found higher species richness and total abundance for bird communities in shrub-pole mine habitat than for grassland mine habitat, intact forest, and fragmented forest.

Bulluck and Buehler (2008) studied Golden-winged Warblers breeding on reclaimed contour mines (14-26 years old) in the Cumberland Mountains of Tennessee. Over three seasons, the daily survival rate for Golden-winged Warbler nests ranged from 0.9641-0.9834. Chapman et al. (1978) surveyed bird communities on contour mines in southern West Virginia. Bird diversity was highest on mines that were 8-10 years post-reclamation, and several shrubland bird species were absent from mines more than 12 years post-reclamation. Absent species included: Goldenwinged Warbler, Yellow-breasted Chat (Icteria virens), Prairie Warbler (Dendroica discolor), and Common Yellowthroat (Geothlypis trichas). They found higher species diversity in adjacent unmined forest than within any of their mined sites. 
Few studies have investigated avian assemblages on forested minelands. In southwest Virginia, Carrozzino (2009) surveyed bird communities on 5-12 year old reclaimed mines, 13-25 year old reclaimed mines, 2-18 year old clearcuts, managed pastureland, 30-60 year old preSMCRA mines, and reference forest. She found the highest species richness on pre-SMCRA mines because these sites were primarily edge-dominated shrub-pole habitats. Karr (1968) studied avian assemblages along a chronosequence of strip-mined lands in Illinois. Included among his study sites was a 6.2 ha section of bottomland forest on land that had been strip-mined approximately 60 years prior to the study. Several species, including Kentucky Warbler (Oporornis formosus), Cerulean Warbler, Northern Parula (Parula americana), American Redstart (Setophaga ruticilla), Acadian Flycatcher (Empidomax virescens), Blue-gray Gnatcatcher (Polioptila caerulea), and Prothonotary Warbler (Protonotaria citrea), established territories on the mineland forest plot but were absent from a nearby tract of undisturbed forest.

\section{STAND STRUCTURE AND COMPOSITION WITHIN SECONDARY FORESTS}

Mature eastern forests are primarily second-growth stands initiated during extensive clearcutting during the late 1800s and early 1900s (Lorimer 1989). Canopy gap dynamics within secondary forests differ from those functioning within stands of old-growth forest (Clebsch and Busing 1989, Lorimer 1989, Weishampel et al. 2007). In secondary forests, rapid lateral crown expansion often limits the duration in which the canopy remains open (Lorimer 1989). In uneven-aged forests, older trees are generally limited in their ability to initiate rapid growth in response to increased growing space (Hart and Grissino-Mayer 2008). Additionally, the larger gap sizes that are characteristic of uneven-aged forests may preclude canopy closure via lateral crown expansion (Hart and Grissino-Mayer 2008). Consequently, subcanopy individuals may capture this growing space via height growth (Hart and Grissino-Mayer 2008). Dominants within secondary forests are also younger than those within old-growth forests and therefore less frequent gap makers (Lorimer 1989).

Yellow poplar is a shade-intolerant, rapidly growing species capable of forming monospecific canopies on sites that have experienced significant anthropogenic disturbance (Lafon 2004). More extensively, it is distributed sporadically within mesophytic forests where it captures large canopy gaps primarily on moist sites (i.e. coves and north-facing slopes) (Mudrick et al. 1994, Lafon 2004). Clebsch and Busing (1989) studied gap dynamics within a stand of 
mixed-mesophytic old growth forest and within an adjacent, 67-year-old, yellow poplar dominated stand that had established upon an abandoned agricultural field. Gaps within the yellow poplar stand were narrowly distributed within $<100 \mathrm{~m}^{2}$ size classes, whereas the old growth stand contained gaps in a range of size classes including some exceeding $280 \mathrm{~m}^{2}$. Within the yellow poplar stand, tree crowns were generally non-overlapping, but restricted in their breadth by the uniform distribution of adjacent crowns. As a result, individual tree mortality produced small openings that were evenly distributed across the stand.

In western Virginia, Lafon (2004) investigated stand dynamics within forest that had established on former agricultural land abandoned in the late 1940s. On both mesic and relatively xeric sites within this stand, the canopy was dominated by a single cohort of yellow poplar. Polesized white ash (Fraxinus americana) and red maple were abundant and, according to the author, may eventually form the dominant canopy species on the relatively xeric sites within this stand. However, Lafon (2004) suggests that yellow poplar forest may persist on the majority of the site through capture of multiple-treefall gaps created by ice storms. He suggests that, at this particular stage of development, large treefall gaps are necessary for the initiation of additional cohorts.

In pine-hemlock-northern hardwood forest, Weishampel et al. (2007) studied the canopy structure of stands initiated under varied disturbance intensities from a 1938 hurricane and subsequent salvage logging operations. They used Light Detection and Ranging (LiDAR) remote sensing data to calculate canopy top height $(\mathrm{CH})$, an index of canopy height diversity $(\mathrm{CD})$, and an index of canopy evenness (CE). The latter two are indices of vertical stratification of canopy layers from the forest floor. The more severely disturbed stands had significantly lower CD indices, shorter canopies by less than one meter, and higher levels of spatial autocorrelation for $\mathrm{CH}$. According to the authors, these findings indicate that the canopies of the more severely disturbed stands have reduced horizontal and vertical structural heterogeneity relative to undisturbed and moderately disturbed stands.

Pronounced vertical stratification is often found within stands in which species composition is characterized by significant differences in interspecific growth rates and shade tolerance (Guldin and Lorimer 1985). Additionally, species with lower shade tolerance tend to have less densely foliated canopies. Consequently, their presence in the canopy may allow greater persistence of tolerant species (i.e. red maple) within the subcanopy (Lorimer and Krug 1983). 
Disturbance regimes in eastern deciduous forests have seen significant alteration since European settlement. Within pre-settlement, mixed hardwood forests, anthropogenic and natural fire contributed to the establishment and maintenance of oak-dominated forests (Nowacki and Abrams 2008). Within post-settlement mixed hardwood forests, timber cutting for fuelwood and lumber and the slash fires that accompanied harvests formed the primary disturbance regime until the advent of fire suppression in the 1920s and 1930s (Nowacki and Abrams 2008). The frequency of fires and the extent of logging was such that oaks came to further dominate mixed hardwood forests (Nowacki and Abrams 2008). In the absence of fire and with the abatement of land clearing, oak dominance has waned as shade tolerant species are capable of overtopping oak regeneration at all but the more xeric sites (Nowacki and Abrams 2008). Consequently, species composition is shifting towards mesophytic species (Nowacki and Abrams 2008).

Relative to oak-dominated forests, the canopy closure and high leaf area associated with stands dominated by mesophytic hardwoods, typically results in higher relative humidity and reduced air movement and radiation within the subcanopy (Nauertz et al. 2004, Nowacki and Abrams 2008). Decomposition of leaf litter and downed woody debris is also more rapid within the cool, moist microclimate existing within forests dominated by mesophytic species (Nowacki and Abrams 2008). In addition to this microclimatic influence, the structural properties and decay rates of the leaves and wood of oaks and hickories differ from those of mesophytic species and therefore contribute to differences in decomposition dynamics within these two forest types (Nowacki and Abrams 2008). As a result of high tannin and lignin concentrations and low nitrogen and calcium concentrations, oak leaves are less palatable to detritivores and consequently decompose slower than leaves of many mesophytic species (Fox et al. 2010). Mudrick et al. (1994) found that yellow poplar and red maple leaf litter decomposed significantly faster than chestnut oak litter.

In Ohio and Indiana, Fox et al. (2010) compared ground and shrub-nesting bird assemblages within oak dominated forests and forests dominated by sugar maple and successional species (i.e. yellow poplar, black cherry (Prunus serotina), and slippery elm (Ulmus fulva). They found that leaf litter depth was significantly reduced in the maple dominated forests relative to oak dominated forests. Ground nesting species including Ovenbird, Black-and-white Warbler, and Worm-eating Warbler were absent in maple dominated forests whereas they were abundant in oak dominated forests. Eastern Towhee (Pipilo erythrophthalmus), Indigo Bunting, 
and Northern Cardinal (Cardinalis cardinalis) were more abundant in maple dominated forests. In a series of leaf litter decomposition experiments, they found that oak leaves decomposed significantly slower than successional species including yellow poplar. Fox et al. (2010) suggest that decreased litter depth and, consequently, a scarcity of high quality nest sites and foraging habitat contributed to the absence of ground-nesting songbirds within maple dominated forests.

In part by virtue of their specialized foraging strategies and nest architecture, forest songbirds may show preferences for particular tree species as foraging and nest substrates on the basis of characteristic foliage and branch structure (Holmes and Robinson 1981, Holmes and Robinson 1988). Several studies indicate that these preferences are generally for oak and hickory species and not mesophytic species, such as red maple and yellow poplar (Gabbe et al. 2002, George 2009, Newell 2010). In bottomland forest in Illinois, insectivorous forest birds showed strong foraging preferences for kingnut (Carya laciniosa) and bitternut hickories (Carya cordiformis) (Gabbe et al. 2002). Cerulean Warblers selectively foraged in kingnut hickory and avoided red maple. Some forest songbirds may not be adapted for capturing arthropods on red maple foliage due to the length of its petioles and the size of its leaves (Franzreb 1978, Holmes and Robinson 1981, Holmes and Schultz 1988, Rodewald and Abrams 2002). Relative to other hardwood species, some research has illustrated that oaks host a greater diversity of lepidopteran species (Summerville et al. 2003). In a study within oak-dominated forests and maple-dominated forests in Ohio, lepidopteran assemblages were strongly organized by the dominant canopy species (Summerville and Crist 2008). In a comparison of bird communities within maple and oak dominated stands, Rodewald and Abrams (2002) found reduced abundance for the bark gleaning guild in maple dominated stands across spring, fall, and winter. They attribute this

pattern to the availability of acorns in oak-dominated forests. In Ohio, Cerulean Warblers, Scarlet Tanagers (Piranga olivacea), Blue-gray Gnatcatchers, and Eastern Wood-Pewees (Contopus virens) placed nests in white oak (Quercus alba) in disproportion to its availability and avoided placing nests in red maple (Newell 2010).

\section{AVIAN ASSEMBLAGES AND CANOPY GAPS}

Lertzman et al. (1996) separate canopy openings into two categories: "developmental gaps" and "edaphic gaps". Edaphic gaps are the product of soil, topographic, or geomorphic features including streams, boulders, cliffs, and standing water. They represent "persistent open 
space" owing to the absence or arrested state of successional dynamics. Developmental gaps result from the mortality of one or several trees and are closed through lateral crown expansion or vertical height growth of interior gap vegetation.

The natural mortality of one or several trees is a primary component of disturbance regimes functioning within eastern deciduous forests and consequently contributes much of the habitat hetereogeneity within these forests (Runkle 1982). Greenberg and Lanham (2001) found that total breeding bird abundance was higher within hurricane-created gaps compared to adjacent, closed-canopy forest. Species richness was also significantly higher in gaps. Among Neotropical migrants, Indigo Bunting (Passerina cyanea), Hooded Warbler, Blue-headed Vireo, and Worm-eating Warbler were significantly more abundant in gaps. Only Ovenbird was significantly more abundant in closed-canopy forest. Red-eyed Vireo and Scarlet Tanager were detected in similar densities within gaps and closed-canopy forest.

Research conducted during spring and fall migration has found a positive correlation between migrant abundance within treefall gaps and elevated levels of both fruit and arthropod abundance (Blake and Hoppes 1986, Martin and Karr 1986). During the post-breeding period, adults and juveniles of a number of forest-interior species including Wood Thrush, Worm-eating Warblers, Ovenbirds, and Scarlet Tanagers demonstrate selective use of dense, shrub layer vegetation occurring within a variety of harvest treatments and edge habitats (Anders et al. 1998, Vega Rivera et al. 1998, Pagen et al. 2000, Dellinger 2007, McDermott and Wood 2010, Vitz and Rodewald 2010). During the breeding season, the nature of interior-edge species" association with openings in the canopy is not thoroughly understood. Openings in the forest canopy result in increased light reaching the understory and residual canopy, which in turn results in elevated primary productivity within gaps (Blake and Hoppes 1986, Martin and Karr 1986, Smith and Dallman 1996, Gorham et al. 2002). Canopy gaps may provide some forest songbirds with dense foliage in the understory and peripheral canopy in which to conceal nests (Greenberg and Lanham 2001). Increased foliage density and vertical complexity within gaps may also increase foraging efficiency among leaf-gleaning species (Blake and Hoppes 1986, Martin and Karr 1986, Smith and Dallman 1996, Gorham et al. 2002). The opening of the canopy may result in conditions (a warmer understory microenvironment and elevated primary productivity) that favor the growth of flying insect populations (Blake and Hoppes 1986, Smith and Dallman 1996, Gorham et al. 2002, George 2009). In studies of partial harvesting, Eastern Wood Pewees, a 
flycatching species, generally respond positively to the opening of the canopy (Annand and Thompson 1997, Newell 2010). In addition, Smith and Dallman (1996) suggest that Blackthroated Green Warblers (Dendroica virens) may use canopy gaps as nodes of territory advertisement and delineation due to the acoustic qualities of gaps and their structural contrast relative to the surrounding forest.

Several studies have investigated bird use of harvested gaps in relation to fruit and arthropod abundance. In general, the relationship between bird use and resource availability within harvested gaps is unclear, possibly as an outcome of seasonal variation in resources and high arthropod diversity (Moorman and Guynn 2001, Kilgo 2005, Bowen et al. 2007). In research conducted in bottomland forest in South Carolina, arthropod abundance and Hooded Warbler attack rates, an indication of foraging efficiency, were both higher $>100 \mathrm{~m}$ from group selection gaps than along gap edges and at intermediate distances (Kilgo 2005). Kilgo (2005) suggests that arthropod abundance during the breeding season may not have been limiting across the extent of the study area.

While a number of bird community studies have focused on the effects of induced edges, relatively few have investigated the effects of inherent or persistent edges resulting from soil, topographic, or geomorphic features (Matheson and Larson 1998). Along the Niagara Escarpment in Ontario, Matheson and Larson (1998) investigated differences in forest bird assemblages within four cliff associated habitats (plateau, cliff edge, cliff face, and talus slope). Patterns of species richness differed between their sites; however, they consistently observed the lowest species richness in plateau woodlands and higher species richness along cliff edges and talus slopes.

\section{MOISTURE GRADIENT INFLUENCES ON AVIAN ASSEMBLAGES}

Appalachian oak forest varies structurally and compositionally along a soil moisture and fertility gradient, characteristics which are primarily determined by topographic and geologic factors (McEvoy et al. 1980). Previous studies have shown patterns in bird density and occurrence along moisture gradients (Bertin 1977, Swift et al. 1984, Petit et al. 1985, McShea et al. 1995, Murray and Stauffer 1995).

Petit et al. (1985) quantified variation in breeding bird assemblages along a relative humidity gradient. Bird species richness and understory foliage density were positively 
correlated with relative humidity; overall abundance was not. Several species, including Redbellied Woodpecker (Melanerpes carolinus), Hairy Woodpecker (Picoides villosus), Wood Thrush, and Ovenbird, were more abundant within plots with higher relative humidity. In forested wetlands in Massachusetts, overall bird density was positively correlated with the small shrub density, coverage of standing water, and depth of soil muck. Species richness was positively correlated with small shrub density and depth of soil muck (Swift et al. 1984). From surveys conducted along a stream to upland forest gradient, Murray and Stauffer (1995) placed Scarlet Tanager, Red-eyed Vireo, Ovenbird, and Blue-headed Vireo within a xeric upland forest assemblage and Wood Thrush and Black-throated Green Warbler within a mesic forest assemblage.

Dettmers and Bart (1999) developed and evaluated spatial, microhabitat-based models for eastern forest songbirds. Models for Acadian Flycatcher and Worm-eating Warbler identified these species as having relatively restrictive microhabitat preferences for concave, moisture collecting topography (e.g. ravines and stream bottoms). Hooded Warbler, Eastern-Wood Pewee, Cerulean Warbler, and Scarlet Tanager were associated with convex terrain (e.g. adjacent to or on hilltops and ridges) and drier moisture conditions. Within this group, species ${ }^{\text {ee }}$ microhabitat preferences varied according to slope position and steepness and moisture conditions. Ovenbird, Red-eyed Vireo, and Wood Thrush were associated with a range of microhabitat conditions and were therefore dispersed relatively evenly across the study area.

In a habitat selection study of sympatric populations of Wood Thrush and Veery (Catharus fuscescens), Bertin (1977) found that moisture regime, as measured by visible soil characteristics, accounted for $76.0 \%$ and $78.4 \%$, respectively, of the variation in territory characteristics between occupied and unoccupied habitat. Both species frequently established territories along streams, seeps, and springs. Bertin (1977) suggests that thrushes as well as other ground-nesting and foraging species may use relative humidity and temperature as proximate cues to habitat suitability.

In research conducted in northwestern Virginia, McShea et al. (1995) found that Kentucky Warblers were significantly associated with red maple dominated forest and rarely established territories in oak-hickory forest. McShea et al. (1995) suggest that the preference for the red maple forest type may reflect the increased moisture associated with these sites. The 
density of Kentucky Warbler prey, invertebrates taken from leaf litter and gleaned from foliage, may be greater in these moist environments (McShea et al. 1995).

\section{RED-EYED VIREO BREEDING ECOLOGY}

Breeding habitat in which Red-eyed Vireos are generally most abundant is characterized by high levels of canopy closure, basal area, and vertical stratification (James 1971, Williamson 1971, Stauffer and Best 1980, Yahner 1986, Marshall and Cooper 2004). However, use extends to habitats with low levels of canopy cover and complexity: city parks, residential areas, and citrus groves (Graber et al. 1985, Mills 1989, Cimprich et al. 2000). Conclusions from research aimed at quantifying Red-eyed Vireo area-sensitivity and edge avoidance have been inconsistent among varied forest landscapes (Freemark and Collins 1992, Villard 1998, Burke and Nol 2000, Dunford et al. 2002).

In a study of Blue-headed (Vireo solitaries) and Red-eyed Vireo (Vireo olivaceus) habitat use in the southern Appalachians, Hudman and Chandler (2002) found that white oaks, conifers, and ericaceous shrubs were more abundant in Blue-headed Vireo territories whereas red oak and red maple were more abundant in Red-eyed Vireo territories.

Marshall and Cooper (2004) found that Red-eyed Vireo territory size was inversely correlated to the volume of foliage within a territory. Foliage volume was positively associated with caterpillar density during the nestling stage. Additionally, the timing of the nestling stage corresponded to the lowest levels of caterpillar and arthropod abundance over the course of the breeding season. The authors suggest that Red-eyed Vireos use foliage density as a structural cue in determining the size of a three-dimensional territory that will contain sufficient resources for successful brood rearing. Consequently, foliage density has implications for all aspects of vireo breeding ecology, including nest survival (Marshall and Cooper 2004).

Red-eyed Vireos show a high degree of plasticity in terms of the heights at which nests are placed (Martin 1988). Several studies (Lawrence 1953, Southern 1958, Rice 1974, Graber et al. 1985) observed mean nest heights within a range of 2.5-4.3 m. Other studies have reported mean nest heights that reflect greater variability; $10.7 \pm 5.8 \mathrm{~m}$ (mean $\pm \mathrm{SD})$ for a study in New Hampshire (Robinson 1981) and 7.0 $\pm 5.7 \mathrm{~m}(\mathrm{mean} \pm \mathrm{SD})$ for a study in the central Appalachians (DeCecco et al. 2000). Differences in reported nest heights may also reflect the difficulty in locating nests placed higher in the canopy (Rodewald 2004). Rodewald (2004) 
found that Red-eyed Vireo nests located by luck had a mean height of $3.5 \pm 0.6 \mathrm{~m}$ (mean $\pm \mathrm{SE}$ ), whereas nests located via parental behavior had a mean height of $10.1 \pm 1.1 \mathrm{~m}$. Martin (1988) suggests that differences in reported nest heights for Red-eyed Vireos may be adaptive in the sense that they are ultimately related to minimizing vertical overlap with conspecifics.

In a study of the breeding ecology of Red-eyed Vireos in Pennsylvania, characteristics of nest patch vegetation were not indicative of nest fate (Siepielski et al. 2001). The authors suggest that forest cover on the landscape scale may be more influential in terms of structuring predator assemblages and affecting reproductive success (Donovan et al. 1997, Siepielski et al. 2001, Rodewald 2002). They also hypothesize that vireo nest site selection may not be adaptive in the presence of predator assemblages unique to landscapes with significant anthropogenic disturbance. Rodewald (2002) found 2-2.6 times lower daily nest survival rates for ground and mid-canopy nesting species in forested landscapes fragmented by agriculture relative to landscapes fragmented by silviculture. She found lower densities of corvids and squirrels within silviculture-fragmented landscapes, indicating that a higher density and diversity of predators are associated with the enduring non-forest habitat within agriculture-fragmented landscapes (Rodewald and Yahner 2001, Rodewald 2002). Within contiguous forest fragmented only by narrow forest roads and low density housing, Gale et al. (1997) found no difference in the number of Worm-eating Warbler pairs fledging host and Brown-headed Cowbird young between study plots located in small and large patches. 


\section{Literature Cited}

Ammer, F.K. 2003. Population level dynamics of Grasshopper Sparrow populations breeding on reclaimed mountaintop mines in West Virginia. Ph. D. Thesis, West Virginia University, Morgantown, WV, $132 \mathrm{pp}$.

Anders, A. D., J. Faaborg, and F. R. Thompson. 1998. Postfledging dispersal, habitat use, and home-range size of juvenile Wood Thrushes. Auk 115:349-358.

Annand, E.M., and F.R. Thompson, III. 1997. Forest bird response to regeneration practices in central hardwood forests. Journal of Wildlife Management 61:159-171.

Ashby, W.C. 1984. Plant succession on abandoned mine lands in the eastern U.S. p. 613-631. In Proceedings of the National Symposium and Workshop on Abandoned Mined Land Reclamation. Bismarck, ND. 21-22 May 1984.

Atkinson, R.B., W.L. Daniels, and J. Cairns, Jr. 1998. Hydric soil development in depressional wetlands: A case study from surface mined landscapes. p. 182-196. In S.K. Majumdar, E.W. Miller, and F.J. Brenner (ed.) Ecology of wetlands and associated systems. Penn. Acad. Sci. Easton, PA.

Bertin, R. I. 1977. Breeding habitats of the wood thrush and veery. Condor 79:303-311.

Blake, J. G. and W. G. Hoppes. 1986. Influence of resource abundance on use of tree-fall gaps by birds in an isolated woodlot. Auk 103:328-340.

Bosworth, S. 2003. Cerulean Warbler relative abundance and frequency of occurrence relative to large-scale edge. Master's Thesis, West Virginia University, Morgantown, WV, 53 pp.

Bowen, L. T., C. E. Moorman, and J. C. Kilgo. 2007. Seasonal bird use of canopy gaps in a bottomland forest. Wilson Journal of Ornithology 119:77-88.

Brenner, F. J., and J. Kelly. 1981. Characteristics of bird communities on surface mined lands in Pennsylvania. Environmental Management 5:441-449.

Brenner, F. J., M. Werner, and J. Pike. 1984. Ecosystem development and natural succession in surface coal mine reclamation. Minerals and the Environment 6:10-22.

Brown, J.H. 1962. Success of tree planting on strip-mined areas in West Virginia. West Virginia University Agricultural Station Bulletin 473.

Buehler, D. A., Welton, M. J., and T. A. Beachy. 2006. Predicting Cerulean Warbler habitat use in the Cumberland Mountains of Tennessee. Journal of Wildlife Management 70:17631769.

Bulluck, L. P., and D. A. Buehler. 2006. Avian use of early successional habitats: are regenerating forests, utility right-of-ways and reclaimed surface mines the same? Forest 
Ecology and Management 236:76-84.

Bulluck, L. P., and D. A. Buehler. 2008. Factors influencing Golden-winged Warbler (Vermivora chrysoptera) nest-site selection and nest survival in the Cumberland Mountains of Tennessee. The Auk 125:551-559.

Burger, J.A., Mitchem, D.O., and D.A. Scott. 2002. Field assessment of mine site quality for establishing hardwoods in the Appalachians . Pages 226-240 in Proceedings, 2002 National Meeting of the American Society for Mining and Reclamation. Lexington, KY.

Burger, J., Graves, D., Angel, P., Davis, V., and C. Zipper. 2005. The Forestry Reclamation Approach. Forest Reclamation Advisory No. 2. U.S. Office of Surface Mining, ARRI, Washington, DC

Burger, J.A. and A.G. Fannon. 2009. Capability of reclaimed mined land for supporting reforestation with seven Appalachian hardwood species. Pages 176-191 in 26th: National Meeting of the American Society of Mining and Reclamation.

Burger, J. A., and C. E. Zipper. 2009. How to restore forests on surface-mined land. Reclamation guidelines for surface mined land in southwest Virginia series. Powell River Project, Virginia Cooperative Extension. Pub. 460-123.

Burke, D. M., and E. Nol. 2000. Landscape and fragment size effects reproductive success of forest-breeding birds in Ontario. Ecological Application 10(6):1749-1761.

Carrozzino, A.L. 2009. Evaluating wildlife response to vegetation restoration on reclaimed mine lands in southwestern Virginia. Master"es Thesis, Virginia Polytechnic Institute and State University, Blacksburg, VA. 141 pp.

Chapman, D. L., B. S. McGinnes, and R. L. Downing. 1978. Breeding bird populations in response to the natural revegetation of abandoned contour mines. Pages 328-332 in Proceedings from Surface Mining and Fish/Wildlife Needs in the Eastern United States, 3-6 December 1978, Morgantown, West Virginia, USA

Cimprich, D.A., Moore, F.R., and M.P. Guilfoyle. 2000. Red-eyed Vireo (Vireo olivaceus). In The Birds of North America, No. 527 (A. Poole and F. Gill, eds). The Birds of North America, Inc., Philadelphia, PA

Clebsch, E. E., and R. T. Busing. 1989. Secondary succession, gap dynamics, and community structure in a southern Appalachian cove forest. Ecology 70:728-735.

Crawford, H. S., D. M. Hardy, and W. A. Abler. 1978. A survey of bird use in strip mined areas in southern West Virginia. Pages 241-246 in Proceedings from Surface Mining and Fish/Wildlife Needs in the Eastern United States, 3-6 December 1978, Morgantown, WV

Croxton, W. C. 1928. Revegetation of Illinois coal stripped lands. Ecology 9(2):155-175. 
DeCecco, J.A., Marshall, M.A., Williams, A.B., Gale, G.A., and R.J. Cooper. 2000. Comparative seasonal fecundity of four Neotropical migrants in middle Appalachia. Condor 102: 653-663.

Dellinger, T.A. 2007. Post-fledging ecology and survival of neotropical songbirds on a managed Appalachian forest. Doctoral Thesis. West Virginia University, Morgantown, WV, 134 pp.

Dettmers, R. and Bart, J. 1999. A GIS modeling method applied to predict forest songbird habitat. Ecol. Appl. 9:152-163.

Donovan, T. M., Jones, P. W., Annand, E. M., and F.R. Thompson, III. 1997. Variation in localscale edge effects: mechanisms and landscape context. Ecology 78:2064-2075.

Dunford, W., Burke, D.M., and E. Nol. 2002. Assessing edge avoidance and area sensitivity of Red-eyed Vireos in southcentral Ontario. Wilson Bulletin 114(1):79-86.

Emerson, P., Skousen, J., and P. Ziemkiewicz. 2009. Survival and growth of hardwoods on brown versus gray sandstone on a surface mine in West Virginia. J. Environ. Qual. 38: $1821-1829$.

Fox, V.L., Buehler, C.P., Byers, C.M., and S.E. Drake. 2010. Forest composition, leaf litter, and songbird communities in oak- vs. maple-dominated forests in the eastern United States. Forest Ecology and Management 259:2426-2432.

Franzreb, K.E. 1978. Tree species used by birds in logged and unlogged mixed-coniferous forests. Wilson Bulletin 90:221-238.

Freemark, K., and B. Collins. 1992. Landscape ecology of birds breeding in temperate forest fragments. Pages 443-454 in Ecology and conservation of Neotropical migrant landbirds (J.M. Hagan, III and D.W. Johnston, Eds.). Smithsonian Inst. Press, Washington, D.C.

Gabbe, A. P., Robinson, S.K., and J. D. Brawn. 2002. Tree-species preferences of foraging insectivorous birds: implications for floodplain forest restoration. Conservation Biology $16: 462-470$.

Gale, G. A., L. A. Hanners, and S. R. Patton. 1997. Reproductive success of Worm-eating Warblers in a forested landscape. Conservation Biology 11:246-250.

Game, M., J. E. Carrel, and T. Hotrabhavadra. 1982. Patch dynamics on abandoned surface mines. Journal of Ecology 70(3):707-720.

George, G.A. 2009. Foraging ecology of male Cerulean Warblers and other Neotropical migrants. Ph.D. Thesis, West Virginia University, Morgantown, WV 
Gorham, L. E., S. L. King, B. D. Keeland, and S. Mopper. 2002. Effects of canopy gaps and flooding on homopterans in a bottomland hardwood forest. Wetlands 22:541-549.

Graber, J.W., Graber, R.R., and E.L. Kirk. 1985. Illinois birds: vireos. Biol. Notes no. 68. Illinois Nat. Hist. Surv., Urbana.

Grant, T.A., Shaffer, T.L., Madden, E.M., Pietze, P.J., 2005. Time-specific variation in passerine nest survival: new insights into old questions. Auk 122:661-672.

Greenberg, C.H., Lanham, J.D., 2001. Breeding bird assemblages of hurricane-created gaps and adjacent closed canopy forest in the southern Appalachians. For. Ecol. Manage. 154, $251-260$.

Groninger, J., J. Skousen, P. Angel, C. Barton, J. Burger, and C. Zipper. 2007. Mine reclamation practices to enhance forest development through natural succession. Forest Reclamation Advisory no. 5. U.S. Office of Surface Mining, ARRI, Washington, DC

Guldin, J.M., and C.G. Lorimer. 1985. Crown differentiation in even-aged northern hardwood forests of the Great Lakes region, U.S.A. For. Ecol. Management 10:65-86.

Handel, S.N. 2003. Terrestrial plant (spring herbs, woody plants) populations of forested and reclaimed sites. Appendix in Mountaintop Mining/Valley Fills in Appalachia: Final Programmatic Environmental Impact Statement. United States Environmental Protection Agency. Philadelphia, PA

Hardt, R. H., and R. T. T. Forman. 1989. Boundary form effects on woody colonization of reclaimed surface mines. Ecology 70(5):1252-1260.

Hart, J.L., and H.D. Grissino-Mayer. 2008.Vegetation patterns and dendroecology of a mixed hardwood forest on the Cumberland Plateau: implications for stand development. Forest Ecol. Management 255:1960-1975.

Holl, K.D. 2002. Long-term vegetation recovery on reclaimed coal surface mines in the eastern USA. J. Appl. Ecol. 39:960-970.

Holmes, R.T., and S.K. Robinson. 1981. Tree species preferences of foraging insectivorous birds in a northern hardwoods forest. Oecologia 48:31-35.

Holmes, R.T., and S.K. Robinson. 1988. Spatial patterns, foraging tactics, and diets of groundforaging birds in a northern hardwoods forest. Wilson Bulletin 100(3):377-394.

Holmes, R. T., and J. C. Schultz. 1988. Food availability for forest birds: effects of prey distribution and abundance on bird foraging. Canadian Journal of Zoology 66:720-728.

Hudman, S.P., and C.R. Chandler. 2002. Spatial and habitat relationships of Red-eyed and Blueheaded Vireos in the southern Appalachians. Wilson Bulletin 114(2):227-234. 
James, F. C. 1971. Ordinations of habitat relationships among breeding birds. Wilson Bulletin $83: 215-236$.

Johnson, C.D., and J.G. Skousen. 1995. Minesoil properties of 15 abandoned mine land sites in West Virginia. Journal of Environmental Equality 24:635-643.

Karr, J. R. 1968. Habitat and avian diversity on strip-mined land in east-central Illinois. Condor 70: $348-357$.

Kilgo, J. C. 2005. Harvest-related edge effects on prey availability and foraging of Hooded Warblers in a bottomland hardwood forest. Condor 107:626-635.

Lacki, M. J., J. L. Fitzgerald, and J. W. Hummer. 2004. Changes in avian species composition following surface mining and reclamation along a riparian forest corridor in southern Indiana. Wetlands Ecology and Management 12:447-457.

Lafon, C.W. 2004. Stand dynamics of a yellow poplar (Liriodendron tulipifera L.) forest in the Appalachian Mountains, Virginia, USA. Dendrochronologia 22:43-52.

Lawrence, L. K. 1953. Nesting life and behavior of the Red-eyed Vireo. Canadian Field Naturalist 67:47-76.

Lee, P., and J.T. Rotenberry. 2005. Relationships between bird species and tree species assemblages in forested habitats of eastern North America. Journal of Biogeography 32: 1139-1150.

Lertzman, K. P., G. D. Sutherland, A. Inselberg, and S. C. Saunders. 1996. Canopy gaps and the landscape mosaic in a coastal temperate rain forest. Ecology 77:1254-1270.

Lorimer, C.G. 1989. Relative effects of small and large disturbances on temperate hardwood forest structure. Ecology 70(3):565-567.

Lorimer, C.G., and A.G. Krug. 1983. Diameter distributions in even-aged stands of shadetolerant and midtolerant tree species. American Midland Naturalist 109(2):331-345.

McDermott, M. E., and Wood, P.B. 2010. Influence of cover and food resource variation on post-breeding bird use of timber harvests with residual canopy trees. Wilson Journal of Ornithology 122(3): 545-555.

McEvoy, T.J., T.L. Sharik, and D.W. Smith. 1980. Vegetative structure of an Appalachian oak forest in southwestern Virginia. Amer. Midi. Naturalist 103:96-105.

McShea, W.J., McDonald, W.V., Meier, R., Morton, E.S. and Rappole, J. 1995. Long term trends in habitat selection by Kentucky warblers as determined by GIS. Auk 112:375381. 
Marshall, M.R., and R.J. Cooper. 2004. Territory size of a migratory songbird in response to caterpillar density and foliage structure. Ecology 85(2):432-445.

Martin, T. E. 1988. Processes organizing open-nesting bird assemblages: competition or nest predation? Evolutionary Ecology 2:37-50.

Martin, T. E. 1994. Nest predation and nest sites: new perspectives on old patterns. BioScience 43(8):523-532.

Martin, T. E., and J. R. Karr. 1986. Patch utilization by migrating birds: resource oriented? Ornis Scandinavica 17: 165-174.

Matheson J.D. and Larson D.W. 1998. Influence of cliffs on bird community diversity. Canadian Journal of Zoology 76:278-287.

Mills, E.D. 1989. Nearctic bird migration and wintering ecology in Belize, Central America. Ph.D. diss., University of Alabama, Tuscaloosa

Monroe, M.S., and G. Ritchison. 2005. Breeding Biology of Henslow's Sparrows on Reclaimed Coal Mine Grasslands in Kentucky. Journal of Field Ornithology 76 (2):143-149.

Moorman, C. E., and D. C. Guynn. 2001. Effects of group-selection opening size on breeding bird habitat use in a bottomland forest. Ecological Applications 11:1680-1691.

Mudrick, D.A., Hoosein, M., Hicks, Jr., R.R., and E.C. Townsend. 1994. Decomposition of leaf litter in an Appalachian forest: effects of leaf species, aspect, slope position and time. Forest Ecology and Management 68(2-3):231-250.

Murray, N. L., and D. F. Stauffer. 1995. Nongame bird use of habitat in central Appalachian riparian forests. Journal of Wildlife Management 59:78-88.

Nauertz, E., T. R. Crow, J. Zasada, and R. Teclaw. 2004. Microclimatic variation between managed and unmanaged northern hardwood forests in Upper Michigan, USA. GTR NC-236. U.S. Department of Agriculture, Forest Service, North Central Research Station, St. Paul, Minnesota, USA.

Newell, F. L. 2010. A bird's eye view of the forest: how does canopy openness affect canopy songbirds. Master's Thesis, The Ohio State University, Columbus, Ohio, 219 pp.

Nowacki, G.J., and Abrams, M.D. 2008. The demise of fire and „mesophication ${ }^{\text {ee }}$ of forests in the eastern United States. BioScience 58:123-138.

Office of Surface Mining Reclamation and Enforcement. 2008. Surface Mining Control and Reclamation Act of 1977 (Public Law 95-87). U.S. Department of Interior, Washington, D.C., USA. 
Pagen, R.W., Thompson, F.R., Burhans, D.E., 2000. Breeding and post-breeding habitat use by forest migrant songbirds in the Missouri Ozarks. Condor 102(4):738-747.

Paton, R. A., J. A. Deane, E. Kohl, R. R. Krause, D. E. Richter, and G. Soine. 1970. Tree planting guide for the reclamation of strip mine lands in Ohio. Ohio Reclamation Association Technical Bull. No. 70-1.

Patton, L.L. 2007. Comparative ecology of the Golden-winged Warbler and Blue-winged Warbler on reclaimed mines in southeastern Kentucky. Master"es Thesis, University of Kentucky, Lexington, KY. 164 pp.

Potter, H.S., S. Weitzman, and G.R. Trimble Jr. 1951. Reforestation of strip-mined lands. Station Paper NE-43. Upper Darby, PA: U.S. Department of Agriculture, Forest Service, Northeastern Forest Experiment Station. 28 pp.

Rice, J.C. 1974. Competitive and social interaction between two interspecifically territorial vireos (Aves: Vireonidae). Ph.D. diss., Univ. of Toronto, Toronto, ON.

Riley, C. V. 1975. Ecosystem development on coal surface-mined lands, 1918-75. p. 303-337. In J. Cairns, K.L. Dikson, and E.E. Herricks (ed.) Recovery and Restoration of Damaged Ecosystems. International Symposium on the Recovery of Damaged Ecosystems. Blacksburg, VA, 23-25 March 1975.

Robinson, S. K. 1981. Social interactions and ecological relations of Philadelphia and Red-eyed Vireos in a New England forest. Condor 83:16-26.

Rodewald, A. D. 2002. Nest predation in forested regions: landscape and edge effects. The Journal of Wildlife Management, 66(3):634-640.

Rodewald, A. D. 2004. Nest searching cues and studies of nest-site selection and nesting success. Journal of Field Ornithology, 75(1):31-39.

Rodewald, A. D., and R. H. Yahner. 2001. Avian nesting success in forested landscapes: influence of landscape composition, stand, nest-patch microhabitat, and biotic interactions. The Auk, 118(4):1018-1028.

Rodewald, A. D. and M. D. Abrams. 2002. Floristics and avian community structure: implications for regional changes in eastern forest composition. Forest Science 48: 267-272.

Rodrigue, J.A. 2001. Woody species diversity, forest and site productivity, stumpage value, and carbon sequestration of forests on mined lands reclaimed prior to the passage of the surface mining control and reclamation act of 1977. Master ${ }^{\text {re }}$ s Thesis, Virginia Polytechnic Institute and State University, Blacksburg, VA, 315 pp. 
Rodrigue, J.A., and J.A. Burger. 2002. Forestry productivity and values for pre-SMCRA mined land. Paper 3-1, in: K. Vories (ed.). Proceedings, Market-Based Approaches to Mined Land Reclamation and Reforestation: A Technical Interactive Forum. U.S. Office of Surface Mining, Mid-Continent Region.

Rosenberg, K.V., and R. Dettmers. 2004. Partners in Flight landbird conservation plan: physiographic area 22: Ohio Hills. 58 pp.

Runkle, J.R. 1982. Patterns of disturbance in some old-growth mesic forest of eastern North America. Ecology 63(5):1533-1546.

Sencindiver, J.C., and J.T. Ammons. 2000. Minesoil genesis and classification. p. 595-613. In R. Barnhisel et al. (ed.) Reclamation of drastically disturbed lands. 2nd ed. Agron. Monogr. 41, ASA, CSSA, and SSSA, Madison, WI

Siepielski, A.M., Rodewald, A.D., and R.H. Yahner. 2001. Nest site selection and nesting success of the Red-eyed Vireo in central Pennsylvania. Wilson Bull. 113(3): 302-307.

Showalter, J. M., and J. A. Burger. 2006. Growth of three Appalachian hardwood species in different mine spoil types with and without topsoil inoculation. Pages 1976-2000 in R. I. Barnhiesel (ed.). Proc., 23th Annual Meeting, American Society of Mining and Reclamation. Lexington, KY.

Skousen, J.G., C.D. Johnson, and K. Garbutt. 1994. Natural revegetation of 15 abandoned mine land sites in West Virginia. J. Environ. Qual. 23:1224-1230.

Skousen, J.G., P. Ziemkiewicz and C. Venable. 2006. Tree recruitment and growth on 20-yearold, unreclaimed surface mined lands in West Virginia. International Journal of Mining, Reclamation and Environment. 20(2):142-154.

Skousen, J.G., J. Gorman, E. Pena-Yewtukhiw, J. King, J. Stewart, P. Emerson, and C. Delong. 2009. Hardwood tree survival in heavy ground cover on reclaimed land in West Virginia: mowing and ripping effects. Journal of Environmental Qualtiy 38:1400-1409.

Smith, R. and M. Dallman. 1996. Forest gap use by breeding Black-throated Green Warblers. Wilson Bulletin 108:588-591.

Southern, W.E. 1958. Nesting of the Red-eyed Vireo in the Douglas Lake region, Michigan. Jack-Pine Warbler 36:105-130 and 185-207.

Stauffer, D. E, and L. B. Best. 1980. Habitat selection by birds of riparian communities: evaluating effects of habitat alterations. Journal of Wildlife Management 44:1-15.

Summerville, K. S., T. O. Crist, J. K. Kahn, and J. C. Gering. 2003. Community structure of arboreal caterpillars within and among four tree species of the eastern deciduous forest. Ecological Entomology 28:747-757. 
Summerville, K.S., and T.O. Crist. 2008. Structure and conservation of lepidopteran communities in managed forests of northeastern North America: a review. The Canadian Entomologist 140:475-494.

Swift, B. L., J. S. Larson, and R. M. DeGraaf. 1984. Relationship of breeding bird density and diversity to habitat variables in forested wetlands. Wilson Bull. 96:48-59.

Thurman, N.C., and Sencindiver, J.C. 1986. Properties, classification, and interpretations of minesoils at two sites in West Virginia. Soil Science Society of America Journal 50:181186.

Vega Rivera, J. H., Rappole, McShea, W. J., and C. A. Haas. 1998. Wood Thrush postfledging movements and habitat use in northern Virginia. Condor 100:69-78.

Villard, M.A. 1998. On forest-interior species, edge avoidance, area sensitivity, and dogmas in avian conservation. Auk 1(15):801-805.

Vitz, A. C., and A. D. Rodewald. 2010. Movements of fledgling Ovenbirds (Seiurus aurocapilla) and Worm-eating Warblers (Helmitheros vermivorum) within and beyond the natal home range. Auk 127:364-371.

Wade, G. L. 1989. Grass competition and establishment of native species from forest soil seed banks. Landscape and Urban Planning 17:135-149.

Walker, L.R., and F.S. Chapin, III. 1987. Interactions among processes controlling successional change. Oikos:131-135.

Weakland, C.A., and P.B. Wood. 2005. Cerulean Warbler (Dendroica cerulea) microhabitat and landscape level habitat characteristics in southern West Virginia in relation to mountaintop valley/fills. Auk 122(2):497-508.

Weishampel, J. F., Drake, J. B., and A. Cooper. 2007. Forest canopy recovery from the 1938 hurricane and subsequent salvage damage measured with airborne LiDAR. Remote Sens. Env. 109:142-53.

Williamson, P. 1971. Feeding ecology of the Red-eyed Vireo (Vireo olivaceus) and associated foliage-gleaning birds. Ecological Monographs 41:129-152.

Wood, P.B., Bosworth, S.B., Dettmers, R., 2006. Cerulean warbler abundance and occurrence relative to large-scale edge and habitat characteristics. Condor 108(1):154-165.

Wood, P.B., J.W. Edwards, and C.A. Weakland. 2001. Terrestrial vertebrate (breeding songbird, raptor, small mammal, herpetofaunal) of forested and reclaimed sites. Final report submitted to EIS steering committee. Morgantown, West Virginia. 149 pp. 
Wray, T., Strait, K.A., and R. C. Whitmore. 1982. Reproductive success of grassland sparrows on a reclaimed surface mine in West Virginia. Auk 99(1):157-164.

Yahner, R. H. 1986. Structure, seasonal dynamics, and habitat relationships of avian communities in small even-aged for est stands. Wilson Bulletin 98:61-82.

Yahner, R.H., and J.C. Howell. 1975. Habitat use and species composition of breeding avifauna in a deciduous forest altered by strip mining. Journal of the Tenn. Acad. of Science 50(4): $142-147$.

Zeleznick, J.D., and J.G. Skousen. 1996. Survival of three species on old reclaimed surface mines in Ohio. West Virginia Agricultural and Forestry Experiment Station, Scientific Article \#2534. 


\section{Chapter 2}

AVIAN ASSEMBLAGES AND RED-EYED VIREO NEST SURVIVAL WITHIN MINELAND FOREST 


\section{ABSTRACT}

Given that avian use of mineland forest has gone largely unstudied, I initiated research to examine patterns of bird species composition within pre-SMCRA mineland forest and reference (unmined) forest in relation to habitat structure and composition. I also contrasted nest survival of Red-eyed Vireos (Vireo olivaceus) breeding within mineland and reference forest. Line transect surveys and nest monitoring were done in New River Gorge National River in 2011. Ordination of avian assemblages using non-metric dimensional scaling (NMDS) showed clear discrimination between mineland and reference assemblages. Linear and surface fitting of habitat variables showed strong correlations between the ordination and groundcover gradients, but generally non-significant relationships for gradients describing forest structure. Mineland assemblages were associated with lower levels of litter cover and depth and also had lower abundance of Ovenbirds (Seiurus aurocapillus). Compared to reference assemblages, mineland assemblage structure was more variable suggesting a wider gradient in forest structure on minelands. Within mineland forest, edaphic conditions/disturbances were likely influential in creating spatial heterogeneity in forest structure. However, nest survival for Red-eyed Vireos was similar within mineland and reference forest and overstory cover and vertical foliage density had minimal effect on nest survival. Classification tree modeling using forest type as the response variable indicated that reference nest sites were characterized by greater subcanopy cover and higher densities of trees in the $8-23 \mathrm{~cm}$ size class than mineland nest sites. Results from this study indicate that forest bird assemblages may be structured differently in the absence of heavy-seeded tree species on minelands.

\section{INTRODUCTION}

Post-mining land use has varied greatly since surface mining was first introduced. Prior to the Surface Mining Control and Reclamation Act (SMCRA) in 1977, coal surface mining in Appalachia generally followed the "shoot and shove" method for extraction resulting in an exposed highwall, bench-land along its face, and an outslope comprised of loose spoil that had been pushed below. SMCRA required that mine operators "backfill, compact, and grade in order to restore the approximate original contour (AOC) of the land with all highwalls, spoil piles, and depressions eliminated" (Office of Surface Mining Reclamation and Enforcement 2008). Mine companies, dozer operators, and regulatory agencies responded with expectations of a uniformly 
smooth post-mining landscape. In the decades that followed, surface mines were generally reclaimed to pastureland dominated by exotics and stress-tolerant species (Burger et al. 2002, Burger et al. 2005, Showalter and Burger 2006). The traditional post-SMCRA post-mining environment is one in which minesoils are severely compacted from immoderate grading, unweathered materials contribute heavily to the growth medium, and aggressive groundcovers inhibit native species colonization (Burger et al. 2002). Under these conditions, forest development is arrested and, through their persistence as degraded, seral communities, surface mines contribute to forest fragmentation (Wade 1989, Johnson and Skousen 1995, Burger and Zipper 2009). Within landscapes that are fragmented by traditionally reclaimed surface mines, forest patches are smaller and forest cover on the landscape scale is reduced (Wickham et al. 2007). As a result, forest songbirds that require large, continuous blocks of forest are negatively affected (Wood et al. 2006).

The Appalachian Regional Reforestation Initiative (ARRI) was established by the Office of Surface Mining in 2004 with the primary objective of encouraging surface mine reforestation through a method termed the Forestry Reclamation Approach (FRA). The Forestry Reclamation Approach is a series of field-tested guidelines directed at advancing forest succession on minelands (Burger and Fannon 2009, Skousen et al. 2009). Components of this approach include creating an uncompacted growth medium in which hardwoods are capable of exhibiting normal survival and growth and seeding non-aggressive groundcovers which do not completely inhibit forest plant invasion (Burger et al. 2005).

Pre-SMCRA abandoned minelands contain areas of uncompacted minesoils on which hardwood forest has developed in the absence of aggressive groundcovers. The pre-SMCRA minelands used in this study were not planted and consequently are dominated by pioneer species. Despite potential differences in tree species composition, study of the relationship between habitat structure and avian assemblage composition within pre-SMCRA mineland forest could provide insight into the species assemblages that future reforestation efforts might yield. Study of the reproductive success of forest songbirds within pre-SMCRA mineland forest may provide some indication as to whether this habitat is capable of sustaining breeding populations of canopy-nesting songbirds.

The objectives of this study were to 1) examine patterns in avian assemblage structure within mined and reference forest and to link the avian assemblage response to variables 
describing habitat structure and composition, and 2) contrast nest survival of Red-eyed Vireos (Vireo olivaceus) breeding within mineland forest and unmined oak-hickory forest.

\section{METHODS}

\section{Study area}

The study area, located atop the New River Plateau within New River Gorge National River in southern West Virginia, included pre-SMCRA abandoned minelands and adjacent unmined sites (hereafter reference forest) (Appendix A). Forest cover is largely unfragmented and of the oak-hickory type. White (Quercus alba), chestnut (Quercus prinus), scarlet (Quercus coccinea), and black oak (Quercus velutina) comprised the predominant canopy species. Yellow poplar (Liriodendron tulipifera), red maple (Acer rubrum), and black birch (Betula lenta) were predominant within minelands. Elevations within the study area are 550-670 m. Soils primarily consist of silt loams and are stony, shallow, and moderately well-drained (USDA 1975).

I selected pre-SMCRA minelands using the following criteria: loose-dumped spoil was placed in ridges and mounds atop benches and also within outslopes, the mineland stand was continuous, mature hardwood forest, the mineland canopy obscured the edge once created by the highwall, and recent off-road vehicle use was not evident. I also chose minelands that were relatively wide (80-100 m wide on average) in order for avian use to bear stronger relation to habitat structure within the mineland patch. The relative expansiveness of pre-SMCRA minelands atop the New River Plateau is an outcome of the moderate terrain that allowed for deeper coal extraction.

Based on aerial photos taken in 1945 (Appendix B), mineland stands were 60-65 years old. Reference stands primarily originated during extensive clearcutting at the turn of the century (Brooks 1910), but also included stands that were closer in age to mineland stands. The latter were abandoned homesteads and a former mining company town that existed as early successional vegetation at the time the 1945 photos were taken.

\section{Avian assemblage structure and habitat relationships}

Across the three study sites, I established 28 fixed-width line transects (14 mined and 14 reference) within four pre-SMCRA abandoned minelands and adjacent, reference forest (Fig. 1 and 2). I used fixed-width line transects because mines were configured linearly with dimensions 
that were generally consistent with a transect width of $50 \mathrm{~m}$ on each side of the line. Line transects also were preferable because in some situations they may yield more detections per unit of time (Bollinger et al. 1988, Buckland et al. 2001). Additionally, the greater survey coverage associated with line transects relative to point transects is thought to limit potential bias from evasive bird movement (Buckland et al. 2001). All transects were $250 \mathrm{~m}$ in length and sampled the available habitat (mineland or reference forest) within $50 \mathrm{~m}$ strips on each side of the line.

Transect layout was accomplished in ArcGIS using a 1-meter Digital Elevation Map (DEM) in which mineland boundaries were clearly evident. I placed the first transect within each discontinuous mineland using a random start point $(0-50 \mathrm{~m})$ measured from the widest point along the northern or eastern edge of each mine (Gates 1979, Buckland et al. 2004). The starting points of subsequent transects were then located $200 \mathrm{~m}$ from the closest point of the previous transect (Bibby et al. 1992). Mineland transects were generally located along the center of the long axis orientation of mines and bent according to mine configuration. In some instances where mine width exceeded $100 \mathrm{~m}$, I oriented transects to maximize their number within the mine.

I placed reference transects to maximize their number within stands of mature, oakhickory forest. In order to follow the general orientation of mineland transects, I attempted to orient reference transects to parallel the dominant contour of the land. I placed each transect 200 $\mathrm{m}$ from adjacent transects at their closest point. I also located reference transects $\geq 150 \mathrm{~m}$ from mines and $\geq 50 \mathrm{~m}$ from the rim of the New River Gorge. I established reference transects as straight lines to facilitate line navigation and accuracy in distance estimation. This contrasted with the bent line orientation of mineland transects. However, mined transects had the benefit of highwall and outslope features in orienting the observer and defining the survey strip.

Bird surveys. In 2011, I conducted transect surveys between May 16 and June 2 from a half hour after sunset to 1030 , coinciding with peak singing. I surveyed each transect over a 25 minute period (Ralph et al. 1993). I flagged transects every $50 \mathrm{~m}$ to facilitate navigation and to ensure that equal survey effort was allotted to each section of a transect. Birds detected within 50 $\mathrm{m}$ of the line were recorded. On mineland transects, I recorded only individuals detected within the boundaries of the mine (e.g. from the base of the highwall to the bottom of the outslope). Sections of minelands that were $<100 \mathrm{~m}$ wide resulted in small differences in the area of habitat surveyed relative to reference transects. Reference transects surveyed 2.5 ha, whereas the mean 
survey area for mineland transects was $2.21 \pm 0.16$ ha (mean \pm SD). All analyses accounted for variation in survey area (see below).

I used a laser rangefinder to estimate the perpendicular distance to each bird detected within $50 \mathrm{~m}$ of the center line. Flyovers were not recorded. I plotted detections within 25 and 50 $\mathrm{m}$ distance bands on a map of each transect. Maps of mineland transects delineated the boundaries of outslope, bench, and highwall features. I surveyed each transect twice and used a species ${ }^{e e}$ maximum count between the two visits for analyses.

Habitat sampling. I sampled habitat structure and composition within four, 0.04 ha circular plots per transect using methods similar to Wood et al. (2001) that were modified from James and Shugart (1970) and the Breeding Bird Research Database Program (BBIRD; Martin et al. 1997). I located plots at a random distance $(0-30 \mathrm{~m})$ perpendicular to 50, 100, 150, and $200 \mathrm{~m}$ intervals along transects. Plots were established on alternating sides of the line with the initial side chosen at random. I identified all trees $>8 \mathrm{~cm}$ diameter at breast height $(\mathrm{dbh})$ to species and measured dbh. I tallied all vines that reached the canopy on measured trees and counted all snags $>8 \mathrm{~cm}$ dbh and $>8 \mathrm{~m}$ tall. Within each plot, I established two, $22.6 \mathrm{~m}$ perpendicular transects. Using an ocular tube and sighting along the tube serosshairs, I estimated vertical foliage density at a total of 20 points, located $2 \mathrm{~m}$ apart along the perpendicular transects. I recorded the presence or absence of live foliage in the crosshairs at heights of 0.5-3 m, >3-6 m, >6-12 m, >12$18 \mathrm{~m},>18-24 \mathrm{~m}$, and $>24 \mathrm{~m}$. From these data, I calculated vertical foliage density as the sum of all foliage hits divided by the total number of sighting intervals (120) and then multiplied by 100 . Foliage density also were collapsed into understory $(0-6 \mathrm{~m})$, midstory $(>6-18 \mathrm{~m})$, and overstory $(>18 \mathrm{~m})$ layers.

Additionally at each of the 20 points, I measured leaf litter depth and recorded groundcover type $(<0.5 \mathrm{~m})$ as bareground, forb, litter (leaf litter and downed woody debris), or woody. Within 3 m-radius subplots at the center of each 0.04 ha plot, I estimated shrub, sapling, leaf litter, and downed woody debris cover (logs and stumps $>8 \mathrm{~cm} \mathrm{dbh}$ and $>1 \mathrm{~m}$ in length). Within each subplot, I also identified and counted woody vegetation $0.5-1.5 \mathrm{~m}$ tall and tallied saplings ( $>1.5 \mathrm{~m}$ tall and $<8 \mathrm{~cm} \mathrm{dbh})$ and downed logs. In ArcGIS, I derived mean slope and solar radiation (insolation) values for each transect from a 1 meter DEM. I used solar radiation (expressed as watt hours $/ \mathrm{m}^{2}$ over the course of a year) as a site-productivity metric in place of aspect because it takes into account slope position in addition to aspect. 


\section{Nest survival of Red-eyed Vireos}

Red-eyed Vireo was chosen as the focal species because they were by far the most abundant species within mineland sites and were found in similar densities within reference forest. This was important in terms of finding enough nests to reliably estimate nest survival. Additionally, Red-eyed Vireo territories are relatively compact; territory size for Red-eyed Vireos breeding on the Monongahela National Forest, West Virginia, was $0.39 \pm 0.16$ ha (mean \pm SD) (Marshall and Cooper 2004). Thus, territory sizes and vireo density reflected use of mineland forest and placed vireos and their nests subject to structural conditions and food resources within this relatively narrow habitat.

I monitored Red-eyed Vireo nests within three reference and three mineland plots (Fig. 3). Reference plots were located $>100 \mathrm{~m}$ from mines and were 5.4-36.4 ha in size (Fig. 5). Mineland plots were 8.8-20.8 ha. I monitored nests every 3-5 days initially and every 1-2 days as fledging approached (Martin and Geupel 1993). To determine nest fate among nests in which inactivity was consistent with reaching or approaching (within 2 days of) predicted fledge dates, I attempted to aurally or visually observe fledglings or adults feeding fledglings. A nest was considered successful if it fledged at least one nestling.

I sampled vegetation within 0.04 ha plots centered at vireo nests following methods described earlier. Additional data collection included measurements of nest height, height of the nest tree, height of the nearest tree in the dominant crown class (tree with a crown that projects above the general canopy layer), and the distance from the nest to both the bottom and top of the canopy, all of which were taken using a clinometer. I also recorded the distance to the nearest canopy gap and the type of gap (edaphic, snag, or treefall). Gaps were defined as having a long axis diameter greater than $5 \mathrm{~m}$ (Pickett and White 1985) with an interior maximum canopy height less than half that of the peripheral canopy. Following Lertzman et al. (1996), edaphic gaps were the product of soil, topographic, or geomorphic features.

\section{ANALYSES}

\section{Avian assemblage structure and habitat relationships}

I used non-metric multidimensional scaling (NMDS) to visualize patterns in avian assemblage structure between mineland and reference forest and to link habitat gradients to 
assemblage pattern. In NMDS, ordination is based upon preservation of the original rank order of between sample distances derived from a dissimilarity matrix (Clarke and Green 1988, Clarke 1993). In using rank order distances, NMDS avoids the linear distribution assumption (Clarke and Green 1988). In addition, NMDS is an unconstrained ordination technique and therefore designed for the purpose of linking patterns in assemblage structure to observed habitat gradients (Oksanen et al. 2009). Locations of assemblages in the multidimensional space are determined through multiple iterations such that stress is minimized (Clarke and Green 1988). Stress is a measure of goodness of fit between plotted and true rank order distances from the original distance matrix (Clarke and Green 1988).

NMDS was conducted using the ,vegan" package (Oksanen et al. 2009) within Program R 2.12.1 (R Development Core Team 2010). Within the species matrix, observations were entered as detections $\mathrm{ha}^{-1}$ rather than raw counts and species detected on $\leq 2$ transects were excluded (Preston and Harestad 2007, Chizinski et al. 2011). Ordination was performed using the metaMDS function and a Bray-Curtis dissimilarity matrix. Data were standardized using the Wisconsin double standardization method and square-root transformed to increase the relative importance of less abundant species. Multiple random starts (20/ordination) were performed to avoid becoming trapped in local minima (the iterative process stalling at a stress value that actually can be further reduced) (McCune and Grace 2002). NMDS was conducted in dimensions 2-6. The stress of NMDS ordinations was evaluated against their dimensionality via a screeplot to determine the appropriate dimensionality for display and statistical testing. The location of the sample as within mined $(\mathrm{M})$ or reference $(\mathrm{R})$ forest was overlaid and species were ordinated by their averaged weighted scores. Habitat variables were correlated to ordinations using vector and surface fitting. For each habitat variable, I used the mean value of the four replicate plots sampled along each transect. Vector fitting allowed for visual interpretation of the strength and direction of the variable-ordination relationship. The strength of the variableordination relationship was statistically assessed using $r^{2}$ and $p$-values derived from 999 permutations. Vector fitting assumes a linear relationship between the variable and the ordination. Because this is often not the case, general additive models (GAM) were used to produce surface fitting contours within the NMDS plot for visual and statistical interpretation of environmental gradients (Oksanen et al. 2009). 
I used the adonis function (,vegan "package; Oksanen et al. 2009) to test for statistical differences between mined and reference assemblages. This function performs a multivariate analysis of variance through partitioning of the sums of squares in a distance matrix in relation to a factor and using $F$-tests from permutations of the data to determine the level of statistical significance (Oksanen et al. 2009). I used the adonis method rather than analysis of similarities (ANOSIM) because the adonis method is generally considered more robust than ANOSIM (Oksanen et al. 2009). I used a Bray-Curtis dissimilarity matrix and specified that permutations (999) occurred within sites but not across sites (Oksanen et al. 2009).

A mean dissimilarity dendrogram was then used to graphically display mean betweengroup and within-group dissimilarity. To determine the appropriate linkage method, I calculated cophenetic correlations between the original Euclidian distance matrix and a Bray-Curtis distance matrix using both "average" and "single" linkage methods (Oksanen et al. 2009). I used the average linkage method because this linkage in combination with a Bray-Curtis metric produced a higher cophenetic correlation (0.43) than did the single linkage method (0.39).

Within the mean dissimilarity dendrogram, vertical lines indicate mean within-cluster dissimilarity; longer lines equate to lower mean dissimilarity (Oksanen et al. 2009). The horizontal line indicates mean between-group dissimilarity (Oksanen et al. 2009).

Using generalized linear modeling (GLM), I tested for differences between reference and mineland assemblages for species richness, overall abundance, and abundance within foraging, nesting, and habitat guilds. All analyses included site as a fixed effect and the area of the transect as an offset. The offset is a term in Poisson and negative binomial regression that allows one to account for differences in exposure or intensity without transforming a raw count into a rate or a density (Zuur et al. 2009). I evaluated models for overdispersion using a Poisson GLM and an associated dispersion parameter. Based on the absence of overdispersion in all models, I determined a Poisson distribution was appropriate for these analyses (Zuur et al. 2009). Statistical significance was assessed via an analysis of deviance test in which the difference in deviance approximately follows a chi-square distribution with 1 degree of freedom (Zuur et al. 2009). Foraging and nesting guilds were adapted from Ehrlich et al. (1988) and Canterbury et al. (2000) (Appendix C). I placed species into habitat guilds (closed canopy species, broken canopy species, and forest generalists) in the context of the canopy disturbance gradient that exists within the study area (contiguous forest with relatively small areas of broken canopy habitat). 
Due to insufficient sample size, I did not conduct analyses for the shrub-nesting guild. One transect was an outlier (Cook"s distance $>1.0)$ for broken canopy and foliage gleaning species and was removed for those analyses. In addition, I tested for differences in Shannon $\left(H^{\prime}\right)$ diversity between mineland and reference forest using a Gaussian distribution, again including site as a fixed effect. I evaluated all Poisson GLMs graphically to ensure that model residuals were not patterned or indicative of a lack of fit. For Gaussian linear regression modeling, I verified that model residuals met assumptions of normality and homogeneity using residual plots and Bartlette's test for homogeneity. Statistical significance was set at $p<0.05$ for all analyses.

\section{Nest survival of Red-eyed Vireos}

To determine support for the influence of forest type on Red-eyed Vireo nest survival, I used an information-theoretic approach and developed a set of a priori candidate models containing habitat and temporal covariates that I hypothesized to influence the nest survival of vireos (Table 4). I used Akaike"s Information Criterion for small sample sizes $\left(\mathrm{AIC}_{\mathrm{c}}\right)$ to evaluate support for candidate models. For computation of $\mathrm{AIC}_{\mathrm{c}}$, I used the effective sample size as defined in Rotella et al. (2004): $\mathrm{n}=$ the total number of days in which all nests were known to have survived + the number of intervals that ended in failure.

Temporal covariates. Temporal covariates included nest stage, linear julian date, and the quadratic effect of date (date + date $^{2}$ ). I recorded Julian date as the midpoint of the monitoring interval. Linear and quadratic effects of date were included because daily nest survival may vary in concert with patterns in predator activity and abundance across the breeding season and this trend may be non-linear (Grant et al. 2005, Peak 2007, Reidy et al. 2009). Due to insufficient monitoring intervals for which laying was recorded, nest stages were restricted to egg (laying and incubation) and brooding stages. Support for temporal covariates was evaluated prior to modeling habitat effects. Covariates from the most supported temporal model were included in all habitat models (Grant et al. 2005, Reidy et al. 2009).

Habitat covariates. Habitat covariates included forest type (mineland or reference), overstory cover (foliage density above $18 \mathrm{~m}$ ), and vertical foliage density (foliage cover estimated across all canopy layers). Mineland and reference forest may represent a gradient of structural conditions. Consequently, patch level influences on nest survival could come from factors that vary across forest types. Higher vertical foliage density within the nest patch could 
function in reducing the risk of predation through concealment (total-foliage hypothesis) and/or by decreasing the search efficiency of a predator (potential-prey-site hypothesis) (Martin 1994). Research by Marshall and Cooper (2004) suggested that Red-eyed Vireos use foliage density as a structural cue in determining the size of a three-dimensional territory with sufficient resources for successful brood rearing. Consequently, foliage density has implications for all aspects of vireo breeding ecology, including nest survival (Marshall and Cooper 2004). Reduced levels of overstory cover could similarly influence nest survival. However, I included both covariates (in separate models) because a high degree of overstory cover does not necessarily indicate a multilayered forest and their influence on nest survival may not be equivalent.

I modeled nest survival as a function of the aforementioned covariates using the logisticexposure method (Shaffer 2004). The basis for this approach is a generalized linear model with a binomial distribution and a logit link function modified to account for the dependence of survival probability on interval length (Shaffer 2004). Because no model received overwhelming support $\left(w_{i} \geq 90 \%\right.$ ), I calculated model-averaged parameter estimates and their unconditional standard errors from a model set comprised of only those models for which there was the most support, models with $\triangle \mathrm{AIC}_{\mathrm{c}}<2$ (Burnham and Anderson 2002). From these estimates, odds ratios and their $95 \%$ confidence intervals were calculated as a means of interpreting the strength of an effect on the daily survival rate (Shaffer and Thompson 2007). The percentage change in the odds of nest survival for a one-unit change in a continuous covariate is calculated by subtracting 1 from the odds ratio and multiplying this value by 100 (Allison 1999).

Daily survival rates for the covariate of interest were derived from model-averaged parameter estimates and their unconditional standard errors by holding values for other covariates at their sample means (continuous covariates), target population proportions (nest stage), or proportions giving equal weight for each level of a categorical covariate (forest type) (Shaffer and Thompson 2007). Proportions used to weigh individual levels of nest stage were based on a 26.5 day nesting period, a 15.5 day laying and incubation stage, and an 11 day nestling stage. I used 26.5 days as the average length of the nesting cycle within the study area because the mean nesting period for all nests monitored from first egg laid through fledging was 26.3 days $(\mathrm{n}=7)$. For continuous covariates, I estimated daily survival rates for values spanning the observed range of the covariate. Logistic exposure models were fit using PROC GENMOD (SAS Institute 2004). The global model was evaluated for goodness-of-fit using the Hosmer and 
Lemeshow method (Hosmer and Lemeshow 2000) and for multicollinearity using tolerance values (Allison 1999).

I used a classification tree to describe variation in forest structure between mineland and reference nest patches. To explore variation in a response variable, classification trees use explanatory variables to recursively partition the data into subsets in which homogeneity in the response variable is maximized and the total sums of squares minimized at each split (Dee ath and Fabricius 2000, De ath 2002). Classification trees are a nonparametic technique; they use the rank order of explanatory variables (De ath and Fabricius 2000). I modeled the classification tree from data collected within 0.04 ha plots centered on each nest and restricted explanatory variables to those describing forest structure within the nest patch. I used the ,mvpart package within Program R 2.12.1 (R Development Core Team 2010). I used 45 (the nest sample size), 10fold cross-validations, to select the smallest tree with an estimated error within 1-SE of the minimum cross-validation error (Breiman et al. 1984, De ath and Fabricius 2000). Cross validation error is the best measure of the predictive accuracy of the tree (De ath 2002). Values near one indicate a tree with poor predictive ability and a value of zero is representative of a perfect predictor (De ath 2002).

\section{RESULTS}

\section{Avian assemblage structure and habitat relationships}

Forest structure and avian community summary. White, chestnut, scarlet, and black oak were the predominant canopy species in reference stands (Fig. 4, Appendix D). Mineland stands were dominated by yellow poplar, red maple, and black birch. Diameter distributions for mineland and reference stands indicated significantly greater numbers of trees in the $8-18 \mathrm{~cm}$ size class within reference forest and a consistent pattern of slightly greater tree density in all size classes $>18 \mathrm{~cm}$ within mineland forest (Fig. 5). Mean basal area for mineland transects was $34.1 \mathrm{~m}^{2} \mathrm{ha}^{-1}(95 \% \mathrm{CI}=31.0,37.1)$ compared to $29.1 \mathrm{~m}^{2} \mathrm{ha}^{-1}(95 \% \mathrm{CI}=27.6 .04,30.5)$ for reference transects (Table 1). There was greater variation in mineland basal area indicating a wider gradient in canopy openness (Fig. 6).

I detected a total of 34 species, 32 on mineland transects and 27 on reference transects (Table 2). The most abundant species along both mineland and reference transects was Red-eyed Vireo, accounting for $36 \%$ and $31 \%$ of the total count within each forest type, respectively. 
Avian assemblage structure. Within the screeplot of ordination stress versus dimensionality, no clear "elbow" was evident in the decline in stress. Stress for the 3dimensional NMDS solution was 15.3 (two convergent solutions after 6 runs). Because stress values less than 20 usually indicate reliability for interpretation (Clarke 1993), samples were plotted within the first two dimensions of the 3-dimensional NMDS solution (Figure 7).

NMDS ordination showed clear discrimination between mineland and reference assemblages (Fig. 7). Ovenbird (Seiurus aurocapillus), Eastern Wood-Pewee (Contopus virens), Blue-headed Vireo (Vireo solitarius), Wood Thrush (Hylocichla mustelina), Acadian Flycatcher (Empidonax virescens), Great Crested Flycatcher (Myiarchus crinitus), and White-breasted Nuthatch (Sitta carolinensis) separated reference from mineland assemblages. Mineland assemblages were spread widely along NMDS axis 1 with a band of species positioned in a stretched pattern along their periphery indicating that these species were not strongly interrelated within mineland assemblages. The inconsistent pattern of relationships among species within mineland assemblages is likely a reflection of variation in habitat structure, low sample sizes, the discontinuous nature of the habitat, and the association of several of these species with isolated patches of disturbed forest.

Species which contributed little to the overall dissimilarity between forest types were Red-eyed Vireo, Scarlet Tanager, and several bark-foraging species. Bark-foraging species were located in a band across the center of the ordination and included (Fig. 7) Black-and-white Warbler (Mniotilta varia), Hairy Woodpecker (Picoides villosus), Pileated Woodpecker (Dryocopus pileatus), Red-bellied Woodpecker (Melanerpes carolinus), and Yellow-throated Vireo (Vireo flavifrons), the latter species also relying on foliage-gleaning.

Several groundcover variables were strongly correlated with the ordination (Table 2). In general, surface fitting strengthened groundcover-ordination relationships (Table 2) suggesting non-linear correlations (Oksanen et al. 2009). Litter cover and litter depth increased in the direction of reference assemblages in which two ground-foraging species, Ovenbird and Wood Thrush, were discriminating components (Fig. 7 and 8). Forb cover, bareground cover, snag density, and canopy vine density increased in the direction of mineland assemblages (Fig. 7). Tree diversity $\left(H^{\prime}\right)$ increased in the direction of reference assemblages. Canopy cover and structural variables had weaker correlations with the ordination and tended to be non-significant (Table 2). 
The strength of the surface fit for the shrub density gradient (Table 2) was the result of fitting one mineland transect located on the far right side of the plot (Figure 7). The understory within the forest surveyed by this transect was dominated by dense multiflora rose (Rosa multiflora). Canopy closure was reduced relative to other mineland transects likely as a result of edaphic conditions and the presence of lightly foliated tree species in the canopy, i.e. river birch (Betula nigra) and bigtooth aspen (Populus grandidentata). Consequently, broken canopy species, such as Hooded Warbler (Wilsonia citrina) and American Redstart (Setophaga ruticilla), were characteristic of this assemblage.

The mean dissimilarity analysis indicated higher within-group dissimilarity for mineland forest assemblages echoing the pattern evident in the NMDS ordination (Fig. 9).

The adonis analysis indicated that assemblage structure differed between mineland and reference forest $\left(F_{1,26}=4.38, p=0.001\right)$; between group distances were statistically greater than within group distances. Forest type accounted for only $14 \%$ of the variation in assemblage structure (partial $R^{2}=0.14$ ), an outcome, in part, of high within-group dissimilarity.

Overall relative abundance was similar for reference and mineland forest (Table 3). Species richness and Shannon $\left(H^{\prime}\right)$ diversity also were similar between forest types, but were more variable across mineland transects (Fig 10). Mineland and reference forest had similar abundance of broken canopy and forest generalist species (Fig. 10), but closed-canopy species had greater abundance within reference forest $(p=0.002)$. Mineland and reference forest had similar abundance of bark foraging and foliage gleaning species (Fig. 10), while hawking ( $p=$ $0.03)$ and ground gleaning species $(p=0.02)$ had greater abundance within reference forest. Abundance within nesting guilds was similar between forest types (Fig. 10).

\section{Nest survival of Red-eyed Vireos}

I monitored 45 Red-eyed Vireo nests in 2011, 21 within mineland forest and 24 within reference forest. Using the formula from Rotella et al. (2004), the effective sample size for computing $\mathrm{AIC}_{\mathrm{c}}$ was 597. The Hosmer and Lemeshow (2000) goodness-of-fit test indicated that the global model fit the data adequately $\left(\chi^{2}=5.78, \mathrm{df}=8, p=0.67\right)$. Tolerance values for variables within the global model were all $\geq 0.65$, indicating that multicollinearity was not a concern (Allison 1999). 
Model selection for temporal effects found the most support for a model that included solely the effects of nest stage $\left(w_{i}=0.38\right)$ (Table 4$)$. Therefore, I included nest stage in all habitat models.

No habitat model received overwhelming support and all models, with the exception of the global model, had values for $\Delta \mathrm{AIC}_{\mathrm{c}} \leq 4$ indicating some level of empirical support for each (Burnham and Anderson 2002) (Table 4). This is in part due to the inclusion of nest stage in all habitat models; the best-fitting habitat model contained only the effect of nest stage. Other supported models with $\Delta \mathrm{AIC}_{\mathrm{c}} \leq 2$ included forest type, overstory cover, and vertical foliage density models. Models with greater complexity $(k \geq 4)$ tended to have less support.

Model-averaged parameter estimates and unconditional standard errors were derived from a model set (habitat models with $\Delta \mathrm{AIC}_{\mathrm{c}} \leq 2$ ) that excluded the three least supported models. Daily survival was higher during laying and incubation stage $(0.961, \mathrm{CI}=0.935,0.977)$ than during the nestling stage $(0.923, \mathrm{CI}=0.882,0.951)$ (Fig. 11). The odds ratio for nest stage indicated that the odds of nest survival were 51\% lower during the nestling stage than during the laying and incubation stage, but the $95 \% \mathrm{CI}$ for the odds ratio narrowly overlapped 1.0 (Table 5).

Overall nesting period survival was $0.246(\mathrm{CI}=0.132,0.379)$. Period survival for mineland and reference nests, respectively, were $0.257(\mathrm{CI}=0.126,0.411)$ and $0.234(\mathrm{CI}=$ $0.114,0.381$ ) (Fig. 11). Relative to reference nests, the odds of daily nest survival were $7 \%$ greater for mineland nests, but the $95 \%$ CI widely overlapped 1.0 indicating that strength of this effect was low (Table 5). Similarly, odds ratios for overstory cover and vertical foliage density overlapped one indicating minimal influences on nest survival.

Nest patch characteristics. In both mineland and reference forest, vireos placed nests in red maple more than any other tree species (Table 6). Otherwise, nest tree use reflected mesophytic species composition within mineland forest and oak-hickory predominance within reference forest.

The predominant origin of canopy gaps occurring nearest to Red-eyed Vireo nests differed between mineland and reference forest (Table 6). Gaps adjacent to mineland nests $(\mathrm{n}=21)$ were primarily classified as edaphic $(57 \%)$, whereas $75 \%$ of gaps adjacent to reference nests $(n=24)$ had treefall origins. Gaps categorized as edaphic were compacted areas such as old haul roads, depressions in which water was ponded, boulder piles at the base of both outslopes and highwalls, and areas where the absence of mature trees indicated poor physical and chemical 
properties of minesoils. Vireo nests were located closer to canopy gaps in mineland forest (16.2 $\pm 2.7 \mathrm{~m}$; mean $\pm \mathrm{SE}$ ) than within reference forest $(26.0 \pm 4.1 \mathrm{~m})$ (Table 7).

In modeling structural characteristics of nest patches, ten-fold cross-validation using the 1-SE rule resulted in the selection of a four-leaved tree (Fig. 12). This tree explained $85.7 \%$ of the variance and had a misclassification rate of $6.7 \%$ and a cross validation error of 0.569 , the latter indicating that the tree was an intermediate predictor. With the exception of the split based on canopy vine density, partitioning is through variables that separate reference nest patches from mineland nest patches on the basis of greater vertical heterogeneity. The first split is based on higher small tree $(8-23 \mathrm{~cm}$ dbh) density within reference nest patches. Individuals within this size class are typically contributing foliage to mid- and subcanopy layers. This split explains the largest proportion of the variance and results in a nearly homogenous subset in its right terminal node in which $75 \%$ of reference nest patches are contained. The second split indicates higher canopy vine density within mineland nest patches. This characteristic represents a potential resource for mineland-breeding vireos in terms of providing nest material and foliage in which to conceal nests. The right node extending from the canopy vine split is in turn partitioned by subcanopy (0-6 m) foliage cover. This split results in a terminal node with a small, homogenous subset of mineland nest patches that had lower $(<12.5 \%)$ subcanopy cover.

\section{DISCUSSION}

\section{Avian assemblage structure and habitat relationships}

The avian mineland assemblage was distinct from the reference assemblage despite the habitat being a narrow continuation of the closed-canopy forest in which it is imbedded. Groundcover gradients were strongly correlated with the NMDS ordination and indicated that mineland assemblages were associated with lower litter cover and depth. Decreased litter cover and depth likely contributed to the lower abundance of Ovenbirds within mineland forest. Breeding ecology studies of Ovenbirds, a ground-nesting and foraging species, have shown positive associations between leaf litter depth and pairing success (Burke and Nol 1998, Rodewald and Yahner 2000) and the selection of nest sites characterized by deeper leaf litter and lower levels of bareground cover relative to randomly selected sites (Burke and Nol 1998).

Tree species composition and mineland topography were likely influential in the lower abundance of Ovenbirds within mineland forest. Within forest dominated by mesophytic species, 
leaf litter and downed woody debris decomposition is typically more rapid (Nowacki and Abrams 2008). Decay is accelerated as a result of the structural characteristics of the leaves and wood belonging to mesophytic species and the cool, moist microclimate existing within the deeply shaded understory of these forests (Mudrick et al. 1994, Nowacki and Abrams 2008, Fox et al. 2010). Consequently, within mineland forest, a near complete dominance by mesophytic tree species was likely an important influence on understory light penetration, temperature, soil moisture, and soil fertility, characteristics which cumulatively were manifested in decreased litter depth and greater forb cover.

Fox et al. (2010) found that Ovenbird, Black-and-white Warbler (Mniotilta varia), and Worm-eating Warbler (Helmitheros vermivorus), all ground-nesting species, were absent from maple dominated stands in which leaf litter depth was lower relative to the oak-dominated stands in which they were present. I did not find ground-nesting species, as a group, to have lower abundance in mineland forest.

In addition to litter characteristics, features of mineland topography, e.g. outslopes and highwalls, may simply displace Ovenbirds. Characteristics of the forest floor along outslopes, including their steepness (typically $>40 \%$ slope) and a high proportion of boulder and eroded, bareground cover, likely produce poor quality foraging and nesting habitat for Ovenbirds. Ovenbirds generally select territories and nest sites with low to moderate slope steepness (Wenny et al. 1993, Burke and Nol 1998).

I did not find differences in the abundance of bark gleaning or cavity nesting species between mineland and reference forest. Among these species, only White-breasted Nuthatch appeared to separate reference from mineland assemblages in the NMDS ordination. The majority of bark-foraging species were located centrally within the ordination space indicating they contributed little to dissimilarity between forest types. Minelands may receive some use from bark gleaning and cavity nesting species due to an abundance of snags and downed logs. However, these species have relatively large home ranges and the mineland habitat that I surveyed is not isolated from oak-dominated forest. In a comparison of bird communities within maple and oak dominated stands, Rodewald and Abrams (2002) found lower abundance of the bark gleaning guild in maple dominated stands during the three seasons they surveyed: spring, fall, and winter. They attributed this finding to the availability of acorns in oak-dominated forests. 
Relative to reference assemblages, mineland assemblages had higher within-group dissimilarity suggesting a wider gradient in habitat conditions. Basal area was higher, but more variable for mineland transects. Within mineland forest, edaphic conditions/disturbances were likely influential in creating spatial heterogeneity in forest structure. Studies of mineland succession have indicated that the irregular composition of minesoils and the resulting fine-scale variation in spoil acidity, rock fragment composition, and shale content combine to produce spatial and compositional heterogeneity in vegetation development (Game et al. 1982, Skousen et al. 1994).

Correlations between the overall assemblage response and variables that reflect canopy structure were generally non-significant. In part, this is a consequence of a finer scale gradient in forest structure (comparing one even-aged, closed-canopy forest to another), whereas differences in groundcover were comparatively abrupt. Low sample size mineland habitat variation, and the discontinuous nature of the mineland habitat also contributed to difficulty in assessing the relationship between the assemblage response and forest structure.

Forests dominated by yellow poplar and red maple may represent poor-quality foraging and nesting habitat for a number of species. Previous studies have indicated foraging preferences among insectivorous songbirds for oaks and hickories and avoidance of red maple (Gabbe et al. 2002, Rodewald and Abrams 2002, George 2009, Newell 2010). Some forest songbirds may not be adapted for capturing arthropods on red maple foliage due to the length of its petioles and the size of its leaves (Franzreb 1978, Holmes and Robinson 1981, Holmes and Schultz 1988, Rodewald and Abrams 2002). In addition, lepidopteran assemblages may be strongly organized by the dominant canopy species (Summerville and Crist 2008) and, relative to other hardwood species, oaks may host a greater diversity of lepidopteran species (Summerville et al. 2003). Additionally, stands dominated by mesophytic hardwoods typically have higher basal area and, consequently, greater canopy closure compared to oak-dominated stands (Nowacki and Abrams 2008). The higher abundance of hawking species in reference forest, specifically, Great Crested Flycatcher and Eastern Wood-Pewee, was likely in response to lower basal area and greater canopy openness. Opening of the canopy may result in conditions (a warmer understory microenvironment and elevated primary productivity) that favor the growth of flying insect populations (Blake and Hoppes 1986, Smith and Dallman 1996, Gorham et al. 2002, George 2009). In studies of partial harvesting, Eastern Wood Pewees and Great-Crested Flycatchers 
generally responded positively to basal area reductions (Annand and Thompson 1997, Moorman and Guynn 2001, Holmes et al. 2004, Newell 2010).

In mixed-mesophytic forest in Ohio, Eastern Wood-Pewees placed nests in white oak in disproportion to its availability and avoided placing nests in red maple and yellow poplar (Newell 2010). Within mineland stands, reduced inter-crown spacing, predominantly vertical branching, and the tall, clean boles of yellow poplar generally concentrated foliage in the upper canopy (personal observation). Eastern Wood-Pewees as well as other species may not be adapted for nest placement in this type of canopy structure. For Blue-headed Vireos, a species which discriminated reference assemblages, mineland forest may have represented poor quality nesting habitat due to insufficient subcanopy development. Blue-headed Vireos often forage and nest within the lower canopy (Hamel 1992, Meehan 1996, James 1998) and, within central Appalachian forests, may reach greater densities within xeric forest associations relative to more mesic associations (Weakland 2000). Mineland forest had lower sapling density and cover and lower small tree $(8-23 \mathrm{~cm} \mathrm{dbh})$ density compared to the relatively xeric, reference forest. In oakhickory forest in southwestern Virginia, McEvoy et al. (1980) found greater foliage density in the 1-5 m layer within xeric sites relative to mesic sites. In the Great Smoky Mountains, Whitaker (1956) found increasing shrub cover along a moisture gradient from mesic coves to xeric spur ridges. Within xeric sites, greater light penetration through sparser canopies contributed to the increase in shrub cover (Whitaker 1952, 1956).

In general, mineland canopies follow the relatively simple structure that is characteristic of secondary forests (Lorimer 1989, Hart and Grissino-Mayer 2008). Crowns are typically nonoverlapping, but restricted in their breadth by the uniform distribution of adjacent crowns. Dominants are young and, consequently, less frequent gap makers (Lorimer 1989). In response to individual tree mortality, rapid lateral crown expansion limits the duration in which the canopy remains open (Lorimer 1989). However, canopy structure and gap dynamics in mineland forests may differ slightly. Within mineland forest, canopy gaps occurring nearest to Red-eyed Vireo nests were primarily edaphic in origin. Depending on the size of the edaphic disturbance, these gaps may come to represent persistent open space (Lertzman et al. 1996).

Species composition strongly influences stand development through differences in the growth rates and shade tolerance of component species (Gingrich 1967). Reference stands were generally older than mineland stands. However, the comparison of mineland and reference forest 
is one of starkly contrasting tree species composition and distinct developmental pathways. Thus, given the range of mineland and reference stand ages ( $\sim 60-110$ years old), the influence of stand age on forest structure and the avian assemblage response was likely secondary to differences in tree species composition and in the forest floor environment.

\section{Red-eyed Vireo nest survival}

Red-eyed Vireo nest survival was similar within mineland and reference forest. Classification tree modeling indicated that reference nest patches were characterized by greater vertical heterogeneity than mineland nest patches. Despite these differences, I did not find a strong effect of nest patch characteristics on nest survival. In a study of Red-eyed Vireo nest site selection in Pennsylvania, habitat characteristics of nest patches were not indicative of nest fate (Siepielski et al. 2001). Given the nested nature of mineland stands, predator assemblage structure was not likely drastically changed from adjacent reference forest. Across both forest types, the canopy disturbance gradient was relatively narrow and may have been insufficient to produce differences in predator activity or search-efficiency. Forest cover and structure on larger scales may be more influential in terms of structuring predator assemblages and affecting reproductive success (Donovan et al. 1997, Siepielski et al. 2001, Rodewald 2002).

However, I did not expect nest survival to be poor overall given that the study area lies within largely unfragmented forest. Nest survival on my sites $(0.246, \mathrm{CI}=0.132,0.379)$ was much lower in comparison to the Mayfield nest success $(0.430 \pm 0.04 \mathrm{SE} ; \mathrm{n}=126)$ observed by DeCecco et al. (2000) for Red-eyed Vireos breeding on the Monongahela National Forest in southeastern West Virginia. In south-central Ontario, Burke and Nol (2000) found Mayfield nest success to be $0.420 \pm 0.122 \mathrm{SD}(\mathrm{n}=18)$ for Red-eyed Vireos breeding within continuous forest and $0.251 \pm 0.067 \mathrm{SD}(\mathrm{n}=46)$ for vireos breeding within small forest fragments. For these habitats to function as population sources, they determined that 1.9 nesting attempts were necessary for continuous forest stands and 3.9 nesting attempts for small forest fragments.

The heights at which vireos placed nests in both mineland and reference forest were much greater than nest heights reported by other studies and may provide some explanation for the poor overall nest survival that I observed. Mean heights for vireo nests were $18.9 \mathrm{~m} \pm 7.0 \mathrm{SD}$ and $20.7 \mathrm{~m} \pm 5.8 \mathrm{SD}$ within reference and mineland forest, respectively. Studies conducted in the Midwest and in northern hardwoods forest (Lawrence 1953, Southern 1958, Rice 1974, Graber et 
al. 1985) observed mean nest heights within a range of 2.5-4.3 m. Other studies have reported mean nest heights that reflect greater variability; $10.7 \mathrm{~m} \pm 5.8 \mathrm{SD}$ for a study in New Hampshire (Robinson 1981) and 7.0 $\mathrm{m} \pm 5.7 \mathrm{SD}$ for a study in the southeastern West Virginia (DeCecco et al. 2000). The upper-canopy focused nest placement within my study may indicate that neither mineland nor reference forest had sufficient foliage density in the mid- and subcanopy to induce nest placement within these layers. This may have in turn resulted in greater predator searchefficiency and reduced nest concealment.

This study is the first to describe avian assemblages in relation to habitat structure and composition within mineland forest. It is also the first to quantify songbird reproductive success within mineland forest. Sample sizes were low as a consequence of the limited scale of mineland stands and the uncommonness of minelands with relatively wide, uncompacted benches on which mature forests have established naturally. However, this research lends support for the emphasis of the Forest Reclamation Approach in establishing heavy-seeded species on minelands. Within mineland stands, the near complete dominance of mesophytic tree species was likely influential in the lower abundance of Ovenbirds as well as other ground-gleaning, hawking, and closed-canopy species. 


\section{Literature Cited}

Allison, P.D. 1999. Logistic regression using the SAS system: theory and application. SAS Institute, Inc., Cary, NC

Annand, E.M., and F.R. Thompson, III. 1997. Forest bird response to regeneration practices in central hardwood forests. Journal of Wildlife Management 61:159-171.

Bibby, C. J., Burgess, N.D. and D. A. Hill. 1992. Bird census techniques. Academic Press, London.

Blake, J. G. and W. G. Hoppes. 1986. Influence of resource abundance on use of tree-fall gaps by birds in an isolated woodlot. Auk 103:328-340.

Bollinger, E. K., Gavin, T. A., and D. C. McIntyre. 1988. Comparison of transects and circular plots for estimating Bobolink densities. Journal of Wildlife Management 52: $777-786$.

Breiman, L., Friedman, J. H., Olshen, R. A., and C. G. Stone. 1984. Classification and Regression Trees. Wadsworth International Group, Belmont, California, USA.

Brooks, A.B. 1910. West Virginia Geological Survey, Volume Five: Forestry and Wood Industries. The Acme Publishing Company, Morgantown, WV

Buckland, S. T., D. R. Anderson, K. P, Burnham, J. L. Laake, D. L. Borchers, and L.Thomas. 2001. Introduction to distance sampling: estimating abundance of biological populations. Oxford University Press, New York, NY, USA.

Buckland, S. T., D. R. Anderson, K. P, Burnham, J. L. Laake, D. L. Borchers, and L. Thomas. 2004. Advanced distance sampling. Oxford University Press, New York, NY, USA.

Burger, J.A., Mitchem, D.O., and D.A. Scott. 2002. Field assessment of mine site quality for establishing hardwoods in the Appalachians . Pages 226-240 in Proceedings, 2002 National Meeting of the American Society for Mining and Reclamation. Lexington, KY.

Burger, J., Graves, D., Angel, P., Davis, V., and C. Zipper. 2005. The Forestry Reclamation Approach. Forest Reclamation Advisory No. 2. U.S. Office of Surface Mining, ARRI, Washington, DC

Burger, J.A. and A.G. Fannon. 2009. Capability of reclaimed mined land for supporting reforestation with seven Appalachian hardwood species. Pages 176-191 in 26th: National Meeting of the American Society of Mining and Reclamation.

Burger, J. A., and C. E. Zipper. 2009. How to restore forests on surface-mined land. Reclamation guidelines for surface mined land in southwest Virginia series. Powell River Project, Virginia Cooperative Extension. Pub. 460-123. 
Burnham, K.P., and D.R. Anderson. 2002. Model Selection and Multimodel Inference: An Information-Theoretic Approach. Springer-Verlag, New York, New York, USA

Burke, D. M., and E. Nol. 1998. Influence of food abundance, nest-site habitat, and forest fragmentation on breeding Ovenbirds. Auk 115:96-104.

Burke, D. M., and E. Nol. 2000. Landscape and fragment size effects reproductive success of forest-breeding birds in Ontario. Ecological Application 10(6):1749-1761.

Canterbury, G. E., Martin, T. E., Petit, D. R., Petit, L. J. and Bradford, D. F.: 2000. Bird communities and habitat as ecological indicators of forest condition in regional monitoring. Conserv. Biol. 14:544-558.

Chizinski, C.J., Peterson, A., Hanowski, J., Blinn, C.R., Vondracek, B., and Niemi, G. 2011. Breeding bird response to partially harvested riparian management zones. Forest Ecology and Management 261:1892-1900.

Clarke, K. R. 1993. Non-parametric multivariate analyses of changes in community structure. Australian Journal of Ecology 18:117-143.

Clarke, K. R., and R. H. Green. 1988. Statistical design and analysis for a „biological effectse $^{\text {ee }}$ study. Marine Ecology Progress Series 46: 213-226.

De ath, G., and K. E. Fabricius. 2000. Classification and regression trees: a powerful yet simple technique for the analysis of complex ecological data. Ecology 81:3178-3192.

Deeath, G. 2002. Multivariate regression trees: a new technique for modeling speciesenvironment relationships. Ecology 83(4):1105-1117.

DeCecco, J.A., Marshall, M.A., Williams, A.B., Gale, G.A., and R.J. Cooper. 2000. Comparative seasonal fecundity of four Neotropical migrants in middle Appalachia. Condor 102: 653-663.

Donovan, T. M., Jones, P. W., Annand, E. M., and F.R. Thompson, III. 1997. Variation in localscale edge effects: mechanisms and landscape context. Ecology 78:2064-2075.

Ehrlich, P. R., Dobkin, D. S., and D. Wheye. 1988. The Birderes Handbook, Simon and Schuster, New York.

Fox, V.L., Buehler, C.P., Byers, C.M., and S.E. Drake. 2010. Forest composition, leaf litter, and songbird communities in oak- vs. maple-dominated forests in the eastern United States. Forest Ecology and Management 259:2426-2432.

Franzreb, K.E. 1978. Tree species used by birds in logged and unlogged mixed-coniferous forests. Wilson Bulletin 90:221-238. 
Gabbe, A. P., Robinson, S.K., and J. D. Brawn. 2002. Tree-species preferences of foraging insectivorous birds: implications for floodplain forest restoration. Conservation Biology $16: 462-470$.

Game, M., J. E. Carrel, and T. Hotrabhavadra. 1982. Patch dynamics on abandoned surface mines. Journal of Ecology 70(3):707-720.

Gates, C. E. 1979. Line transect and related issues in sampling biological populations. Pages 71154 in Sampling Biological Populations, R. M. Cormack, G. P. Patil, and D. S. Robson (eds), Burtonsville, Maryland: International Cooperative Publishing House.

George, G.A. 2009. Foraging ecology of male Cerulean Warblers and other Neotropical migrants. Ph.D. Thesis, West Virginia University, Morgantown, WV.

Gingrich, S. F. 1967. Measuring and evaluating stocking and stand density in upland hardwood forests of the central states. Forest Science 13:38-53

Gorham, L. E., S. L. King, B. D. Keeland, and S. Mopper. 2002. Effects of canopy gaps and flooding on homopterans in a bottomland hardwood forest. Wetlands 22:541-549.

Graber, J.W., Graber, R.R., and E.L. Kirk. 1985. Illinois birds: vireos. Biol. Notes no. 68. Illinois Nat. Hist. Surv., Urbana.

Grant, T.A., Shaffer, T.L., Madden, E.M., Pietze, P.J., 2005. Time-specific variation in passerine nest survival: new insights into old questions. Auk 122:661-672.

Hart, J.L., and H.D. Grissino-Mayer. 2008.Vegetation patterns and dendroecology of a mixed hardwood forest on the Cumberland Plateau: implications for stand development. Forest Ecol. Management 255:1960-1975.

Holmes, R.T., and S.K. Robinson. 1981. Tree species preferences of foraging insectivorous birds in a northern hardwoods forest. Oecologia 48:31-35.

Holmes, R. T., and J. C. Schultz. 1988. Food availability for forest birds: effects of prey distribution and abundance on bird foraging. Canadian Journal of Zoology 66: 720-728.

Holmes, S.B., Burke, D.M., Elliott, K.A., Cadman, M.D., Friesen, L. 2004. Partial cutting of woodlots in an agriculture-dominated landscape: effects on forest bird communities. Canadian Journal of Forest Research 34(12):2467-2476.

Hosmer, D. W., and S. Lemeshow. 2000. Applied logistic regression. John Wiley and Sons, New York.

James, F. C. and H. H. Shugart. 1970. A quantitative method of habitat description. Audubon. Field Notes 24:727-736. 
James, Ross D. 1998. Blue-headed Vireo (Vireo solitarius), The Birds of North America Online (A. Poole, ed.). Ithaca: Cornell Lab of Ornithology; Retrieved from the Birds of North America Online: http://bna.birds.cornell.edu.bnaproxy.birds.cornell.edu/bna/species/379

Johnson, C.D., and J.G. Skousen. 1995. Minesoil properties of 15 abandoned mine land sites in West Virginia. Journal of Environmental Equality 24:635-643.

Lawrence, L. K. 1953. Nesting life and behavior of the Red-eyed Vireo. Canadian Field Naturalist 67:47-76.

Lertzman, K. P., G. D. Sutherland, A. Inselberg, and S. C. Saunders. 1996. Canopy gaps and the landscape mosaic in a coastal temperate rain forest. Ecology 77:1254-1270.

Lorimer, C.G. 1989. Relative effects of small and large disturbances on temperate hardwood forest structure. Ecology 70(3):565-567.

McCune, B. and J. B. Grace. 2002. Analysis of ecological communities. MjM Software Design, Gleneden Beach, Oregon.

McEvoy, T.J., T.L. Sharik, and D.W. Smith. 1980. Vegetative structure of an Appalachian oak forest in southwestern Virginia. Amer. Midi. Naturalist 103:96-105.

Marshall, M.R., and R.J. Cooper. 2004. Territory size of a migratory songbird in response to caterpillar density and foliage structure. Ecology 85(2):432-445.

Martin, T. E. 1988. Processes organizing open-nesting bird assemblages: competition or nest predation? Evolutionary Ecology 2:37-50.

Martin, T. E. 1994. Nest predation and nest sites: new perspectives on old patterns. BioScience 43(8):523-532.

Martin, T. E., and G. R. Geupel. 1993. Nest-monitoring plots: Methods for locating nests and monitoring success. Journal of Field Ornithology 64:507-519.

Martin, T.E., C. Paine, C.J. Conway, W. M. Hockachka, P. Allen, and W. Jenkins. 1997. BBIRD Field Protocol. USGS, Biological Resources Division, Montana Cooperative Fish and Wildlife Research Unit, Missoula, Montana.

Moorman, C. E., and D. C. Guynn. 2001. Effects of group-selection opening size on breeding bird habitat use in a bottomland forest. Ecological Applications 11:1680-1691.

Mudrick, D.A., Hoosein, M., Hicks, Jr., R.R., and E.C. Townsend. 1994. Decomposition of leaf litter in an Appalachian forest: effects of leaf species, aspect, slope position and time. Forest Ecology and Management 68(2-3):231-250. 
Newell, F. L. 2010. A bird's eye view of the forest: how does canopy openness affect canopy songbirds. Master's Thesis, The Ohio State University, Columbus, Ohio, 219 pp.

Nowacki, G.J., and Abrams, M.D. 2008. The demise of fire and „mesophication ${ }^{e e}$ of forests in the eastern United States. BioScience 58:123-138.

Office of Surface Mining Reclamation and Enforcement. 2008. Surface Mining Control and Reclamation Act of 1977 (Public Law 95-87). U.S. Department of Interior, Washington, D.C., USA.

Oksanen, J., Kindt, R., Legendre, P., O'Hara, B., Simpson, G.L., Solymos, P., Stevens, M. H. H., and $\mathrm{H}$. Wagner. 2009. vegan: community ecology package. $\mathrm{R}$ package version $1.15-2$. $\mathrm{R}$ Foundation for Statistical Computing, Vienna, Austria. (Available from: http://cran.rproject.org/, http://vegan.r-forge.r-project.org)

Peak, R. G. 2007. Forest edges negatively affect golden-cheeked warbler nest survival. Condor 109:628-637.

Petit, D. R., Petit, K. E., and T. C. Grubb, Jr. 1985. On atmospheric moisture as a factor influencing distribution of breeding birds in temperate deciduous forest. Wilson Bulletin 97:88-96.

Pickett, S.T.A., and P.S. White (eds.). 1985. The Ecology of Natural Disturbance and Patch Dynamics. Academic Press, New York, NY.

Preston, M.I., and A.S. Harestad. 2007. Community and species response by birds to group retention in a coastal temperate forest on Vancouver Island, British Columbia. Forest Ecology and Management 243:156-167.

Reidy, J. L., Thompson III, F. R., and R. G. Peak. 2009. Factors affecting Golden-cheeked Warbler nest survival in urban and rural landscapes. Journal of Wildlife Management 73:407-413.

R Development Core Team. 2010. R: A language and environment for statistical computing. R Foundation for Statistical Computing, Vienna, Austria. ISBN 3-900051-07-0, URL http://www.R-project.org.

Ralph, C.J., Geupel, G.R., Pyle, P., Martin, T.E., and D.F. DeSante. 1993. Handbook of field methods for monitoring landbirds. U.S. Dept. Agric. For. Serv. Gen. Tech. Rep. PSWGTR-144.

Reidy, J.L., Thompson III, F.R., and R.G. Peak. 2009. Factors affecting golden-cheeked warbler nest survival in urban and rural landscapes. Journal of Wildlife Management 73:407-413.

Rice, J.C. 1974. Competitive and social interaction between two interspecifically territorial 
vireos (Aves: Vireonidae). Ph.D. diss., Univ. of Toronto, Toronto, ON.

Robinson, S. K. 1981. Social interactions and ecological relations of Philadelphia and Red-eyed Vireos in a New England forest. Condor 83:16-26.

Rodewald, A. D. 2002. Nest predation in forested regions: landscape and edge effects. The Journal of Wildlife Management, 66(3):634-640.

Rodewald, A. D. and M. D. Abrams. 2002. Floristics and avian community structure: implications for regional changes in eastern forest composition. Forest Science 48: $267-272$.

Rodewald, A. D. and R.H. Yahner. 2000. Influence of landscape and habitat characteristics on Ovenbird pairing success. Wilson Bulletin 112(2): 238-242.

Rotella, J.J., Dinsmore, S.J., and J.A. Shaffer. 2004. Modeling nest-survival data: a comparison of recently developed methods that can be implemented in MARK and SAS. Animal Biodiversity and Conservation 27:187-205.

SAS Institute, Inc., 2004. The SAS System for Windows, Version 9.1. SAS Institute Inc., North Carolina, USA.

Siepielski, A.M., Rodewald, A.D., and R.H. Yahner. 2001. Nest site selection and nesting success of the Red-eyed Vireo in central Pennsylvania. Wilson Bull. 113(3):302-307.

Shaffer, T.L., 2004. A unified approach to analyzing nest success. Auk 121:526-540.

Shaffer, T.L., and F.R. Thompson III. 2007. Making meaningful estimates of nest survival with model-based methods. Studies in Avian Biology 34:84-95.

Showalter, J. M., J. A. Burger. 2006. Growth of three Appalachian hardwood species in different mine spoil types with and without topsoil inoculation. Pages 1976-2000 in R. I. Barnhiesel (ed.). Proc., 23th Annual Meeting, American Society of Mining and Reclamation. Lexington, KY.

Skousen, J.G., C.D. Johnson, and K. Garbutt. 1994. Natural revegetation of 15 abandoned mine land sites in West Virginia. J. Environ. Qual. 23:1224-1230.

Skousen, J.G., J. Gorman, E. Pena-Yewtukhiw, J. King, J. Stewart, P. Emerson, and C. Delong. 2009. Hardwood tree survival in heavy ground cover on reclaimed land in West Virginia: mowing and ripping effects. Journal of Environmental Quality 38:1400-1409.

Smith, R. and M. Dallman. 1996. Forest gap use by breeding Black-throated Green Warblers. Wilson Bulletin 108:588-591.

Southern, W.E. 1958. Nesting of the Red-eyed Vireo in the Douglas Lake region, Michigan. 
Jack-Pine Warbler 36:105-130 and 185-207.

Summerville, K. S., T. O. Crist, J. K. Kahn, and J. C. Gering. 2003. Community structure of arboreal caterpillars within and among four tree species of the eastern deciduous forest. Ecological Entomology 28:747-757.

Summerville, K.S., and T.O. Crist. 2008. Structure and conservation of lepidopteran communities in managed forests of northeastern North America: a review. The Canadian Entomologist 140:475-494.

USDA Soil Conservation Service. 1975. Soil survey of Fayette and Raleigh counties, West Virginia. $76 \mathrm{p}$.

Wade, G. L. 1989. Grass competition and establishment of native species from forest soil seed banks. Landscape and Urban Planning 17:135-149.

Weakland, C. A. 2000. Effects of diameter-limit and two-aged timber harvesting on songbird populations on an industrial forest in central West Virginia. Dissertation, West Virginia University, Morgantown.

Wenny, D. G., Clawson, R. L., Faaborg, J., and S. L. Sheriff. 1993. Population density, habitat selection and minimum area requirements of three forest-interior warblers in central Missouri. Condor 95:968-979.

Whittaker, R. H., 1952. A study of summer foliage insect communities in the Great Smoky Mountains. Ecol. Monogr. 22: 1-44.

Whittaker, R. H. 1956. Vegetation of the Great Smoky Mountains. Ecological Monographs 26:180.

Wickham, J.D., Ritters, K.H., Wade, T.G., Coan, M., and C. Homer. 2007. The effect of Appalachian mountaintop mining on interior forest. Landscape Ecology 22:179-187.

Wood, P.B., Bosworth, S.B., Dettmers, R., 2006. Cerulean warbler abundance and occurrence relative to large-scale edge and habitat characteristics. Condor 108(1):154-165.

Wood, P.B., J.W. Edwards, and C.A. Weakland. 2001. Terrestrial vertebrate (breeding songbird, raptor, small mammal, herpetofaunal) of forested and reclaimed sites. Final report submitted to EIS steering committee. Morgantown, West Virginia. 149 pp.

Zuur, A. F., E. N. Ieno, N. J. Walker, A. A. Saveliev, and G. M. Smith. 2009. Mixed effects models and extensions in ecology with R. Springer, New York, New York, USA. 
Table 1. Variables used in environmental fitting with the avian assemblage ordination. Values are the means from mineland $(n=14)$ and reference $(n=14)$ transects, each of which is the average of four plots. Data was collected in 2011 from New River Gorge National River, West Virginia.

\begin{tabular}{|c|c|c|c|c|}
\hline & \multicolumn{2}{|c|}{ Mineland $(n=14)$} & \multicolumn{2}{|c|}{ Reference $(n=14)$} \\
\hline & Mean & $\mathrm{SE}$ & Mean & SE \\
\hline \multicolumn{5}{|l|}{ Groundcover } \\
\hline downed log cover $(\%)$ & 5.3 & 0.9 & 3.4 & 0.7 \\
\hline leaf litter cover (subplot \%) & 75.4 & 3.3 & 87.8 & 1.3 \\
\hline litter depth $(\mathrm{cm})$ & 1.7 & 0.1 & 2.5 & 0.1 \\
\hline litter cover (whole plot \%) & 50.2 & 3.0 & 76.9 & 2.2 \\
\hline bareground cover $(\%)$ & 11.4 & 1.3 & 5.3 & 0.9 \\
\hline forb cover $(\%)$ & 29.9 & 2.9 & 5.2 & 1.2 \\
\hline woody cover (\%) & 8.5 & 1.7 & 12.7 & 1.5 \\
\hline \multicolumn{5}{|l|}{ Subcanopy } \\
\hline saplings ha ${ }^{-1}$ & 80.4 & 16.2 & 121.9 & 7.8 \\
\hline sapling cover $(\%)$ & 15.4 & 2.8 & 21.6 & 1.5 \\
\hline shrub stems ha ${ }^{-1}$ & 404.9 & 145.8 & 343.3 & 57.2 \\
\hline shrub cover $(\%)$ & 6.3 & 1.3 & 5.1 & 0.8 \\
\hline \multicolumn{5}{|l|}{ Stocking } \\
\hline small trees ha ${ }^{-1}(8-23 \mathrm{~cm} \mathrm{dbh})$ & 233.5 & 25.7 & 330.8 & 22.1 \\
\hline med. trees $\mathrm{ha}^{-1}(23-38 \mathrm{~cm} \mathrm{dbh})$ & 145.5 & 8.6 & 138.8 & 10.4 \\
\hline large trees ha ${ }^{-1}(>38 \mathrm{~cm} \mathrm{dbh})$ & 100.4 & 8.4 & 75.9 & 6.0 \\
\hline total trees ha ${ }^{-1}(>8 \mathrm{~cm} \mathrm{dbh})$ & 479.5 & 25.3 & 545.5 & 18.6 \\
\hline basal area $\left(\mathrm{m}^{2} \mathrm{ha}^{-1}\right)$ & 34.1 & 1.5 & 29.1 & 0.7 \\
\hline snags ha ${ }^{-1}$ & 58.9 & 5.1 & 27.7 & 6.5 \\
\hline \multicolumn{5}{|l|}{ Foliage density (\%) } \\
\hline understory foliage $(0-6 \mathrm{~m})$ & 15.7 & 1.9 & 17.5 & 1.3 \\
\hline midstory foliage (6-18m) & 36.9 & 3.1 & 43.1 & 1.8 \\
\hline overstory foliage (>18m) & 39.5 & 3.5 & 34.9 & 2.0 \\
\hline vertical foliage diversity & 30.8 & 1.0 & 32.0 & 0.7 \\
\hline \multicolumn{5}{|l|}{ Topographic and misc. } \\
\hline slope (\%) & 12.8 & 0.9 & 10.2 & 0.6 \\
\hline solar radiation $\left(1,000 \mathrm{WH} / \mathrm{m}^{2}\right)$ & 1317.7 & 13.7 & 1326.6 & 10.2 \\
\hline tree diversity $\left(H^{\prime}\right)$ & 1.25 & 0.07 & 1.67 & 0.04 \\
\hline canopy vines $\mathrm{ha}^{-1}$ & 64.3 & 13.0 & 6.7 & 3.3 \\
\hline
\end{tabular}


Table 2. Correlations between vector (linear) and surface (general additive modeling) fitting between habitat and topographical variables and the 3-dimensional non-metric dimensional scaling solution for avian assemblages within mineland and reference forest. $P$-values from vector fitting are derived from 999 permutations of the data. Statistical significance was $p<0.05$.

\begin{tabular}{|c|c|c|}
\hline Variable & Vector $r^{2}(p$-value $)$ & Surface $r^{2}(p$-value $)$ \\
\hline \multicolumn{3}{|l|}{ Groundcover } \\
\hline bareground cover & $0.28(0.048)$ & $0.22(0.02)$ \\
\hline litter cover & $0.50(0.005)$ & $0.66(<0.001)$ \\
\hline litter depth & $0.46(0.003)$ & $0.63(<0.001)$ \\
\hline forb cover & $0.55(0.001)$ & $0.64(<0.001)$ \\
\hline woody groundcover & $0.12(0.39)$ & $0.10(0.38)$ \\
\hline downed log cover & $0.19(0.18)$ & $0.11(0.49)$ \\
\hline \multicolumn{3}{|l|}{ Subcanopy } \\
\hline saplings $\mathrm{ha}^{-1}$ & $0.09(0.53)$ & $0.01(0.32)$ \\
\hline shrubs ha ${ }^{-1}$ & $0.18(0.17)$ & $0.62(<0.001)$ \\
\hline \multicolumn{3}{|l|}{ Stocking } \\
\hline small trees $\mathrm{ha}^{-1}(8-22.9 \mathrm{~cm} \mathrm{dbh})$ & $0.08(0.57)$ & $0.11(0.43)$ \\
\hline med. trees ha ${ }^{-1}(23-37.9 \mathrm{~cm} \mathrm{dbh})$ & $0.14(0.31)$ & $0.13(0.30)$ \\
\hline large trees $\mathrm{ha}^{-1}(>38 \mathrm{~cm} \mathrm{dbh})$ & $0.18(0.20)$ & $0.31(0.11)$ \\
\hline basal area & $0.20(0.17)$ & $0.38(0.055)$ \\
\hline snags ha ${ }^{-1}$ & $0.39(0.006)$ & $0.34(0.002)$ \\
\hline \multicolumn{3}{|l|}{ Canopy cover } \\
\hline understory cover $(0-6 \mathrm{~m})$ & $0.07(0.64)$ & $0.00(0.43)$ \\
\hline midstory cover (>6-18 m) & $0.10(0.43)$ & $0.00(0.41)$ \\
\hline overstory (>18 m cover) & $0.03(0.85)$ & $0.00(0.43)$ \\
\hline vertical complexity & $0.14(0.33)$ & $0.25(0.19)$ \\
\hline \multicolumn{3}{|l|}{ Topographic and misc. } \\
\hline slope & $0.09(0.49)$ & $0.11(0.51)$ \\
\hline solar radiation $\left(\mathrm{WH} / \mathrm{m}^{2}\right)$ & $0.03(0.86)$ & $0.05(0.67)$ \\
\hline tree diversity $\left(H^{\prime}\right)$ & $0.39(0.007)$ & $0.33(0.003)$ \\
\hline vines $h^{-1}$ & $0.44(0.003)$ & $0.43(0.004)$ \\
\hline
\end{tabular}


Table 3. Mean $( \pm \mathrm{SE})$ detections $\mathrm{ha}^{-1}$ for all species and habitat, foraging, and nesting guilds. Richness is the mean $( \pm \mathrm{SE})$ number of species $\mathrm{ha}^{-1}$. $P$-values are from Poisson GLMs using an analysis of deviance test in which the difference in deviance approximately follows a Chi-square distribution with 1 degree of freedom. Statistical testing for Shannon diversity $\left(H^{\prime}\right)$ was through analysis of variance (* indicates the value of the $F$-statistic). All tests included site as a fixed effect. Statistical significance was $p<0.05$.

\begin{tabular}{|c|c|c|c|c|c|c|}
\hline & \multicolumn{2}{|c|}{ Mineland forest } & \multicolumn{2}{|c|}{ Reference forest } & \multirow[b]{2}{*}{$\chi_{1}^{2}$} & \multirow[b]{2}{*}{$p$} \\
\hline & $\overline{\text { mean }}$ & $\overline{\mathrm{SE}}$ & mean & $\overline{\mathrm{SE}}$ & & \\
\hline Diversity $\left(H^{\prime}\right)$ & 1.84 & 0.10 & 1.97 & 0.07 & $0.90 *$ & 0.35 \\
\hline Richness & 3.97 & 0.42 & 3.85 & 0.24 & 2.28 & 0.13 \\
\hline \multicolumn{7}{|l|}{ Relative abundance } \\
\hline All species & 6.82 & 0.69 & 7.45 & 0.56 & 0.45 & 0.50 \\
\hline \multicolumn{7}{|l|}{ Habitat guilds } \\
\hline closed canopy & 1.01 & 0.15 & 2.08 & 0.23 & 9.53 & 0.002 \\
\hline broken canopy & 0.37 & 0.15 & 0.31 & 0.06 & 0.45 & 0.50 \\
\hline forest generalists & 5.39 & 0.57 & 5.34 & 0.39 & 2.61 & 0.11 \\
\hline \multicolumn{7}{|l|}{ Foraging guilds } \\
\hline hawking & 0.17 & 0.08 & 0.54 & 0.09 & 4.94 & 0.03 \\
\hline bark foragers & 0.75 & 0.16 & 1.06 & 0.18 & 0.65 & 0.42 \\
\hline foliage gleaners & 4.50 & 0.30 & 4.25 & 0.36 & 2.46 & 0.12 \\
\hline ground gleaners & 0.84 & 0.14 & 1.6 & 0.15 & 5.50 & 0.02 \\
\hline \multicolumn{7}{|l|}{ Nesting guilds } \\
\hline canopy & 3.95 & 0.41 & 3.99 & 0.33 & 1.49 & 0.22 \\
\hline subcanopy & 0.40 & 0.13 & 0.60 & 0.17 & 1.00 & 0.32 \\
\hline ground & 1.27 & 0.18 & 1.91 & 0.15 & 1.71 & 0.19 \\
\hline cavity & 0.95 & 0.18 & 0.88 & 0.15 & 0.57 & 0.45 \\
\hline
\end{tabular}


Table 4. Temporal and habitat model selection results for nest survival of Red-eyed Vireos breeding within mineland and reference forest in New River Gorge National River, 2011. $\log _{\mathrm{e}}(L)$ is the value of the maximize log-likelihood function, $\mathrm{K}$ is the number of parameters estimated by the model, $\triangle \mathrm{AIC}_{\mathrm{c}}$ is the scaled value of Akaike s Information Criterion for small sample sizes, and $w_{i}$ reflects the relative support attributed to a given model.

\begin{tabular}{|c|c|c|c|c|}
\hline & $\log _{e}(L)$ & $\mathbf{k}$ & $\Delta \mathbf{A I C}_{\mathbf{c}}$ & $w_{i}$ \\
\hline \multicolumn{5}{|l|}{ Temporal Models } \\
\hline Nest stage & -113.34 & 2 & 0 & 0.38 \\
\hline Nest stage + date & -113.22 & 3 & 1.77 & 0.16 \\
\hline Nest stage + date $^{2}$ & -112.26 & 4 & 1.88 & 0.15 \\
\hline Constant survival $^{\mathrm{c}}$ & -115.34 & 1 & 1.99 & 0.14 \\
\hline Date $^{2 b}$ & -113.79 & 3 & 2.92 & 0.09 \\
\hline Date & -114.88 & 2 & 3.08 & 0.08 \\
\hline \multicolumn{5}{|l|}{$\underline{\text { Habitat Models }}$} \\
\hline Nest stage & -113.34 & 2 & 0 & 0.34 \\
\hline Nest stage + forest type & -112.98 & 3 & 1.30 & 0.18 \\
\hline Nest stage + overstory cover & -113.04 & 3 & 1.42 & 0.17 \\
\hline Nest stage + vertical foliage density & -113.32 & 3 & 1.97 & 0.13 \\
\hline Nest stage + forest type + overstory cover & -112.78 & 4 & 2.93 & 0.08 \\
\hline Nest stage + forest type + vertical foliage density & -112.95 & 4 & 3.26 & 0.07 \\
\hline Global $^{\mathrm{a}}$ & -112.52 & 5 & 4.44 & 0.04 \\
\hline
\end{tabular}

\footnotetext{
${ }^{a}$ Includes all variables used in habitat models.

${ }^{b}$ Date $^{2}$ is the quadratic effect of date (date + date $\left.^{2}\right)$.

${ }^{\mathrm{c}}$ The null model.
} 
Table 5. Model-averaged parameter estimates, their unconditional standard errors (SE), and odds ratios (OR) with unconditional 95\% confidence intervals (CI) for habitat and temporal variables used in modeling nest survival of Red-eyed Vireos breeding within mineland and reference forest in New River Gorge National River, 2011. Odds ratios for vertical foliage density and overstory cover are for a $1 \%$ increase in the variable.

\begin{tabular}{lcccc}
\hline \multicolumn{1}{c}{ Parameter } & Estimate & SE & OR & $95 \%$ CI \\
\hline Vertical foliage density & -0.0011 & 0.0061 & 1.000 & $0.987,1.011$ \\
Overstory cover & 0.0023 & 0.0053 & 1.002 & $0.992,1.013$ \\
Mineland versus reference forest & 0.0672 & 0.1478 & 1.070 & $0.796,1.437$ \\
Nestling versus laying/incubation & -0.7225 & 0.3631 & 0.486 & $0.235,1.004$ \\
\hline
\end{tabular}

Table 6. Distribution of tree species used by Red-eyed Vireos for nest sites and the distribution of canopy gap types from those identified as being closest to vireo nests.

\begin{tabular}{lclc}
\hline \multicolumn{2}{c}{ Mineland nests $(\mathrm{n}=21)$} & \multicolumn{2}{c}{ Reference nests $(\mathrm{n}=24)$} \\
\hline Nest tree species & $\%$ & Nest tree species & $\%$ \\
\hline Red maple & 38.1 & Red maple & 29.2 \\
Yellow poplar & 28.6 & Scarlet oak & 20.8 \\
Slippery elm & 14.3 & Black oak & 16.7 \\
Black birch & 14.3 & Chestnut oak & 12.5 \\
White oak & 4.8 & White oak & 8.3 \\
& & Mockernut hickory & 4.2 \\
& & American beech & 4.2 \\
& & Black gum & 4.2 \\
\hline Nearest gap type & $\%$ & Nearest gap type & $\%$ \\
\hline Edaphic gap & 57.1 & Edaphic gap & 0.0 \\
Snag-created gap & 9.5 & Snag-created gap & 25.0 \\
Treefall gap & 33.3 & Treefall gap & 75.0 \\
\hline
\end{tabular}


Table 7. Means $( \pm \mathrm{SE})$ from nest measurements and habitat sampling for Red-eyed Vireo nest patches within mineland and reference forest in New River Gorge National River, West Virginia (2011). Variables used in classification tree modeling are listed under the "structural" heading (shrub and sapling cover were used instead of shrub and sapling density).

\begin{tabular}{|c|c|c|c|c|}
\hline & \multicolumn{2}{|c|}{ Mined $(n=21)$} & \multicolumn{2}{|c|}{ Reference $(n=24)$} \\
\hline & Mean & SE & Mean & SE \\
\hline \multicolumn{5}{|l|}{ Groundcover } \\
\hline bareground cover $(\%)$ & 11.0 & 3.1 & 1.9 & 0.7 \\
\hline forb cover $(\%)$ & 33.1 & 3.7 & 2.5 & 1.5 \\
\hline litter cover $(\%)$ & 49.5 & 4.2 & 70.8 & 2.3 \\
\hline woody cover $(\%)$ & 6.4 & 2.0 & 24.8 & 2.3 \\
\hline \multicolumn{5}{|l|}{ Subcanopy } \\
\hline shrub stems ha ${ }^{-1}$ & 384.5 & 124.8 & 666.7 & 89.5 \\
\hline shrub cover $(\%)$ & 4.6 & 0.9 & 7.1 & 0.7 \\
\hline saplings ha ${ }^{-1}$ & 41.7 & 9.0 & 139.6 & 23.2 \\
\hline sapling cover $(\%)$ & 11.7 & 2.5 & 21.1 & 4.2 \\
\hline \multicolumn{5}{|l|}{ Stocking } \\
\hline small trees $\mathrm{ha}^{-1}(8-22.9 \mathrm{~cm} \mathrm{dbh})$ & 211.9 & 33.5 & 370.8 & 21.8 \\
\hline med. trees ha ${ }^{-1}(23-37.9 \mathrm{~cm} \mathrm{dbh})$ & 136.9 & 15.8 & 139.6 & 13.9 \\
\hline large trees ha ${ }^{-1}(>38 \mathrm{~cm} \mathrm{dbh})$ & 76.2 & 11.4 & 93.8 & 7.7 \\
\hline total trees/ha $(>8 \mathrm{~cm} \mathrm{dbh})$ & 425.0 & 36.6 & 604.2 & 21.1 \\
\hline basal area $\left(\mathrm{m}^{2} \mathrm{ha}^{-1}\right)$ & 27.9 & 1.9 & 32.8 & 1.5 \\
\hline snags ha ${ }^{-1}$ & 63.1 & 12.3 & 25.0 & 5.2 \\
\hline \multicolumn{5}{|l|}{ Canopy cover (\%) } \\
\hline subcanopy foliage $(0-6 \mathrm{~m})$ & 14.4 & 2.0 & 22.7 & 2.0 \\
\hline midstory foliage $(>6-18 \mathrm{~m})$ & 38.8 & 2.7 & 39.8 & 2.4 \\
\hline overstory foliage (>18 m) & 44.9 & 3.7 & 40.5 & 1.5 \\
\hline vertical foliage density & 32.7 & 1.4 & 34.3 & 0.9 \\
\hline \multicolumn{5}{|l|}{ Nest measurements and misc. } \\
\hline nest height $(\mathrm{m})$ & 20.7 & 1.3 & 18.9 & 1.4 \\
\hline nest tree height $(\mathrm{m})$ & 26.7 & 1.3 & 24.3 & 1.8 \\
\hline nest tree canopy depth (m) & 12.2 & 1.3 & 10.3 & 1.0 \\
\hline nest tree $\mathrm{dbh}(\mathrm{cm})$ & 37.8 & 3.2 & 34.9 & 3.4 \\
\hline nest to canopy top (m) & 6.0 & 0.9 & 5.4 & 0.8 \\
\hline nest to canopy bottom (m) & 6.2 & 1.0 & 4.8 & 0.7 \\
\hline canopy vines $\mathrm{ha}^{-1}$ & 92.9 & 23.0 & 3.1 & 2.3 \\
\hline gap distance (m) & 16.2 & 2.7 & 26.0 & 4.1 \\
\hline nearest dominant height $(\mathrm{m})$ & 29.9 & 1.1 & 28.4 & 0.7 \\
\hline
\end{tabular}




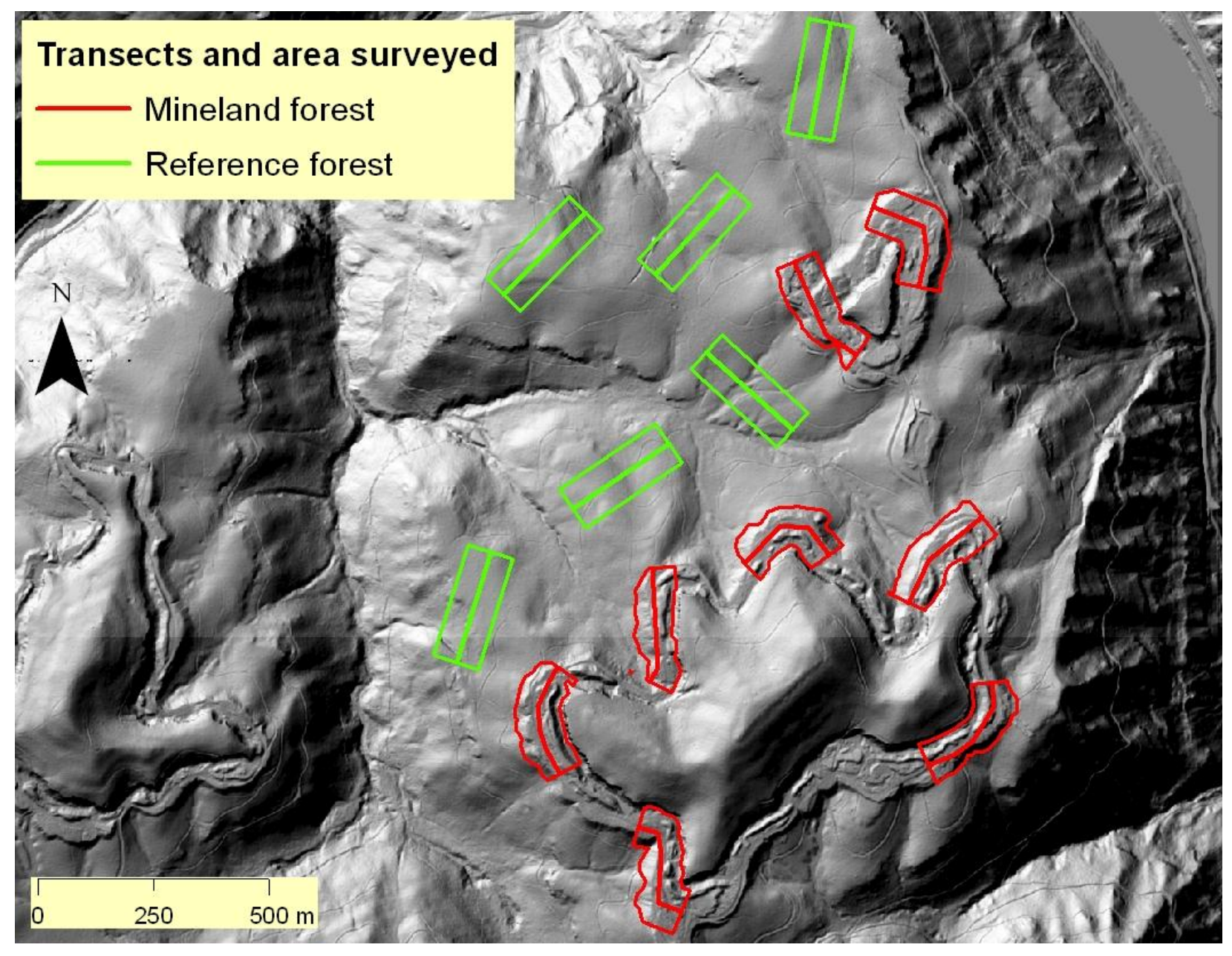

Fig. 1. Location of line transects surveyed in 2011 at the Sewell Knob site in New River Gorge National River, West Virginia. The area surveyed corresponds to $50 \mathrm{~m}$ strips on each side of the $250 \mathrm{~m}$ transect line or to the full extent of the habitat when mineland width is $<100 \mathrm{~m}$. 


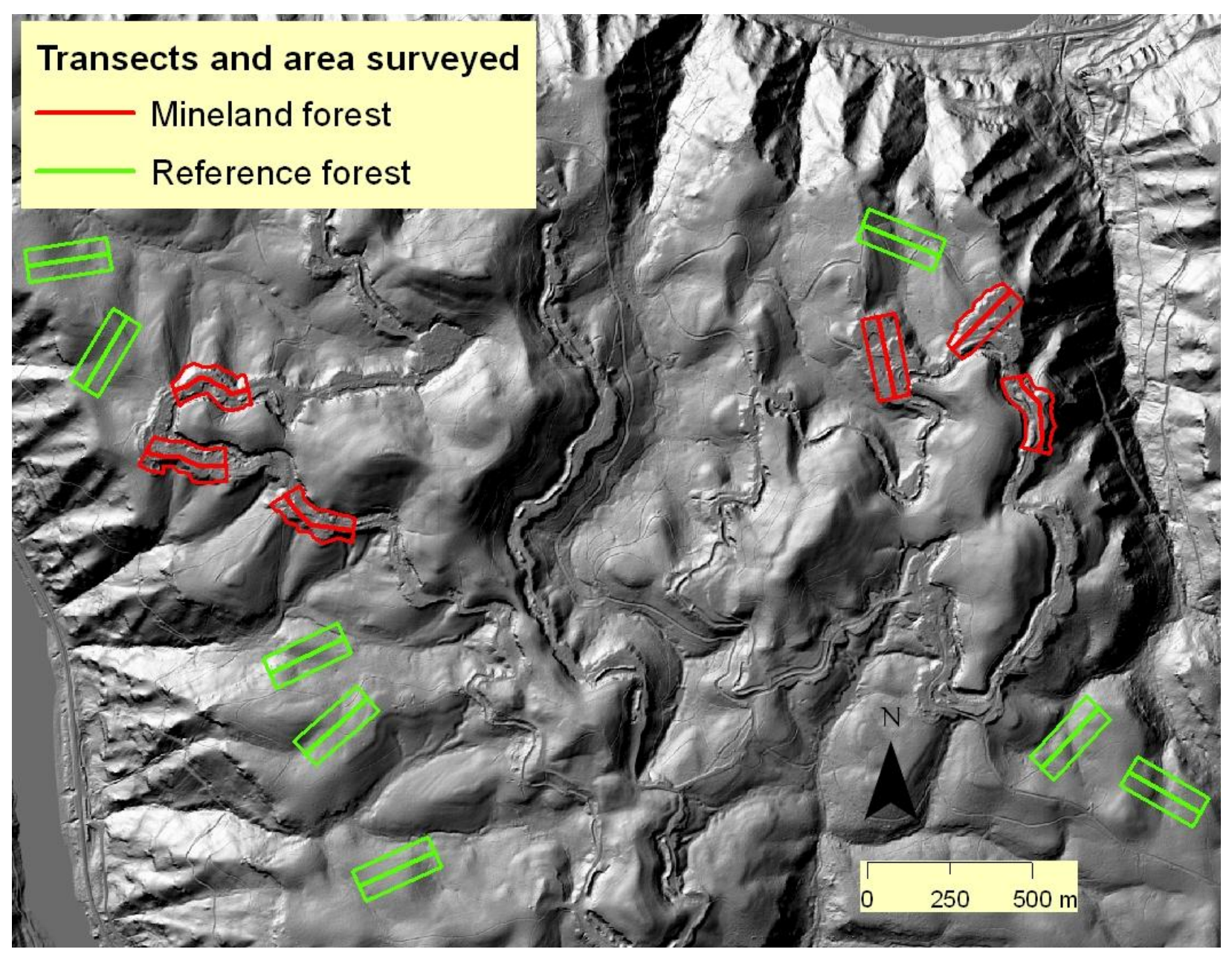

Fig. 2. Location of line transects surveyed in 2011 at the Mollyes Creek site (west) and Fire Creek site (east) in New River Gorge National River, West Virginia. The area surveyed corresponds to $50 \mathrm{~m}$ strips on each side of the $250 \mathrm{~m}$ transect or to the full extent of the habitat when mineland width is $<100 \mathrm{~m}$. 


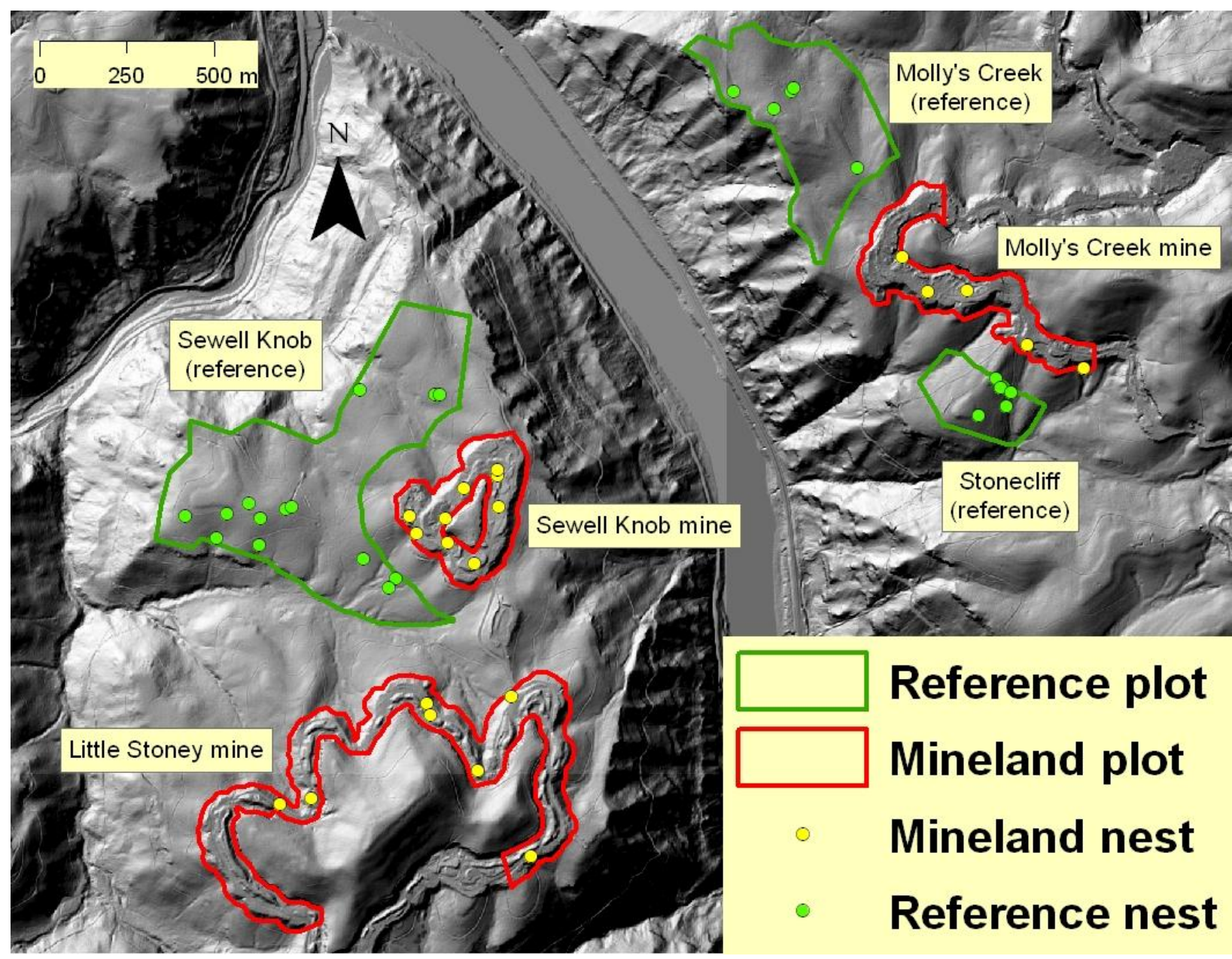

Fig. 3. Location of Red-eyed Vireo nest plots and nests that were monitored within those plots in 2011 in New River Gorge National River, West Virginia. Area and nests monitored for each plot were: Sewell Knob reference (36.4 ha, n=14), Sewell Knob mine ( 8.8 ha, n=9), Little Stoney mine (20.8 ha, n=7), Molly"s Creek reference (17.4 ha, $n=5)$, Molly" ${ }^{\text {ee }}$ Creek mine (10.1 ha, $\mathrm{n}=5$ ), and Stonecliff reference (5.4 ha, $\mathrm{n}=5$ ). 

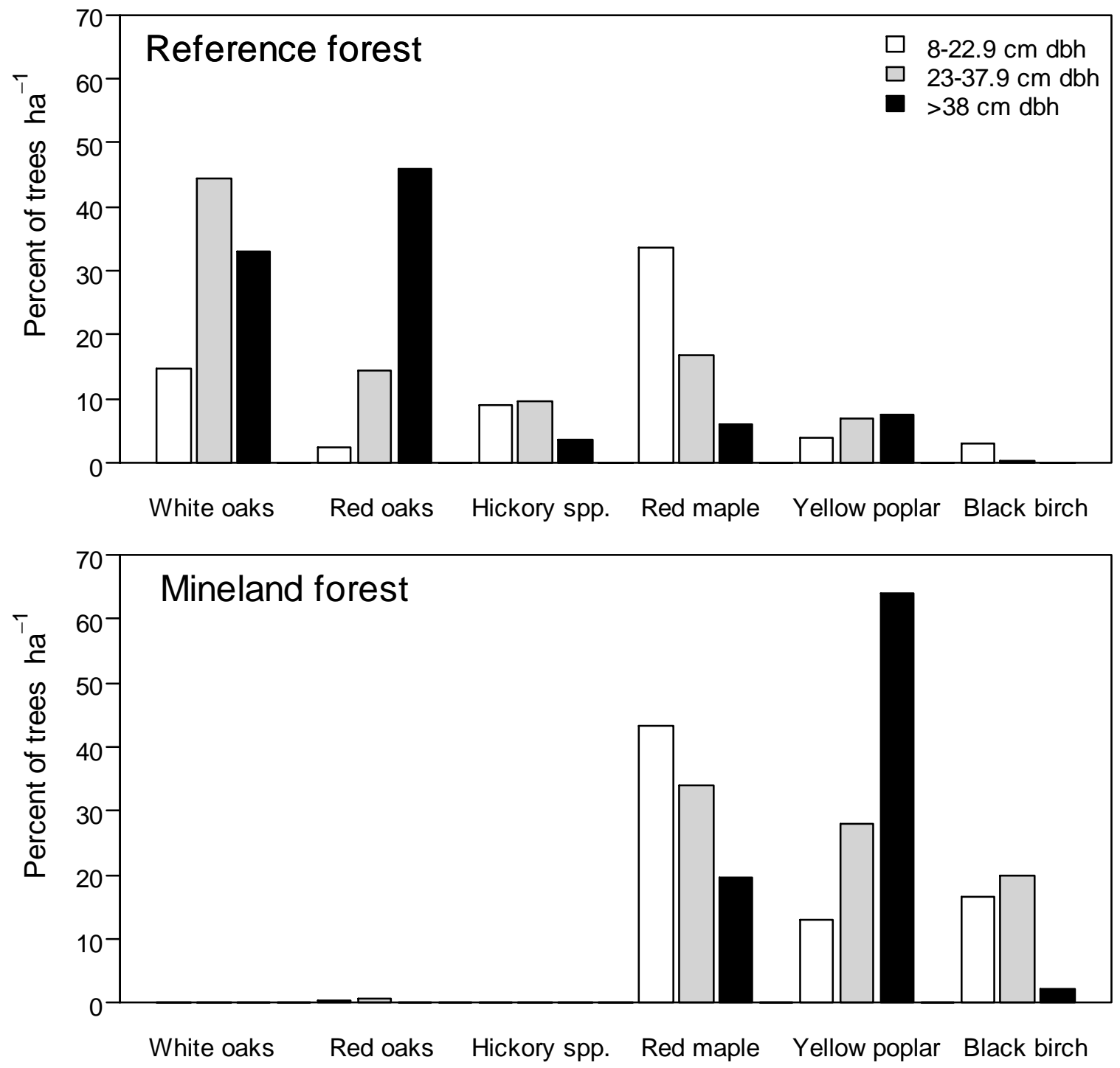

Fig. 4. Distribution of tree species groups by size class from reference $(n=56)$ and mineland forest plots $(\mathrm{n}=56)$ sampled along bird survey transects in New River Gorge National River, West Virginia (2011). This is expressed as the proportion of tree density within a size class. White oaks include chestnut and white oak. Red oaks include black, scarlet, and northern red oak. 


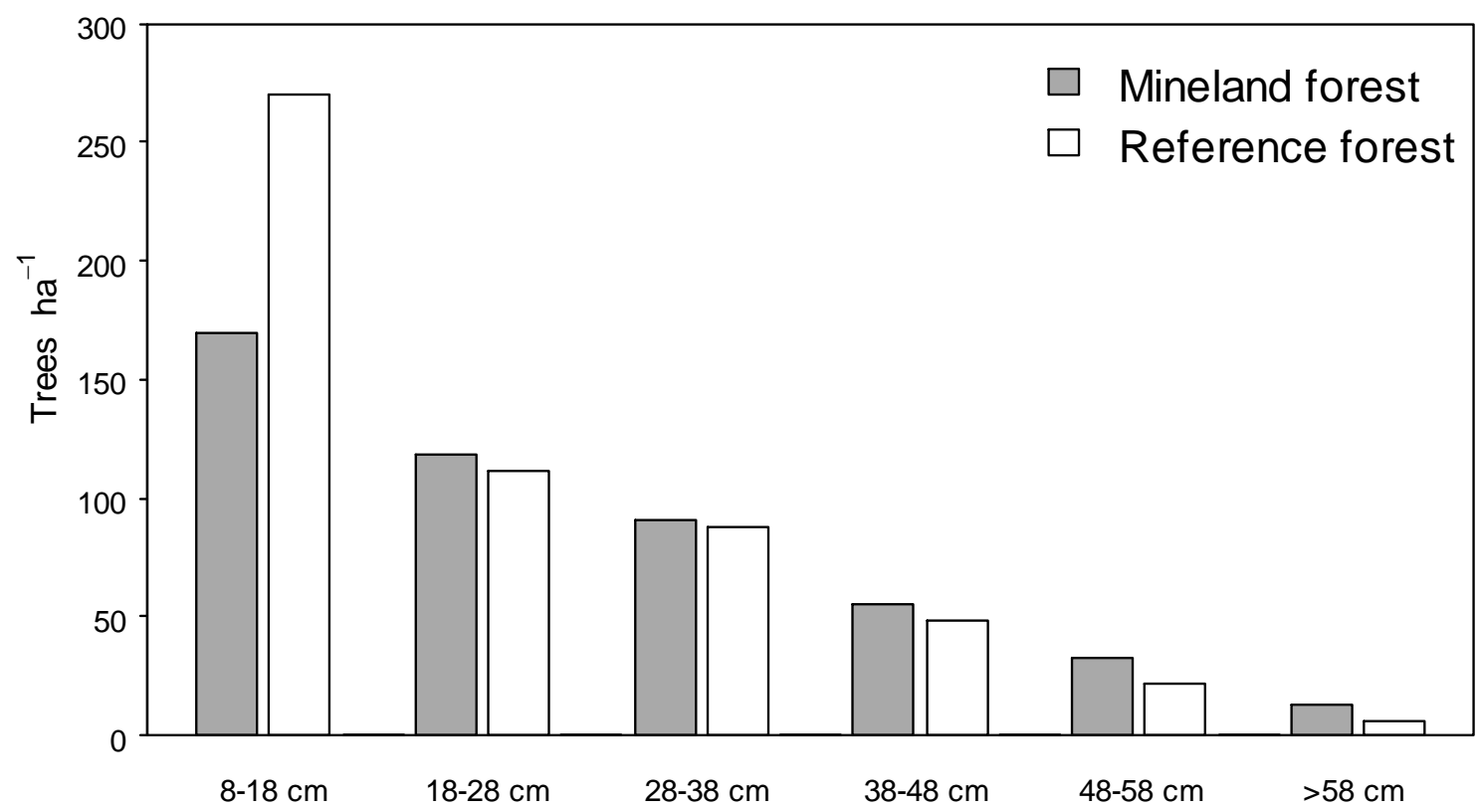

Fig. 5. Diameter distribution from reference $(n=56)$ and mineland forest plots $(n=56)$ sampled along bird survey transects in New River Gorge National River, West Virginia (2011).

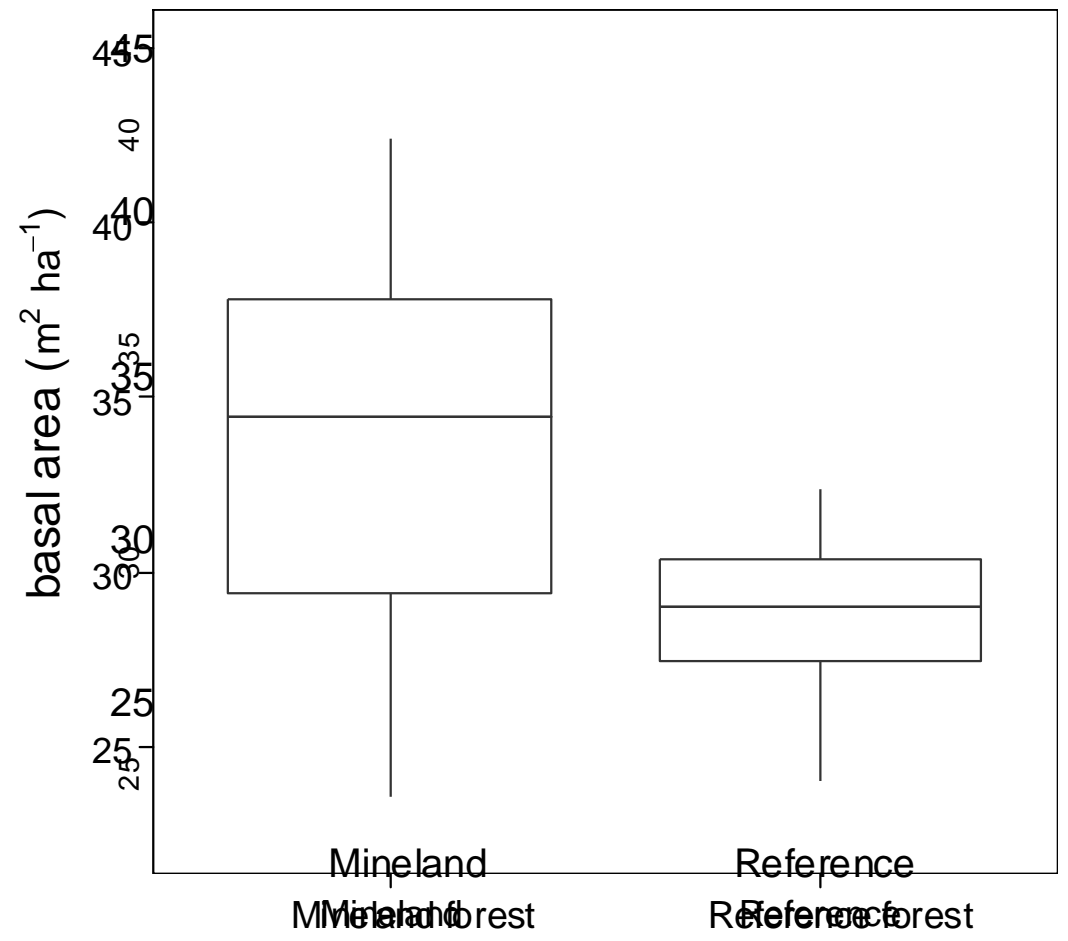

Figure 6. Boxplot of basal area $\left(\mathrm{m}^{2} \mathrm{ha}^{-1}\right)$ for transects within mineland and reference forest. 


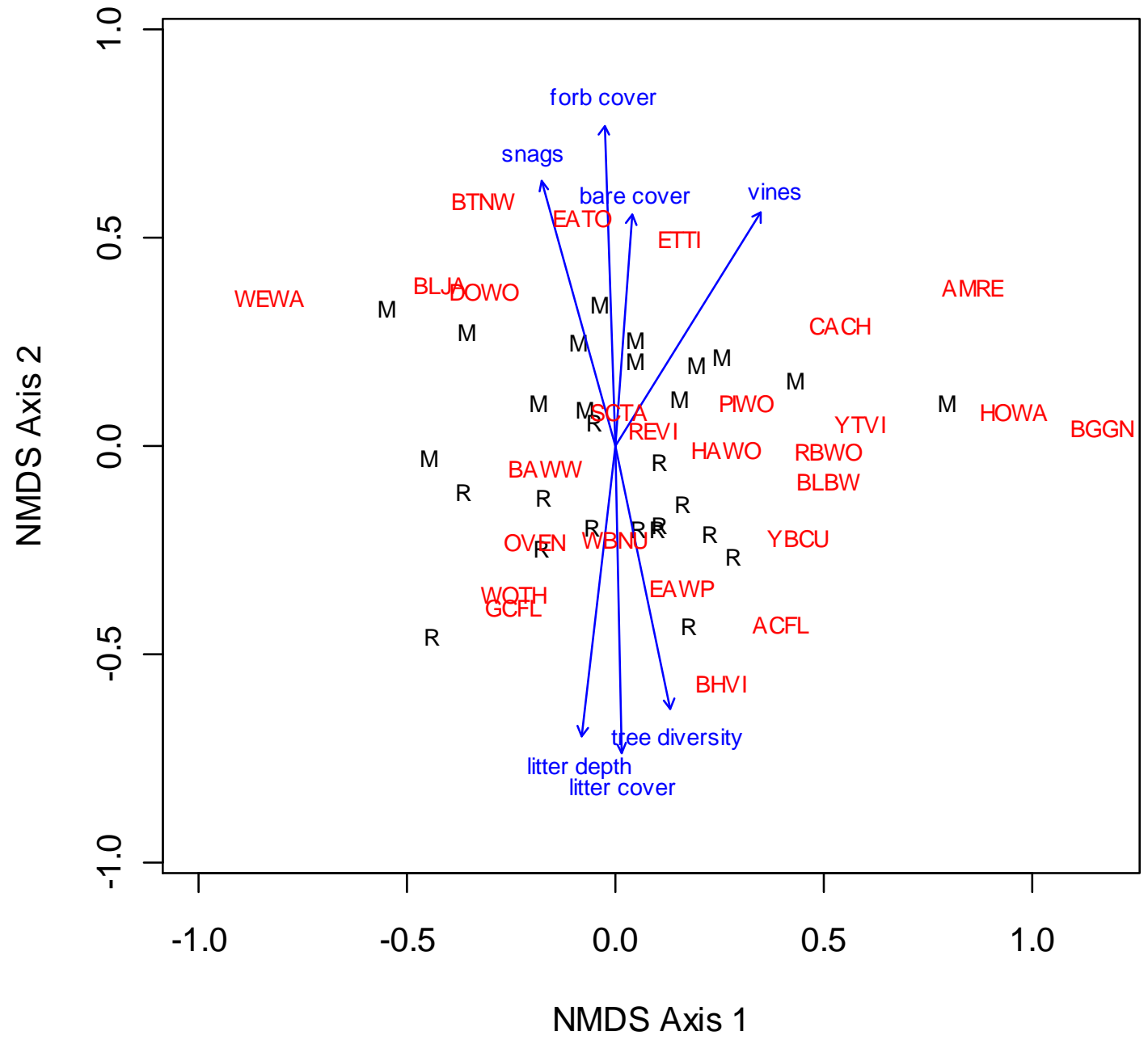

Figure 7. Dimensions 1 and 2 from a 3-dimensional non-metric dimensional scaling ordination for avian assemblages within mineland $(M)$ and reference $(R)$ forest. Stress was 15.3 for the 3dimensional solution ( 2 convergent solutions after 6 runs). The vectors plotted are for those variables that had linear $p<0.05$ (axes 1-3). The length of the arrow corresponds to the correlative strength of the gradient-ordination relationship. Weighted mean positions for all bird species are shown. Species codes are listed in Appendix C. 

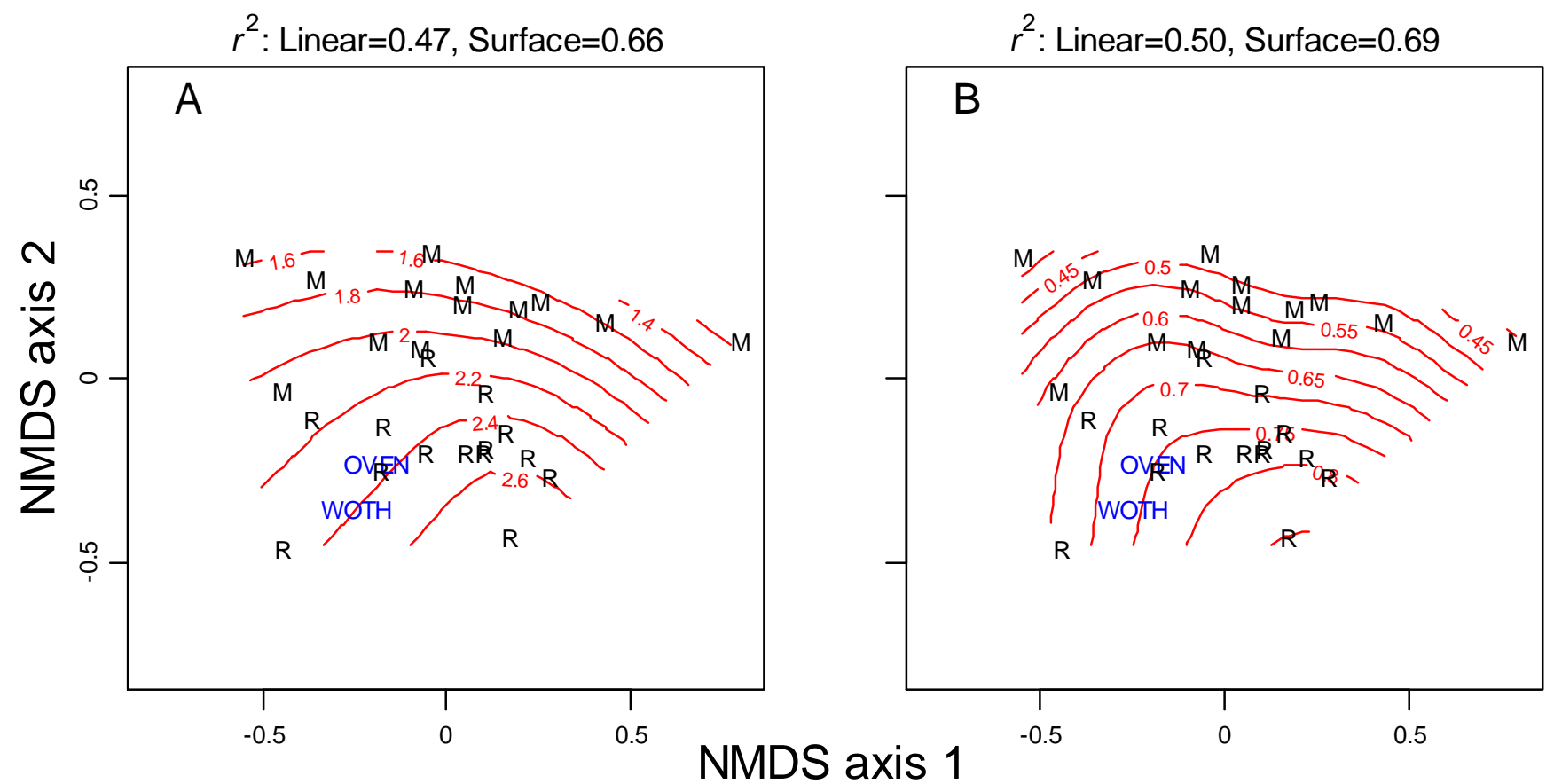

Fig. 8. Non-metric dimensional scaling ordinations fit with surface contours using GAM for A) leaf litter depth, (contours are in $\mathrm{cm}$ ) and B) litter cover. Mean weighted locations for species in the ground gleaning guild (Ovenbird and Wood Thrush). Linear and surface fit $r^{2}$ values for the ordination-gradient relationship are shown above their corresponding frames. Surface fits are significant $(p<0.001)$. Assemblage type is overlaid; mineland $(\mathrm{M})$ and reference $(\mathrm{R})$ forest.

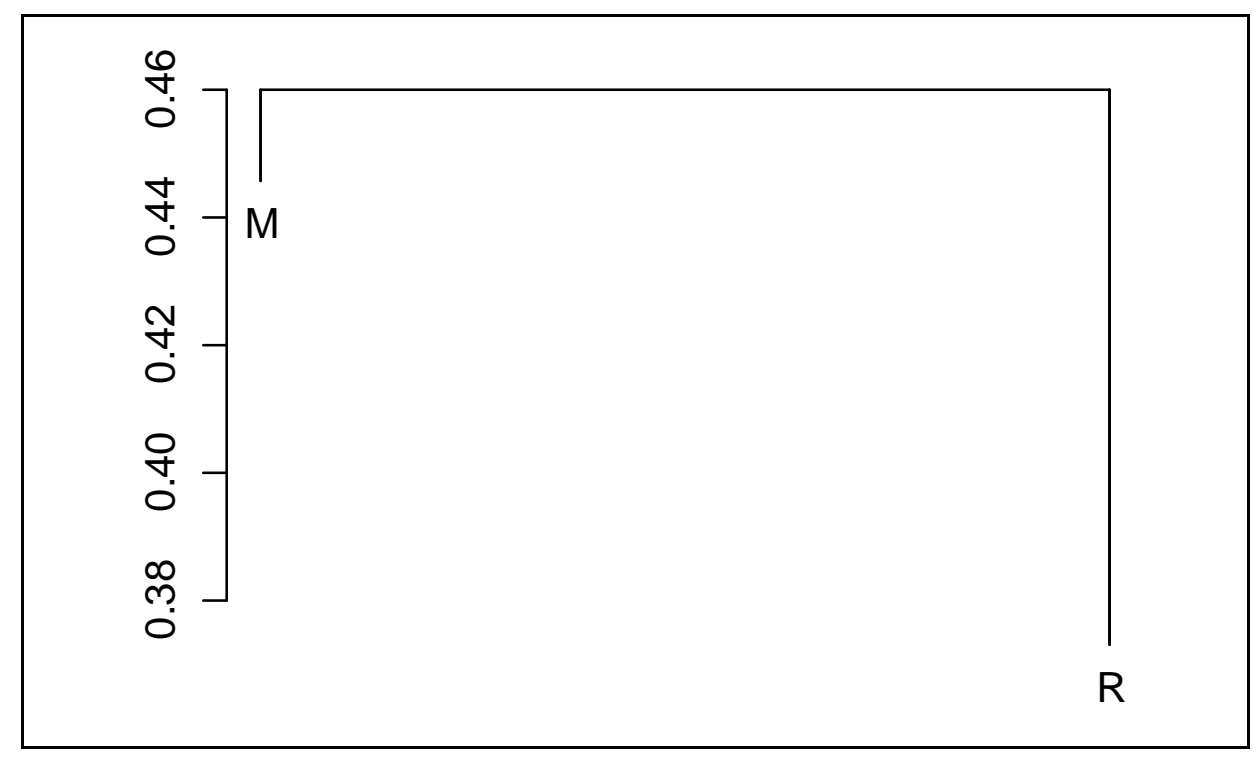

Figure 9. Mean dissimilarity dendrogram for mineland $(\mathrm{M})$ and reference $(\mathrm{R})$ forest assemblages. Mean between-group dissimilarity $(\mathrm{Bbar})=0.460$. Mean within-group dissimilarity $($ Wbar $)=$ 0.410 . 

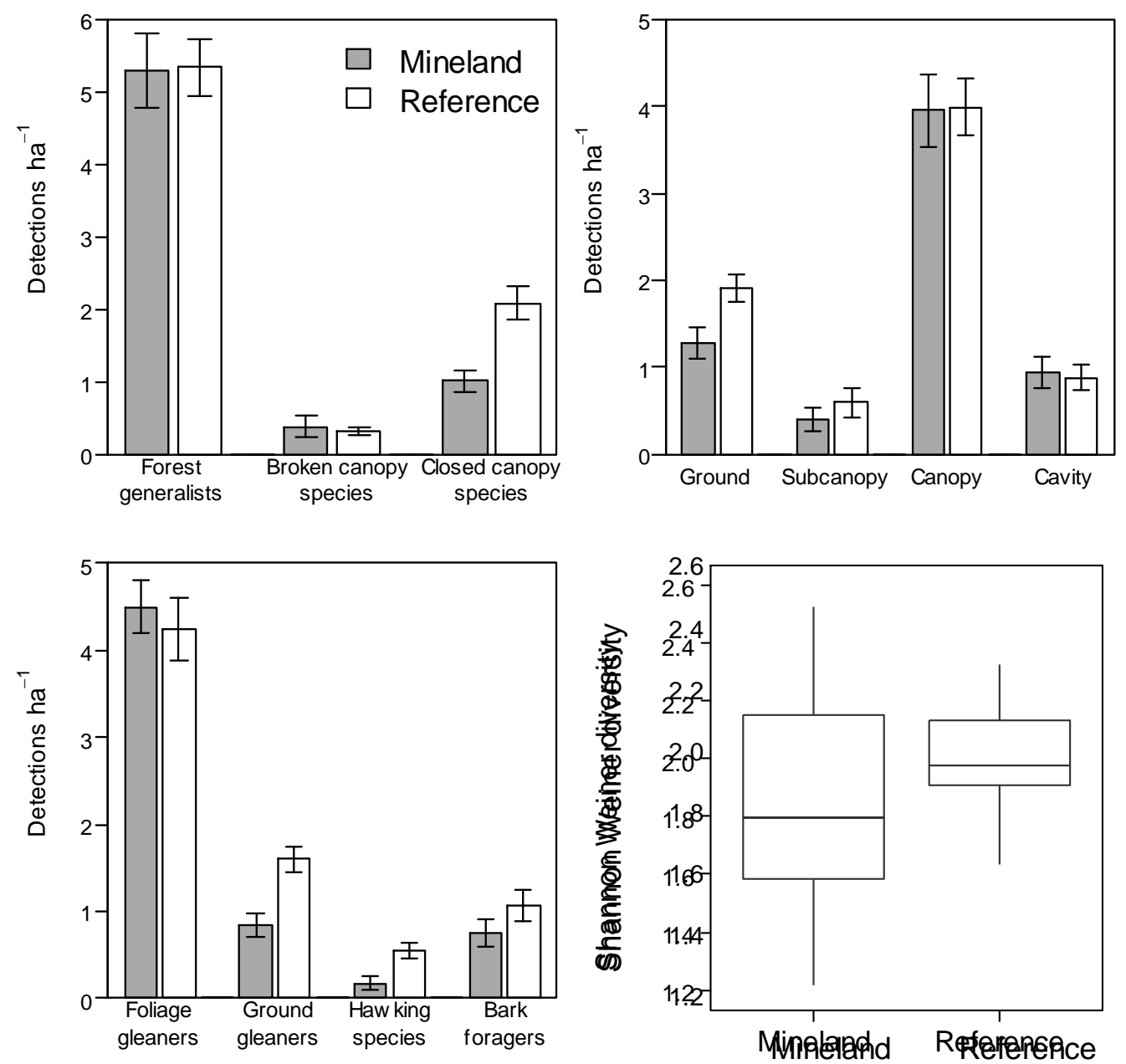

Figure 10. Mean detections $\mathrm{ha}^{-1}( \pm \mathrm{SE})$ for habitat, nesting, and foraging guilds within mineland (gray) and reference forest (white). The boxplot for Shannon diversity $\left(H^{\prime}\right)$ is also shown. 

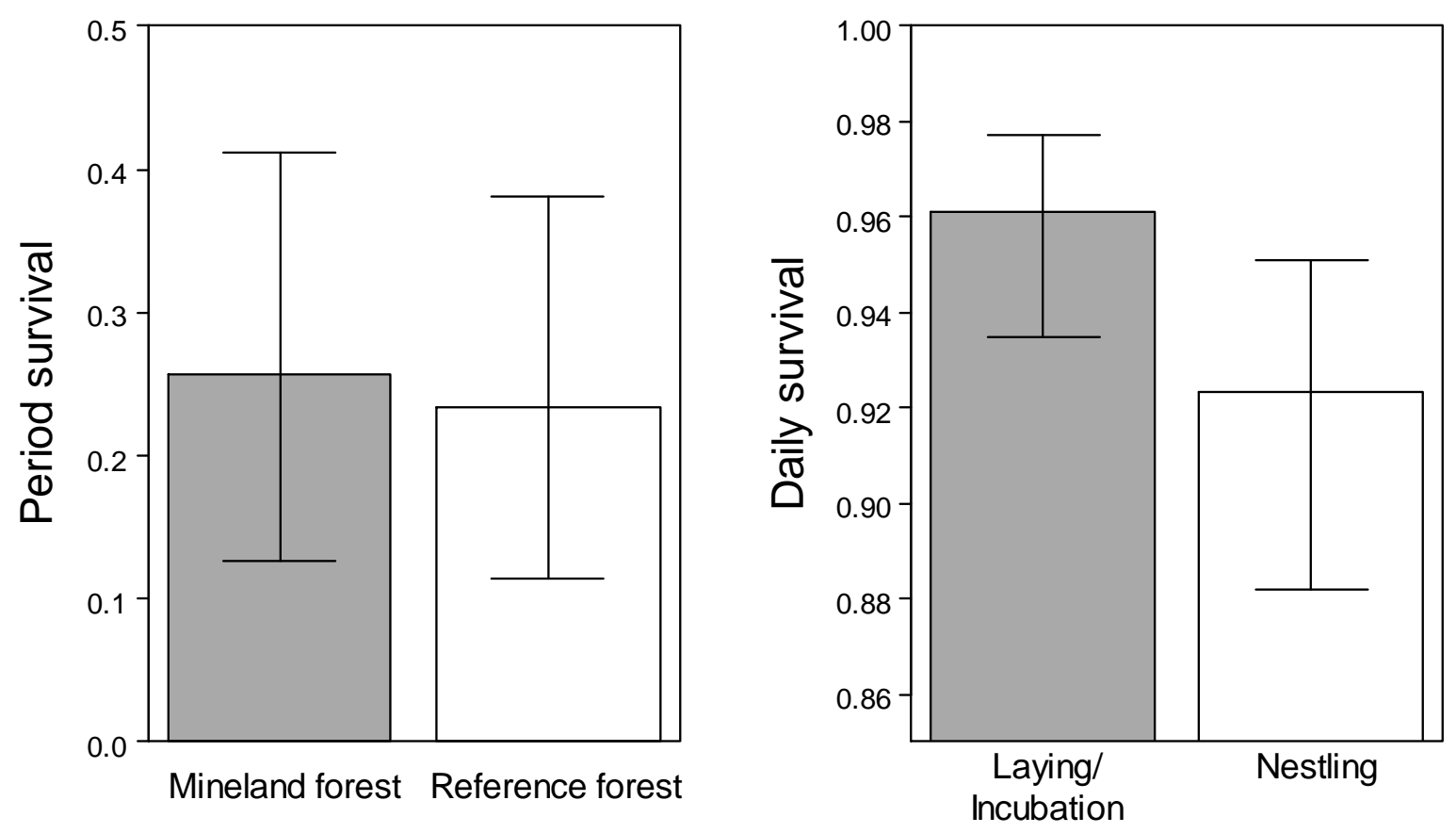

Figure 11. Model-averaged estimates and 95\% CIs for period survival of Red-eyed Vireo nests within mineland and reference forest and for daily survival for laying/incubation and nestling stages. 


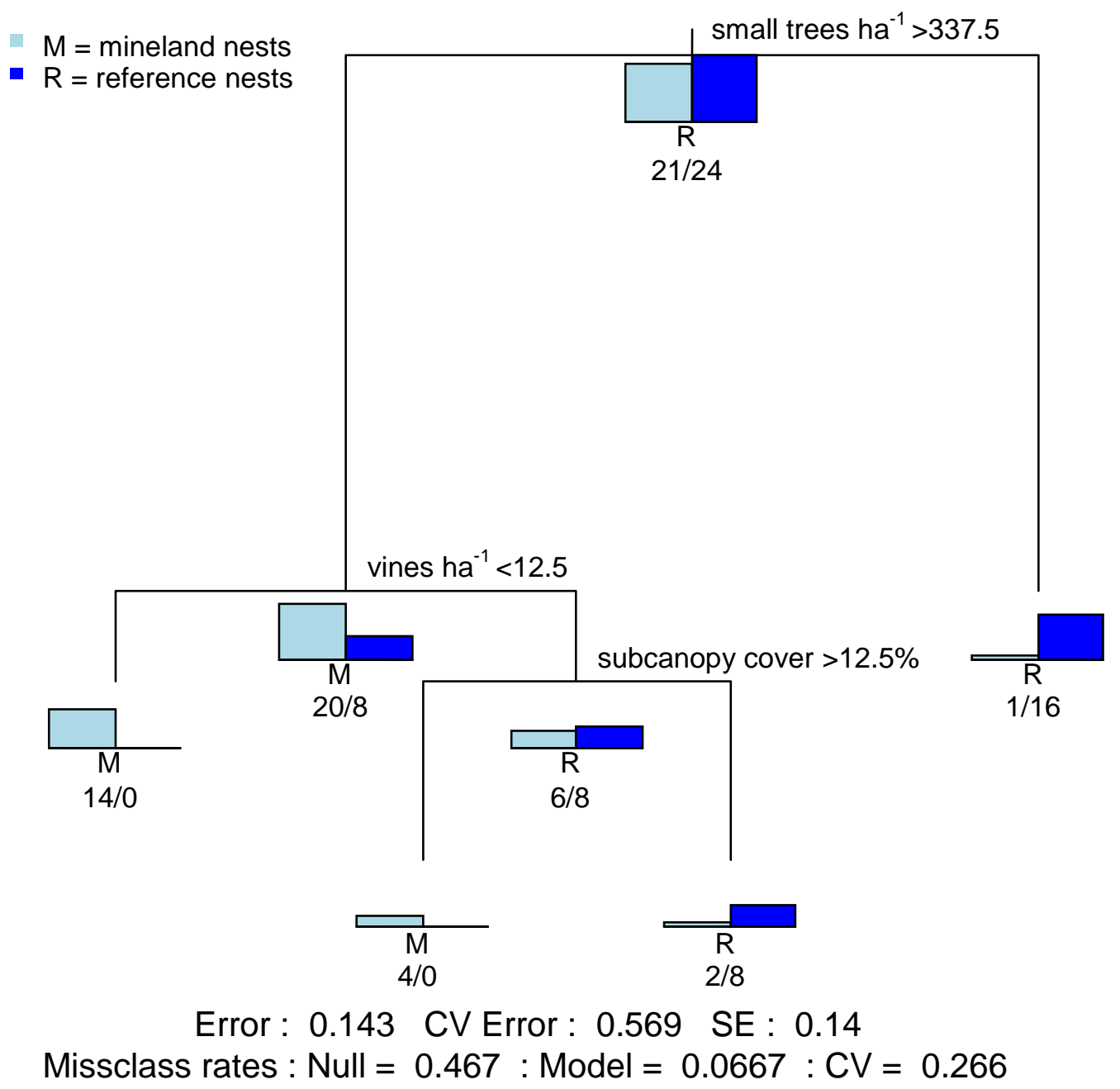

Fig. 12. Classification tree for structural characteristics within Red-eyed Vireo nest patches within mineland $(M ; n=21)$ and reference $(R ; n=24)$ forest in New River Gorge NR, West Virginia (2011). Nodes are classified according to the dominant forest type. 


\section{Chapter 3}

THE EFFECT OF FORESTED, ABANDONED MINE LANDS ON AVIAN ASSEMBLAGE STRUCTURE 


\section{ABSTRACT}

Despite the extent to which they bisect Appalachian forest landscapes, the influence of forested pre-SMCRA minelands on the avian assemblage has received little study. In 2010, I initiated research with an objective of examining patterns in avian assemblage structure in mined and unmined forest and also across two broad classes of minelands, compacted bench minelands and loose-dumped bench minelands. In New River Gorge National River and Plum Orchard Wildlife Management Area, I conducted avian point counts and sampled forest structure and composition within four habitat types: loose-dumped bench minelands, compacted bench minelands, unmined plateau, and unmined steep slope. Non-metric dimensional scaling (NMDS) ordination indicated that minelands with loose-dumped benches had minimal effect on assemblage structure. Only compacted bench minelands had a relatively distinct avian assemblage due in part to restricted forest development along benches and edge influence along highwalls. Dense midcanopy cover, relatively low levels of overstory cover, and substantially higher canopy vine density characterized compacted bench minelands. Species which use the subcanopy and midcanopy for nesting and foraging, American Redstart, Rose-breasted Grosbeak, and Worm-eating Warbler, differentiated the avian assemblage associated with compacted bench minelands. Relative abundance of the closed-canopy guild was lower within mined forest than within unmined forest. For some mature forest restricted species, i.e. Blueheaded Vireo and Ovenbird, mineland habitats may have low suitability due to relatively low subcanopy cover within loose-dumped bench sites and relatively low overstory cover and canopy height along compacted benches.

\section{INTRODUCTION}

In much of Appalachia, mineland forest is now a component of a landscape that was extensively contour stripped prior to the passage of the Surface Mining Control and Reclamation Act (SMCRA) in 1977. Prior to SMCRA, mines used a "shoot and shove" method for extraction resulting in an exposed highwall, bench-land along its face, and an outslope comprised of loose spoil that had been pushed below. Mines were left in this "shoot and shove" configuration and reclamation practices varied from state to state (Brown 1962). Mature forest has since developed on many of these sites. However, forest development varies according to the extent of loosedumped spoil atop benches, and on many of these sites mature forest is not contiguous. 
Despite the extent to which they bisect Appalachian forest landscapes, the influence of forested pre-SMCRA minelands on the avian assemblage has received little study. Pre-SMCRA minelands may represent significant structural and compositional contrast to adjacent forest on unmined soils. As such, the presence of forested pre-SMCRA minelands on the landscape may result in an avian assemblage distinct from the one found within forest lacking pre-SMCRA minelands (hereafter, unmined forest). In addition, forest development and, consequently, the degree of edge influence along highwalls may differ between minelands with compacted benches and those with loose-dumped spoil distributed atop benches. Therefore, avian assemblage composition could also vary in response to differences in habitat structure between compacted bench minelands and loose-dumped bench minelands. The objective of this study was to examine patterns in avian assemblage structure in mined and unmined forest and also across two broad classes of minelands, compacted bench minelands and loose-dumped bench minelands.

\section{SITE DESCRIPTIONS AND METHODS}

Study area and sampling design. The study area is located atop the New River Plateau and along the steep, upper slopes within New River Gorge National River and Plum Orchard Wildlife Management Area (WMA) in southern West Virginia (Appendix F). The oak-hickory and mixed-mesophytic forest within these public landholdings is largely unfragmented and varies compositionally along a soil moisture and fertility gradient (Vanderhorst et al. 2007). Oak-hickory forest occupies much of the relatively xeric plateau with white (Quercus alba), chestnut (Quercus prinus), scarlet (Quercus coccinea), and black oak (Quercus velutina) comprising the predominant canopy species. Along the steep, upper slopes within Plum Orchard WMA and the New River Gorge, the forest is of the mixed-mesophytic type and northern red oak (Quercus rubra), chestnut oak, hickory spp. (Carya spp.), red maple (Acer rubrum), sugar maple (Acer saccharum), yellow poplar (Liriodendron tulipifera), basswood (Tilia americana), and American beech (Fagus grandifolia) are dominants. Elevations within the study area are $550-730 \mathrm{~m}$.

I selected pre-SMCRA abandoned minelands based on the following criteria: the presence of mature hardwood forest that had established naturally, the absence of roads along benches, and the presence of adjacent, unmined mature hardwood forest. I established one set of paired point count transects (mined and unmined) at each of five sites. Because variation in slope 
steepness contributed strongly to differences in tree species composition and mineland habitat structure, mined and unmined transects were classified on the basis of slope steepness. During early contour mining, slope steepness was a primary factor in determining the extent to which successive cuts could be made along a contour and, consequently, in how loose-dumped spoil was distributed. In areas of greater slope steepness, mine operators encountered a rapidly increasing overburden to coal ratio with each progressive cut into the mountainside.

Consequently, along steeper slopes, benches tend to be narrow and relatively compacted with all loose-dumped spoil pushed into outslopes.

Three study sites were located within oak-hickory forest atop the New River Plateau (Molly's Creek, Fire Creek, and Sewell Knob) (Fig. 1). Within these sites, minelands were relatively wide with spoil ridges distributed atop benches (Figures 2-3) and thus, were classified as loose-dumped benches. Mature forest cover was generally contiguous within these minelands. Unmined transects within these sites were classified as unmined plateau forest. Two study sites were located within mixed-mesophytic forest along the steep, upper slopes of the New River Gorge (Turkey Spur) and Plum Orchard WMA (Fig. 1). Mined transects within these sites were classified as compacted benches because they were narrow and had level benches upon which mature forest had often not developed (Figures 4-5). Unmined transects within these sites were classified as unmined, steep slope forest.

Within minelands, forest structure along highwalls also varied according to slope steepness. Within loose-dumped bench sites, the mineland canopy largely obscured the edge once created by the highwall. Within compacted bench sites, the mineland canopy rarely exceeded the height of the highwall and highwalls were occasionally collapsed with vinechoked, young forest vegetation extending from the top of the highwall to the bench below.

Using aerial photos taken in 1945 and 1957, I established that all five mine sites were mined between 1945 and 1957 (Appendix B). The unmined stands primarily originated during extensive clearcutting at the turn of the century (Brooks 1910), but also included stands that were closer in age to mineland stands. The latter were abandoned homesteads and a former mining company town that existed as early successional vegetation at the time the 1945 photos were taken.

The seams from which coal was extracted at mine sites included: the Middle War Eagle coal in the Kanawha Formation and the Fire Creek coal and Sewell coal in the New River 
Formation. The Kanawha, New River, and Pocahontas formations constitute the Pottsville Group (Pennsylvania Period) and contain a series of interbedded coal-bearing sandstones, siltstones, and shales (Barlow 1974). Mine sites were not planted with trees with the exception of a 0.4 ha section of pitch pine on the Sewell Knob mine and a row of white pine 150 meters long on the Turkey Spur mine.

Point count transect layout was accomplished in ArcGIS. I delineated minelands using aerial photographs and randomly generated sampling points (Hawth"es Analysis Tools; Beyer 2004) within an area that extended from $20 \mathrm{~m}$ upslope to $20 \mathrm{~m}$ downslope of the mine. At two sites, the area above the highwall could not be sampled safely so I excluded these particular areas prior to generating points.

Adjacent to each mined transect, I delineated an area of unmined forest. I attempted to match each unmined area to the adjacent mined transect with respect to aspect, slope position, and size large enough to encompass a similar number of sampling points. Within each area of unmined forest, I randomly generated sampling points using Hawth ${ }^{\text {ee }}$ Analysis Tools (Beyer 2004). Both mined and unmined points were separated by at least $250 \mathrm{~m}$ and unmined points were $>100 \mathrm{~m}$ from mines. Although the study area contains largely unfragmented forest, a variety of small, anthropogenic disturbances occur throughout, including narrow forest roads, isolated homes, narrow powerline corridors, and patches of early-successional vegetation on abandoned homesites. All points were placed at least $85 \mathrm{~m}$ from these disturbances.

In 2010, I sampled avian assemblages at 17 points in unmined plateau forest, 17 points along loose-dumped benches, 17 points in unmined, steep slope forest, and 14 points along compacted benches. In total, I surveyed 31 points at mined sites and 34 points at unmined sites.

Bird surveys. Between 1/2 hour after sunrise and 1045 AM from 16 May through 2 June, I sampled breeding bird communities using variable circular plot point counts. I conducted ten minute counts and sampled each point twice (Petit et al. 1995) with approximately one week between counts. Observations were categorized into five detection types: singing, calling, displaying or drumming, flyovers, and visuals. I used a laser rangefinder to obtain radial distances to each bird that was detected with the exception of flyovers. Distances were assigned to the following categories: 0-10 m, 11-20 m, 21-30 m...91-100 m, 101-125 m, 126-150 m, and $>150 \mathrm{~m}$. Detections were recorded into four time intervals: 0-3 minutes, $>3-5$ minutes, $>5-8$ minutes, and $>8-10$ minutes. 
Distance analysis. Heterogeneity in detectability between habitats can introduce bias in estimates of density that if unmodeled may lead to erroneous inferences about populations (Diefenbach et al. 2003, Kissling and Garton 2006, Simons et al. 2006). Distance sampling is a method used in concert with randomized line and point transect surveys for the purpose of applying a correction factor (detection function) to raw count data and thereby removing bias from estimates of density (Thompson 2002). Assumptions within distance sampling are: 1) detection at zero distance has probability 1.2) animals are detected instantaneously and prior to evasive movement or attraction in response to observers, and 3) distances are measured accurately. In studies of forest songbirds, these assumptions are often incompletely met at some level (Kissling and Garton 2006).

Mineland topography and variation in habitat structure between mined and unmined forest were potential sources of detection heterogeneity. Therefore, I evaluated whether detectability differed between mined and unmined forest by modeling detection functions for as many species as sample size would allow. For three species with $>60$ singing detections within both mined and unmined stratums, I fit a separate detection function to data within each stratum using conventional distance sampling (CDS) (Buckland et al. 2001). For four species in which sample size was inadequate for stratification but for which there were at least 60 total singing detections, I modeled the detection function for the pooled data as a function of covariates that I assumed to have created heterogeneity in detectability (multiple covariate distance sampling (MCDS)) (Marques et al. 2007). I then used post-stratification to obtain separate detection functions for mined and unmined forest. Covariates included slope type (plateau or steep slope), percent slope, vertical foliage density, subcanopy cover (0-6 m), midcanopy cover ( $>6-18 \mathrm{~m})$, overstory cover ( $>18 \mathrm{~m}$ ), small trees (trees $<23 \mathrm{~cm} \mathrm{dbh}$ ), large trees (trees $\geq 23 \mathrm{~cm} \mathrm{dbh}$ ), and sapling density. Values for covariates were the sum or mean (as appropriate) of data collected at three vegetation plots per point. Prior to analysis, I truncated $5-10 \%$ of a species ${ }^{e e}$ furthest observations to remove outliers (Buckland et al. 2001).

I modeled detection functions within Program Distance (Thomas et al. 2009) through selection from two key functions (half-normal and hazard-rate) with incorporation, given that model fit was improved, of cosine or simple polynomial series expansion terms (Buckland et al. 2001). I used Akaike s Information Criterion (AIC), visual inspection of detection function and 
probability density histograms, and Chi-squared goodness-of-fit tests to select between models and to assess model fit (Buckland et al. 2001).

Estimates of the effective detection radius (EDR) and their $95 \%$ confidence intervals indicated that detectability was similar for mined and unmined forest for all seven species that I modeled (Fig. 6). Depending on the function used in the detection model, the EDR estimates the distance at which the probability of detection declines below 0.5 (Laake et al. 1993, Simons et al. 2006).

Due to the aggregated, linear nature of minelands and the limited scale at which I sampled them, distances may not have been independent of bird distribution. For a species that is displaced by mineland forest, the scale at which I sampled minelands would not be sufficient for the distribution of distances to reflect independence from the location of my sampling points (Marques 2007). For this reason as well as the absence of strong differences in detectability between mined and unmined forest, I did not correct raw counts. For analyses, I used a species ${ }^{\text {ee }}$ maximum count between the two visits to each station.

Habitat sampling. I sampled habitat structure and composition using methods similar to Wood et al. (2001) that were modified from James and Shugart (1970) and the Breeding Bird Research Database Program (BBIRD; Martin et al. 1997). At a distance of 50 meters from each point count station, I established three habitat sampling plots along bearings separated by 120 degrees, the first of which was generated randomly. Within plots, I identified all trees $>8 \mathrm{~cm}$ diameter at breast height ( $\mathrm{dbh}$ ) to species and measured dbh. I tallied all vines that reached the canopy on measured trees and counted all snags $>8 \mathrm{~cm}$ dbh and $>8 \mathrm{~m}$ tall. Within each plot, I established two, $22.6 \mathrm{~m}$ perpendicular transects. Using an ocular tube and sighting along the tube $\mathrm{s}$ crosshairs, I estimated vertical foliage density at a total of 20 points, located $2 \mathrm{~m}$ apart along the perpendicular transects. I recorded the presence or absence of live foliage in the crosshairs at heights of 0.5-3 m, >3-6 m, >6-12 m, >12-18 m, >18-24 m, and >24 m. From these data, I calculated vertical foliage density as the sum of all foliage hits divided by the total number of sighting intervals (120) and then multiplied by 100. Foliage density data also were collapsed into understory (0-6 m), midstory (.6-18 m), and overstory (>18 m) layers.

Within 3 m-radius subplots at the center of each 0.04 ha plot, I counted woody vegetation 0.5-1.5 $\mathrm{m}$ tall (shrubs) and tallied saplings ( $>1.5 \mathrm{~m}$ tall and $<8 \mathrm{~cm} \mathrm{dbh})$ and downed logs. I also estimated shrub, sapling, and downed woody debris cover (logs and stumps $>8 \mathrm{~cm} \mathrm{dbh}$ and $>1 \mathrm{~m}$ 
in length). Using a $1 \mathrm{~m}$ DEM, I calculated mean percent slope within a 50-m radius of each point.

\begin{abstract}
ANALYSES
Non-metric multidimensional scaling (NMDS) was used to visualize patterns in avian assemblage structure between mined and unmined habitat types. In NMDS, ordination is based upon preservation of the original rank order of between sample distances derived from a dissimilarity matrix (Clarke and Green 1988, Clarke 1993). In using rank order distances, NMDS avoids the linear distribution assumption (Clarke and Green 1988). Locations of assemblages in the multidimensional space are determined through multiple iterations such that stress is minimized (Clarke and Green 1988). Stress is a measure of goodness of fit between plotted and true rank order distances from the original distance matrix (Clarke and Green 1988).

NMDS was conducted using the „vegan" package (Oksanen et al. 2009) within Program R 2.12.1 (R Development Core Team 2010). I excluded species that individually contributed $<1 \%$ to the total count (Preston and Harestad 2007, Chizinski et al. 2011). Ordination was performed using the metaMDS function and a Bray-Curtis dissimilarity matrix. Data was standardized using the Wisconsin double standardization method and square-root transformed to increase the relative importance of less abundant species. Multiple random starts (20/ordination) were performed in order to avoid becoming trapped in local minima (the iterative process stalling at a stress value that actually can be further reduced) (McCune and Grace 2002). NMDS was conducted in dimensions 2-6. The stress of NMDS ordinations was evaluated against their dimensionality via a screeplot to determine the appropriate dimensionality for display and statistical testing. Habitat type was overlaid and species were ordinated by their averaged weighted scores.
\end{abstract}

I used the adonis function (vegan package; Oksanen et al. 2009) to statistically assess the variation in assemblage structure attributable to forest type (mined and unmined), slope type (plateau and steep slope), and the interaction between forest type and slope class. This function performs a multivariate analysis of variance through partitioning of the sums of squares in a distance matrix in relation to a factor and using $F$-tests from permutations of the data to determine the level of statistical significance (Oksanen et al. 2009). I used the adonis method rather than analysis of similarities (ANOSIM) because the adonis method is generally considered 
more robust than ANOSIM (Oksanen et al. 2009). I used a Bray-Curtis dissimilarity matrix and specified that permutations (999) occurred within sites but not across sites (Oksanen et al. 2009).

A mean dissimilarity dendrogram was then used to graphically display mean betweengroup and within-group dissimilarity. To determine the appropriate linkage method, cophenetic correlations were calculated between the original Euclidian distance matrix and a Bray-Curtis distance matrix using both "average" and "single" linkage methods (Oksanen et al. 2009). I used the average linkage method because this linkage in combination with a Bray-Curtis metric produced a higher cophenetic correlation (0.22) than did the single linkage method (0.18).

Within the mean dissimilarity dendrogram, vertical lines indicate mean within-group dissimilarity; longer lines equate to lower mean dissimilarity (Oksanen et al. 2009). The horizontal line indicates mean between-group dissimilarity (Oksanen et al. 2009).

Using generalized linear modeling (GLM), I tested for differences in species richness, overall abundance, and abundance within foraging, nesting, and habitat guilds. Modeling was a function of forest type (mined and unmined), slope type (plateau and steep slope), the interaction between forest type and slope class, and site, all as fixed effects. I evaluated models for overdispersion using a Poisson GLM and an associated dispersion parameter. Based on the absence of overdispersion in all models, I determined a Poisson distribution was appropriate for these analyses (Zuur et al. 2009). Statistical significance was assessed via an analysis of deviance test in which the difference in deviance approximately follows a Chi-square distribution with 1 degree of freedom (Zuur et al. 2009). Foraging and nesting guilds were adapted from Ehrlich et al. (1988) and Canterbury et al. (2000) (Appendix C). I placed species into habitat guilds (closed canopy species, broken canopy species, and forest generalists) in the context of the canopy disturbance gradient that exists within the study area (contiguous forest with relatively small areas of broken canopy habitat). In addition, I tested for differences in Shannon ( $\left.H^{\prime}\right)$ diversity using a Gaussian distribution and the model specification previously described.

For analysis of habitat variables, vegetation sampling plots were classed as unmined plateau, loose-dumped bench, unmined steep slope, and compacted bench. I used a subset of plots associated with mined point counts that was comprised of only those plots that were wholly on the mine. I included all plots associated with unmined plateau and steep slope point count stations. I retained all variables for analysis with the exception of those pertaining to subcanopy characteristics (shrubs, saplings, downed logs) for which I had recorded both density and cover; I 
only included one or the other in all three cases. I graphically evaluated whether data for each habitat variable met assumptions of normality and variance homogeneity. Cover variables not meeting these assumptions were arcsine-transformed. Count data not meeting these assumptions were square root-transformed. I compared variables between the four habitat types using univariate analysis of variance with multiple comparisons using Tukey"s HSD procedure. Using 0.05 as the global alpha level, the critical $p$-value was set at 0.0036 using the Bonferroni method.

\section{RESULTS}

Habitat summary. Compacted bench sites had characteristics indicative of disturbed forests including significantly greater canopy vine density and midcanopy foliage density relative to the three other habitat types (Table 1). Also, overstory foliage density was significantly lower than loose-dumped bench sites and unmined, steep slope sites. Within compacted bench sites, high midcanopy cover and low overstory cover suggests lower canopy height overall (Fig. 7).

Unmined plateau sites were characterized by comparatively greater subcanopy and midcanopy development. Shrub density was significantly higher than the other three habitat types and small tree $(8-23 \mathrm{~cm})$ density was significantly higher than loose-dumped bench sites and unmined, steep slope sites (Table 1). In contrast, loose-dumped bench sites had significantly lower subcanopy foliage density than unmined plateau sites and compacted bench sites (Fig. 7).

Within compacted bench and loose-dumped bench minelands, yellow poplar and red maple were predominant (Appendix G). Unmined plateau sites were dominated by red maple and non-mesic oaks: scarlet, white, chestnut, and black oak. Within unmined, steep slope sites, red maple, sugar maple, and northern red oak were predominant.

Avian assemblage structure. In evaluating the stress of NMDS ordinations versus their dimensionality, stress was not appreciably reduced for ordinations with greater than three dimensions. Thus, samples are plotted within the first two dimensions of the 3-dimensional NMDS solution (Fig. 8). Stress for the 3-dimensional NMDS solution was 20.6 (two convergent solutions after 6 runs).

The NMDS ordination showed overlap between assemblages associated with all four habitat types. Only compacted bench sites showed some discrimination from other habitat types, but there was not clear separation of these assemblages. Compacted bench assemblages were 
primarily clustered on the left side of the plot and were discriminated by Worm-eating Warbler (Helmitheros vermivorus), Rose-breasted Grosbeak (Pheucticus ludovicianus), and American Redstart (Setophaga ruticilla).

The mean dissimilarity dendogram (Fig. 9) indicated greater between-group dissimilarity than within-group dissimilarity for all habitat types. However, group structure was not particularly strong as evidenced by mean between-group dissimilarity $(\mathrm{Bbar}=0.502)$ relative to mean within-group dissimilarity (Wbar $=0.453)$. Among the four assemblage types, compacted bench and unmined steep slope assemblages had the highest within-group dissimilarity.

The adonis analysis indicated that assemblage structure differed significantly between mined and unmined forest and between steep slope and plateau sites (Table 2). However, in modeling both of these effects, variation in within-group distances was overwhelming and forest and slope type accounted for only $6.0 \%$ and $8.8 \%$ of the variation in the avian assemblage, respectively. The interaction between forest type and slope type was marginally significant and accounted for only $2.6 \%$ of the variation in the avian assemblage.

Overall relative abundance, abundance within nesting and foraging guilds, species richness, and Shannon $\left(H^{\prime}\right)$ diversity were similar for mined and unmined forest (Table 3 ). Mined and unmined forest had similar abundance of broken canopy and forest generalist species (Fig. 10), but closed-canopy species had significantly greater abundance within unmined forest (Table 3). The interaction between forest type and slope type was non-significant for all analyses.

\section{DISCUSSION}

The presence of pre-SMCRA minelands with loose-dumped benches was not a strong influence on avian assemblage structure. Only compacted bench minelands had a relatively distinct avian assemblage. However, within the NMDS ordination, this assemblage was not discrete, suggesting that these minelands modify the avian assemblage on a relatively narrow scale. Dense midcanopy cover and relatively low levels of overstory cover characterized compacted bench minelands. These characteristics result in part from poor physical and chemical properties of minesoils which have arrested forest development along benches. Canopy vine density, primarily grapevine (Vitis spp.), was substantially higher within compacted bench sites and suggested that forest development also may be restricted through vine-capture of the habitat. 
In addition to the structure of this restricted forest and vine community, dense understory vegetation and canopy foliage along the highwall edge and the young forest habitat that originated through highwall collapse were likely influential in structuring avian assemblages along compacted benches.

Species which use the subcanopy and midcanopy for nesting and foraging, American Redstart, Rose-breasted Grosbeak, and Worm-eating Warbler, differentiated the avian assemblage associated with compacted bench minelands. American Redstart and Rose-breasted Grosbeak are generally most abundant within mesic, second growth forest in which some shrubby vegetation is present (Wyatt and Francis 2002, Sherry and Holmes 1997). Worm-eating Warblers are associated with dense understory vegetation usually along steep slopes (Hanners and Patton 1998).

Relative abundance of the closed-canopy guild was significantly higher within unmined forest. For some mature forest-restricted species, i.e. Blue-headed Vireo and Ovenbird, mineland habitats may have low suitability due to relatively low subcanopy cover within loose-dumped bench sites and relatively low overstory cover and canopy height along compacted benches. Blue-headed Vireos are generally associated with high canopy closure, usually $>75 \%$, but also use the subcanopy extensively for foraging and nesting (Hamel 1992, Meehan 1996, James 1998). In addition, mineland forests may represent suboptimal breeding habitat for Ovenbirds, a ground-nesting and foraging species, due to relatively low leaf litter depth and cover and high forb cover (Mizel, unpublished data).

Previous research has illustrated the significant effect that large-scale surface mining has on mature forest songbirds, Cerulean Warblers (Dendroica cerulea) in particular (Wood et al. 2006). Few studies have investigated the influence of forested pre-SMCRA surface mines on the avian assemblage. This study has shown that compacted bench minelands created significant habitat contrast with the surrounding, unmined forest and consequently resulted in a relatively distinct avian assemblage. 


\section{Literature Cited}

Barlow, J.A., 1974. Coal and coal mining in West Virginia. Coal Geology Bull. No. 2. West Virginia Geological and Economic Survey, Morgantown, WV

Beyer, H.L. 2004. Hawth"s analysis tools for ArcGIS. http://www.spatialecology.com/htools

Brooks, A.B. 1910. West Virginia Geological Survey, Volume Five: Forestry and Wood Industries. The Acme Publishing Company, Morgantown, WV

Brown, J.H. 1962. Success of tree planting on strip-mined areas in West Virginia. West Virginia University Agricultural Station Bulletin 473.

Buckland, S. T., D. R. Anderson, K. P, Burnham, J. L. Laake, D. L. Borchers, and L.Thomas. 2001. Introduction to distance sampling: estimating abundance of biological populations. Oxford University Press, New York, NY, USA.

Burke, D. M. and E. Nol. 1998. Influence of food abundance, nest-site habitat, and forest fragmentation on breeding Ovenbirds. Auk 115: 96-104.

Canterbury, G. E., Martin, T. E., Petit, D. R., Petit, L. J. and Bradford, D. F.: 2000. Bird communities and habitat as ecological indicators of forest condition in regional monitoring. Conserv. Biol. 14:544-558.

Chizinski, C.J., Peterson, A., Hanowski, J., Blinn, C.R., Vondracek, B., and Niemi, G. 2011. Breeding bird response to partially harvested riparian management zones. Forest Ecology and Management 261:1892-1900.

Clarke, K. R. 1993. Non-parametric multivariate analyses of changes in community structure. Australian Journal of Ecology 18:117-143.

Clarke, K. R., and R. H. Green. 1988. Statistical design and analysis for a ,biological effects $^{\text {ee }}$ study. Marine Ecology Progress Series 46: 213-226.

Diefenbach, D. R., Brauning, D. W., and Mattice, J. A. 2003. Variability in grassland bird counts related to observer differences and species detection rates. Auk 120: 1168-1179.

Ehrlich, P. R., Dobkin, D. S., and D. Wheye. 1988. The Birderes Handbook, Simon and Schuster, New York.

Hamel, P. B. 1992. The land manager's guide to the birds of the South. The Nature Conservancy, Chapel Hill, North Carolina, USA.

Hanners, L. A., and S. R. Patton. 1998. Worm-eating Warbler (Helmitheros vermivorum), The Birds of North America Online (A. Poole, Ed.). Ithaca: Cornell Lab of Ornithology; 
Retrieved from the Birds of North America Online:

http://bna.birds.cornell.edu/bna/species/367

James, F. C. and H. H. Shugart. 1970. A quantitative method of habitat description. Audubon. Field Notes 24:727-736.

James, R. D. 1998. Blue-headed Vireo (Vireo solitarius), The Birds of North America Online (A. Poole, Ed.). Ithaca: Cornell Lab of Ornithology; Retrieved from the Birds of North America Online: http://bna.birds.cornell.edu/bna.html/species/379

Kissling, M. L., and E. O. Garton. 2006. Estimating detection probability and density from point count surveys: A combination of distance and double-observer sampling. Auk 123: 735752 .

Laake, J.L., Buckland, S.T., Anderson, A.D., and K.P. Burnham. 1993. Distance User"s Guide. Cooperative Fish \& Wildlife Research Unit, Colorado State University, Fort Collins, CO.

McCune, B. and J. B. Grace. 2002. Analysis of ecological communities. MjM Software Design, Gleneden Beach, Oregon.

Marques, T.A., Thomas, L., Fancy, S.G., and S.T. Buckland. 2007. Improving estimates of bird density using multiple covariate distance sampling. Auk 124: 1229-1243.

Martin, T.E., C. Paine, C.J. Conway, W. M. Hockachka, P. Allen, and W. Jenkins. 1997. BBIRD Field Protocol. USGS, Biological Resources Division, Montana Cooperative Fish and Wildlife Research Unit, Missoula, Montana.

Matlack, G. R. 1993. Microenvironment variation within and among forest edge sites in the eastern United States. Biological Conservation 66: 185-194.

Meehan, A.L. 1996. Impacts of group selection harvest openings on the reproductive success of the Solitary Vireo (Vireo solitarius alticola). Master"s Thesis. Virginia Polytechnic Institute and State University, Blacksburg, Virginia, 114 pp.

Oksanen, J., Kindt, R., Legendre, P., O"Hara, B., Simpson, G.L., Solymos, P., Stevens, M. H. H., and $\mathrm{H}$. Wagner. 2009. vegan: community ecology package. $\mathrm{R}$ package version $1.15-2$. $\mathrm{R}$ Foundation for Statistical Computing, Vienna, Austria. (Available from: http://cran.rproject.org/, http://vegan.r-forge.r-project.org)

Petit, D. R., L.J. Petit, V. A. Saab, and T. E. Martin. 1995. Fixed-radius point counts in forests: factors influencing effectiveness and efficiency. Pages 49-56 in Ralph, C. J., J. R. Sauer, and S. Droege, Eds. Monitoring bird populations by point count. U.S. D. A. Forest Service General Technical Report PSW-GTR-149.

Preston, M.I., and A.S. Harestad. 2007. Community and species response by birds to group retention in a coastal temperate forest on Vancouver Island, British Columbia. Forest 
Ecology and Management 243:156-167.

R Development Core Team. 2010. R: A language and environment for statistical computing. $\mathrm{R}$ Foundation for Statistical Computing, Vienna, Austria. ISBN 3-900051-07-0, URL http://www.R-project.org.

Sherry, T. W., and R. T. Holmes. 1997. American Redstart (Setophaga ruticilla), The Birds of North America Online (A. Poole, Ed.). Ithaca: Cornell Lab of Ornithology; Retrieved from the Birds of North America Online: http://bna.birds.cornell.edu/bna.html/species/277

Simons, T.R., Shriner, S.A., and G.L. Farnsworth. 2006. Comparison of breeding bird and vegetation communities in primary and secondary forests of Great Smoky Mountains National Park. Biological Conservation 129: 302-311.

Thomas, L., Laake, J.L., Strindberg, S., Marques, F.F.C., Buckland, S.T., Borchers, D.L., Anderson, D.R., Burnham, K.P., Hedley, S.L., Pollard, J.H., Bishop, J.R.B., and T.A. Marques. 2009. Distance 6.0. Release 2, University of St Andrews: Research Unit for Wildlife Population Assessment. http://www.ruwpa.st-and.ac.uk/distance/ [last accessed: October 1, 2008].

Thompson, W. L. 2002. Towards reliable bird surveys: Accounting for individuals present but not detected. Auk 119: 18-25.

Vanderhorst, J., Jeuck, J., and S. C. Gawler 2007. Vegetation classification and mapping of New River Gorge National River, West Virginia. US Dept. of the Interior, National Park Service. Northeast Region, Philadelphia, Pennsylvania.

Villard, M. A., P. R. Martin, and C. G. Drummond. 1993. Habitat fragmentation and pairing success in the Ovenbird (Seiurus aurocapillus). Auk 110: 759-768.

Wood, P.B., J.W. Edwards, and C.A. Weakland. 2001. Terrestrial vertebrate (breeding songbird, raptor, small mammal, herpetofaunal) of forested and reclaimed sites. Final report submitted to EIS steering committee. Morgantown, West Virginia. 149 pp.

Wood, P.B., Bosworth, S.B., Dettmers, R., 2006. Cerulean warbler abundance and occurrence relative to large-scale edge and habitat characteristics. Condor 108(1):154-165.

Wyatt, V. E., and C. M. Francis. 2002. Rose-breasted Grosbeak (Pheucticus ludovicianus), The Birds of North America Online (A. Poole, Ed.). Ithaca: Cornell Lab of Ornithology; Retrieved from the Birds of North America Online: http://bna.birds.cornell.edu/bna\%22\%20target\%3D\%22_top\%22\%20rel\%3D $\% 22$ nofollo w/species/692

Zuur, A. F., E. N. Ieno, N. J. Walker, A. A. Saveliev, and G. M. Smith. 2009. Mixed effects models and extensions in ecology with R. Springer, New York, New York, USA. 
Table 1. Means $( \pm$ SE) for habitat characteristics associated with point counts conducted in 2010 in southern West Virginia. Plots sampled within oak-hickory forest atop the New River Plateau were categorized as loose-dumped benches $(n=33)$ and unmined plateau $(n=51)$. Plots sampled within mixed-mesophytic forest at steep slope sites are categorized as compacted benches $(n=20)$ and unmined, steep slope $(\mathrm{n}=51)$. The critical $p$-value was set at 0.0036 using the Bonferroni adjustment. Means that do not share an uppercase letter are significantly different ( $p<0.05$; Tukey's multiple comparison procedure).

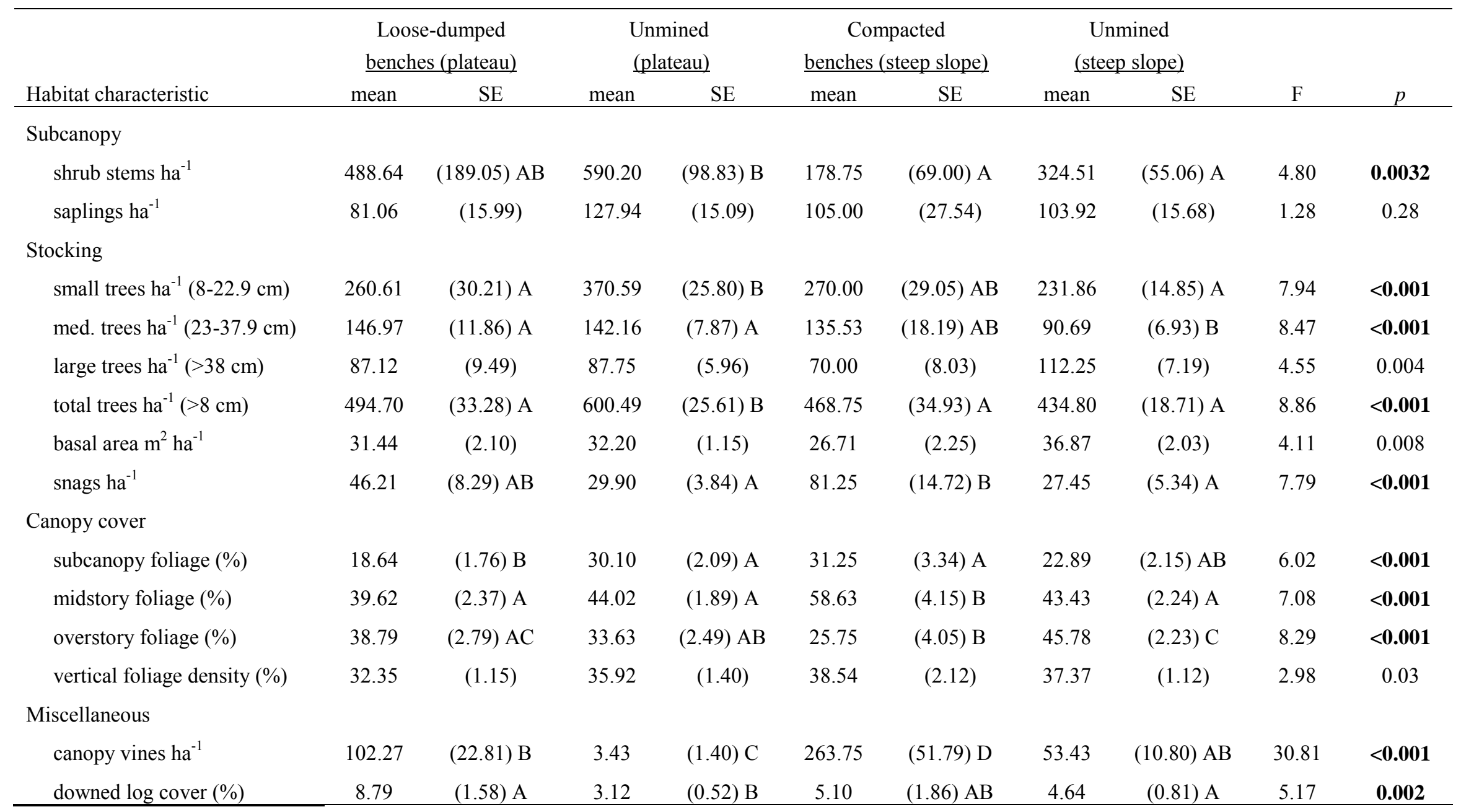


Table 2. Results from adonis analysis of avian assemblage similarity. Partial $R^{2}$ and $p$-values are based on 999 permutations of the data.

\begin{tabular}{lccc}
\hline & $\mathrm{F}_{1,61}$ & $R^{2}$ & $p$ \\
\hline Forest type & 4.44 & 0.060 & 0.001 \\
Slope & 6.46 & 0.088 & 0.001 \\
Forest type x slope & 1.91 & 0.026 & 0.02 \\
\hline
\end{tabular}

Table 3. Mean $( \pm \mathrm{SE})$ relative abundance for all species and habitat, foraging, and nesting guilds at mined and unmined point counts conducted in 2010 in southern West Virginia. Except for Shannon diversity $\left(H^{\prime}\right), p$-values are from Poisson GLMs using an analysis of deviance test in which the difference in deviance approximately follows a Chi-square distribution with 1 degree of freedom. Shannon diversity $\left(H^{\prime}\right)$ was tested with analysis of variance $(*$ indicates the value of the F-statistic).

\begin{tabular}{lcccccc}
\hline & \multicolumn{2}{c}{ Mined } & \multicolumn{2}{c}{ Unmined } \\
& mean & SE & mean & SE & $\chi^{2}{ }_{1}$ & $p$ \\
\hline Diversity $\left(H^{\prime}\right)$ & 2.26 & 0.04 & 2.18 & 0.05 & $0.28^{*}$ & 0.60 \\
Richness & 11.06 & 0.42 & 10.56 & 0.53 & 0.03 & 0.87 \\
All species & 16.58 & 0.59 & 15.91 & 0.64 & 0.00 & 1.00 \\
Habitat guilds & & & & & & \\
$\quad$ closed canopy & 3.29 & 0.25 & 4.76 & 0.36 & 6.88 & 0.009 \\
$\quad$ broken canopy & 2.81 & 0.46 & 1.85 & 0.32 & 0.82 & 0.37 \\
$\quad$ generalists & 10.19 & 0.45 & 9.12 & 0.39 & 2.04 & 0.15 \\
Foraging guilds & & & & & & \\
$\quad$ hawking & 0.97 & 0.18 & 1.12 & 0.16 & 0.23 & 0.63 \\
$\quad$ bark foragers & 1.74 & 0.17 & 2.41 & 0.20 & 2.94 & 0.09 \\
$\quad$ foliage gleaners & 9.52 & 0.44 & 8.41 & 0.49 & 2.10 & 0.15 \\
$\quad$ ground gleaners & 3.81 & 0.30 & 3.59 & 0.29 & 0.20 & 0.66 \\
Nesting guilds & & & & & & \\
$\quad$ subcanopy & 3.16 & 0.47 & 2.03 & 0.26 & 1.00 & 0.32 \\
$\quad$ ground & 3.90 & 0.30 & 4.00 & 0.22 & 0.85 & 0.36 \\
$\quad$ shrub & 1.13 & 0.17 & 0.59 & 0.15 & 1.33 & 0.25 \\
$\quad$ cavity & 1.32 & 0.20 & 2.03 & 0.20 & 3.09 & 0.08 \\
$\quad$ canopy & 6.29 & 0.33 & 6.88 & 0.35 & 4.02 & 0.60 \\
\hline
\end{tabular}



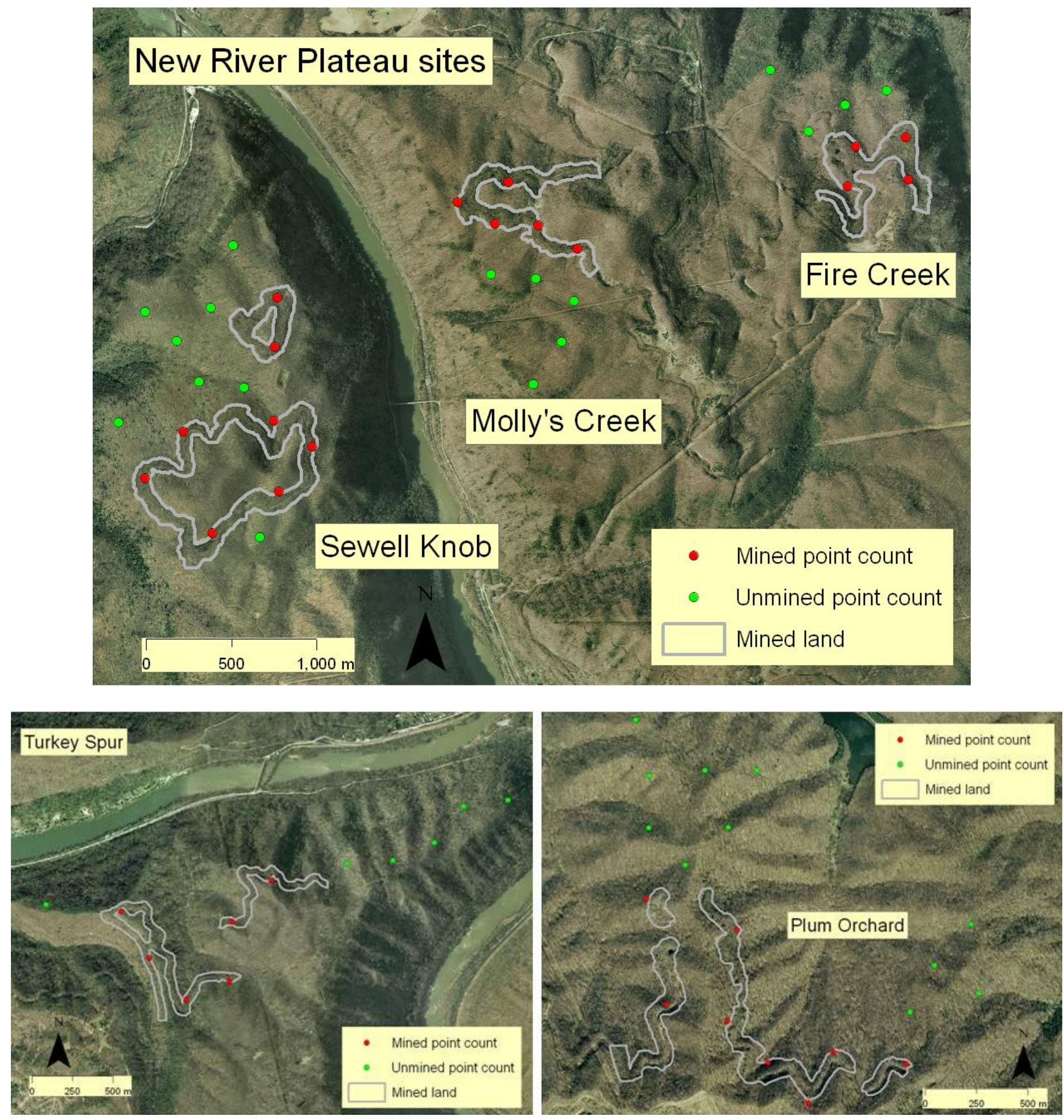

Figure 1. Location of point count stations surveyed in 2010 in southern West Virginia. Plateau study sites (unmined and loose-dumped bench transects) are shown in the top frame and steep slope sites (unmined and compacted bench transects) are shown in the bottom two frames. 


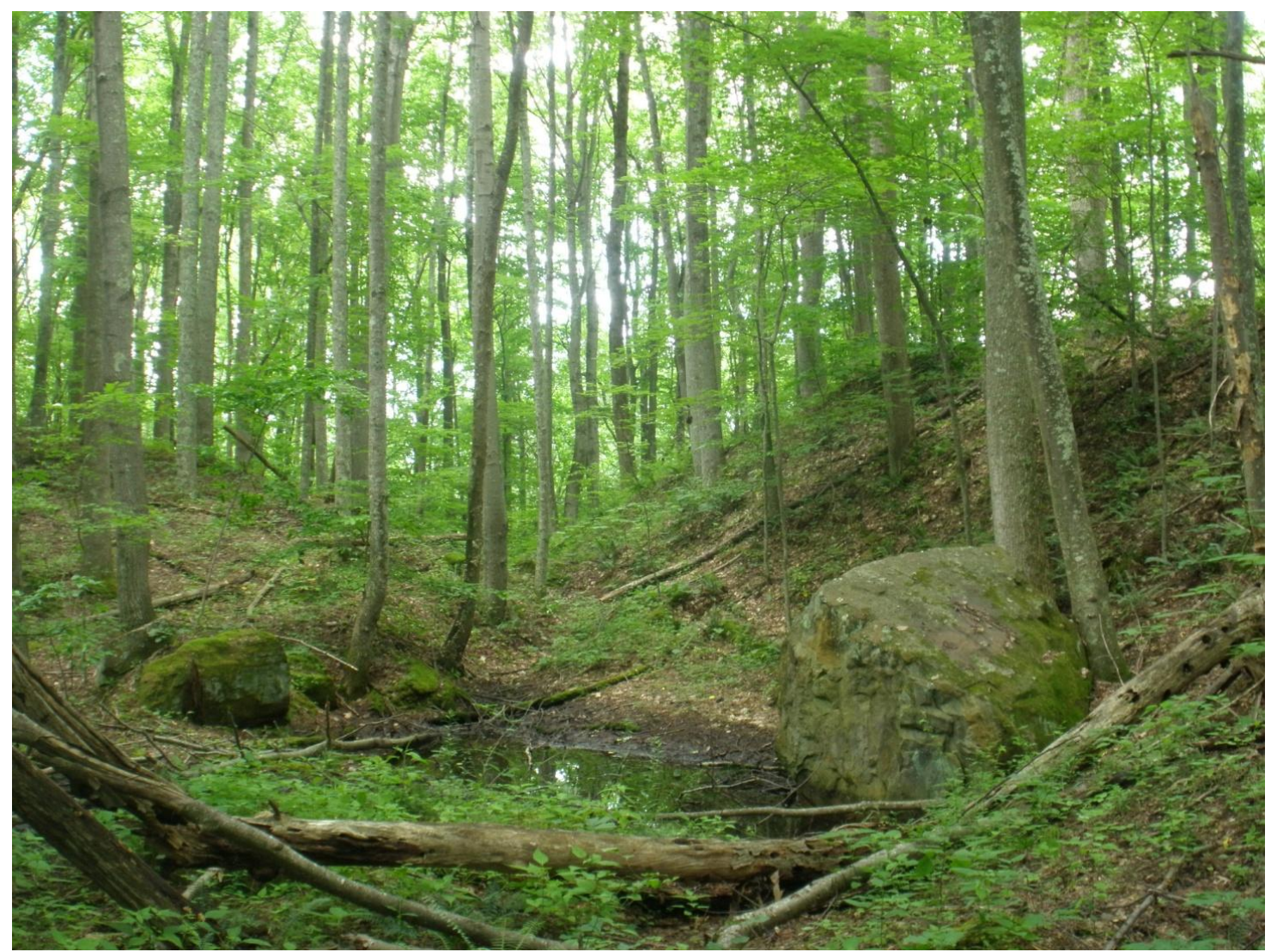

Figure 2. Spoil ridges atop the Fire Creek study site.

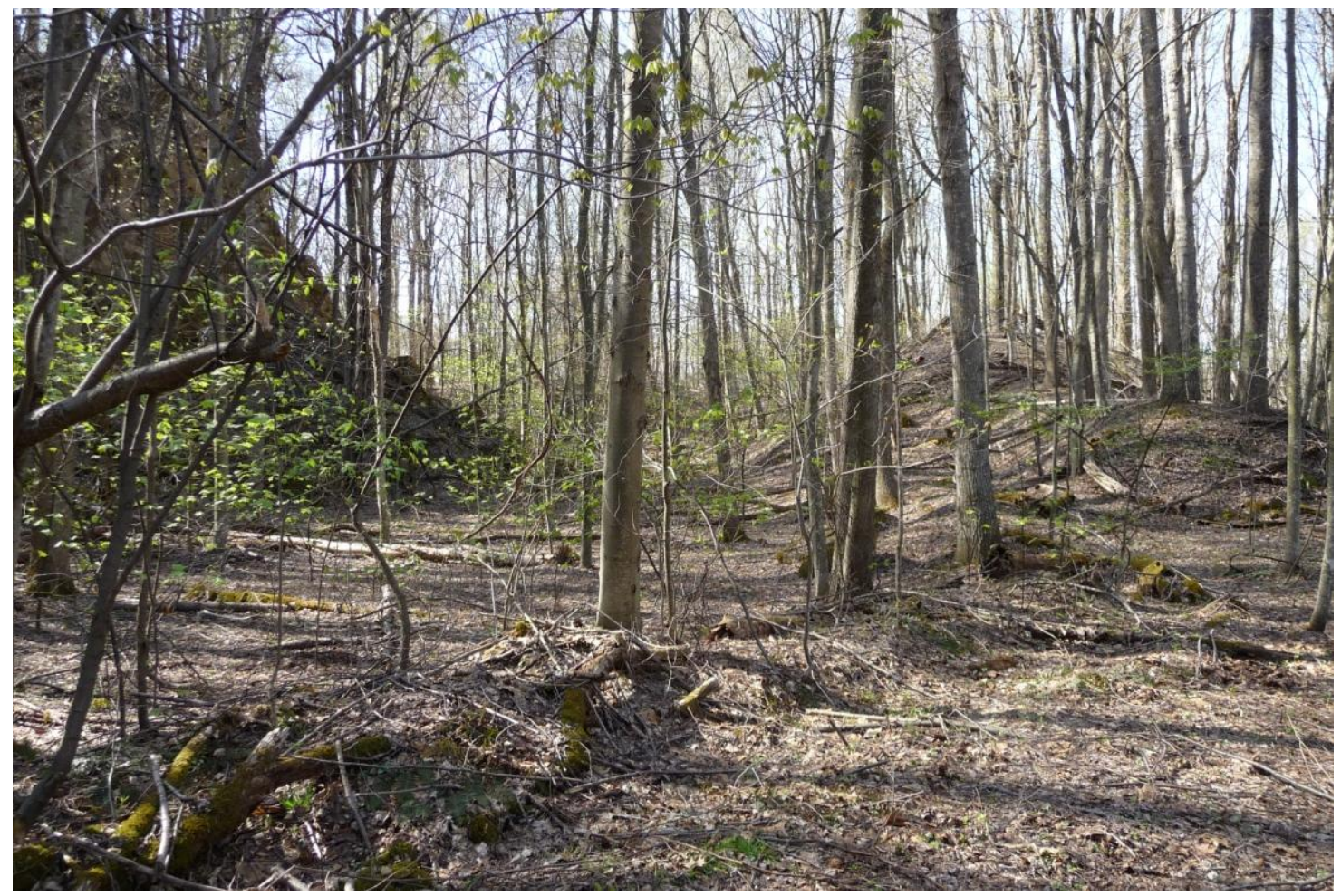

Figure 3. Spoil ridge along Sewell Knob study site. 


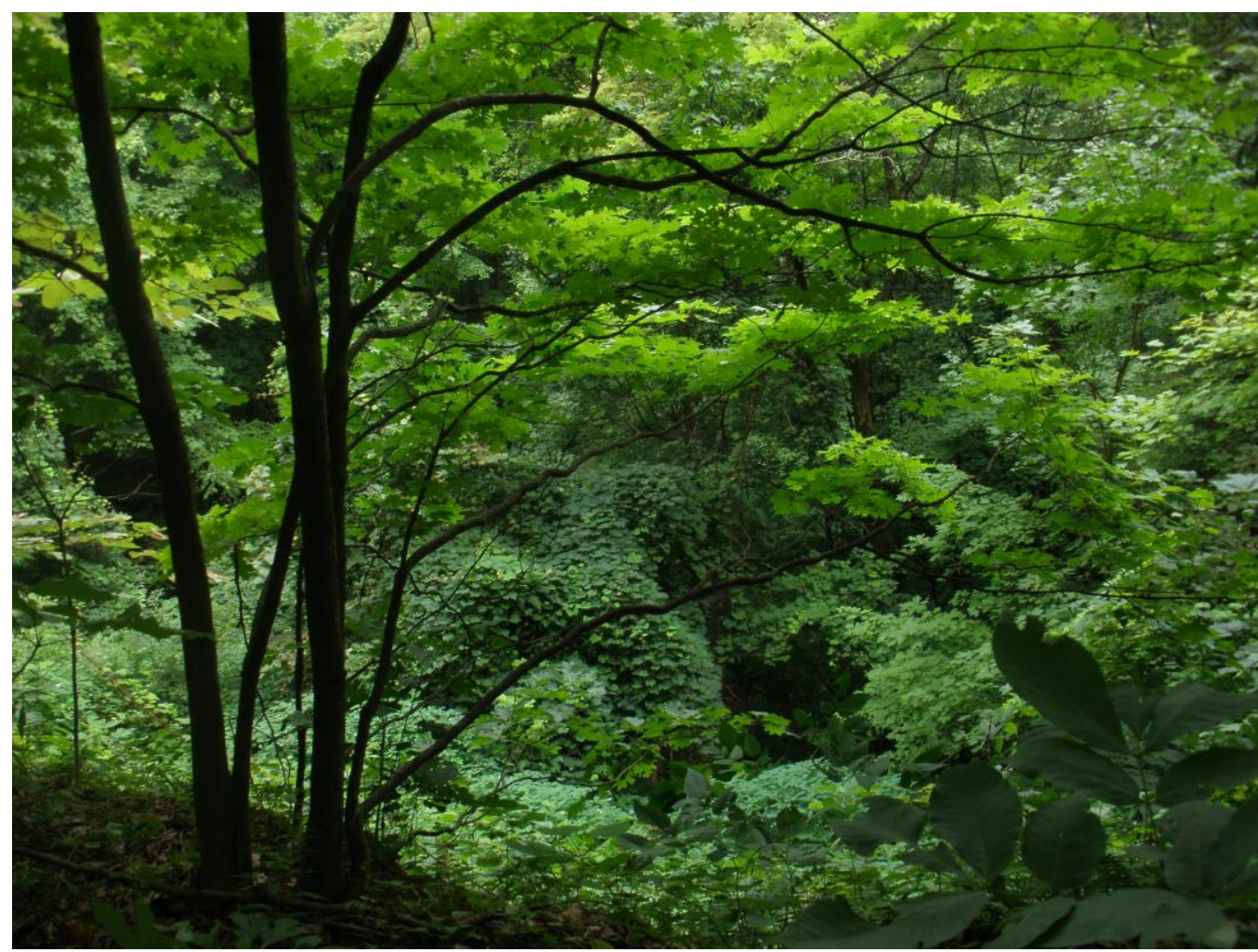

Figure 4. Vine-captured gap at the base of a highwall along a compacted bench study site in Plum Orchard WMA.

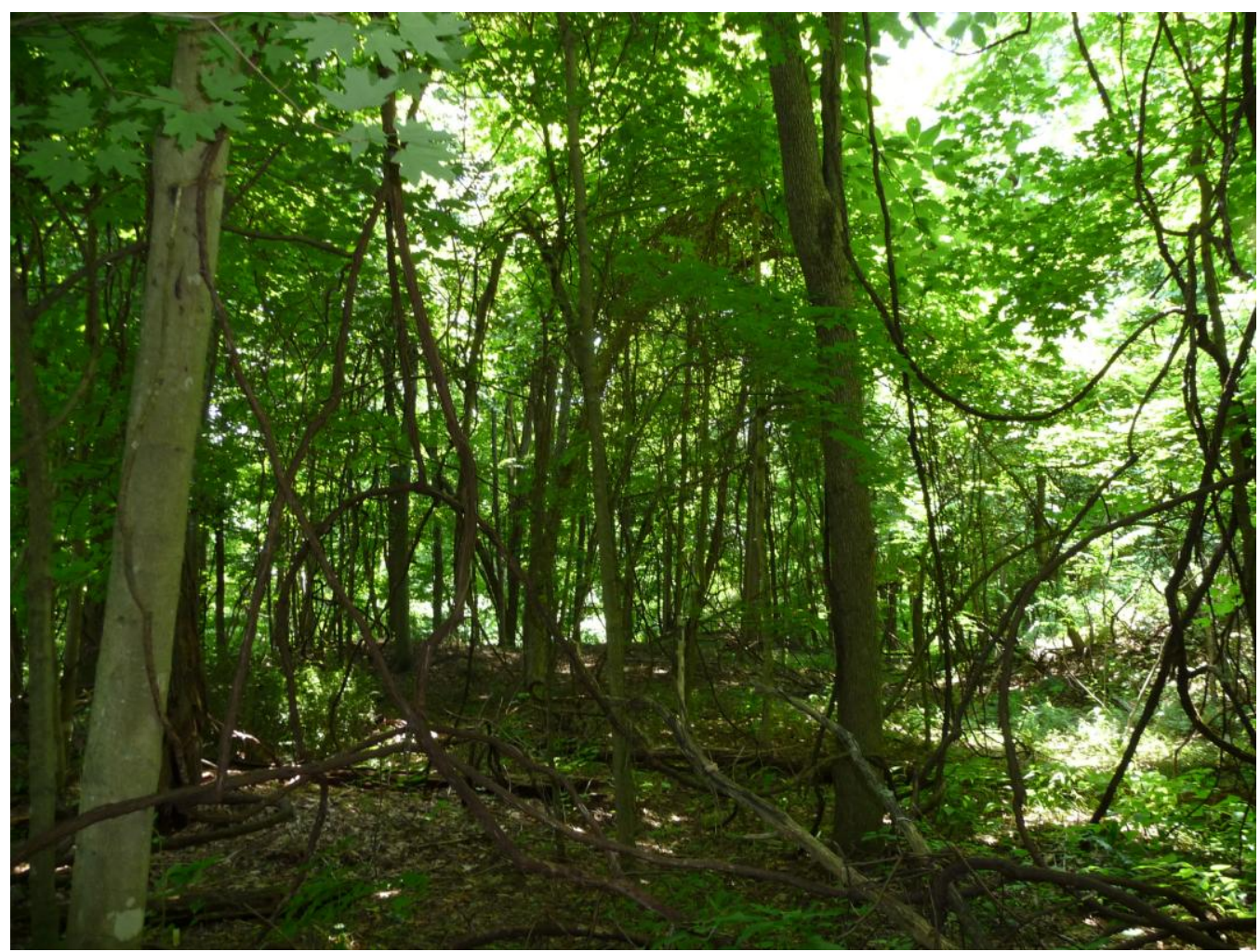

Figure 5. Compacted bench in New River Gorge National River (Turkey Spur study site). 


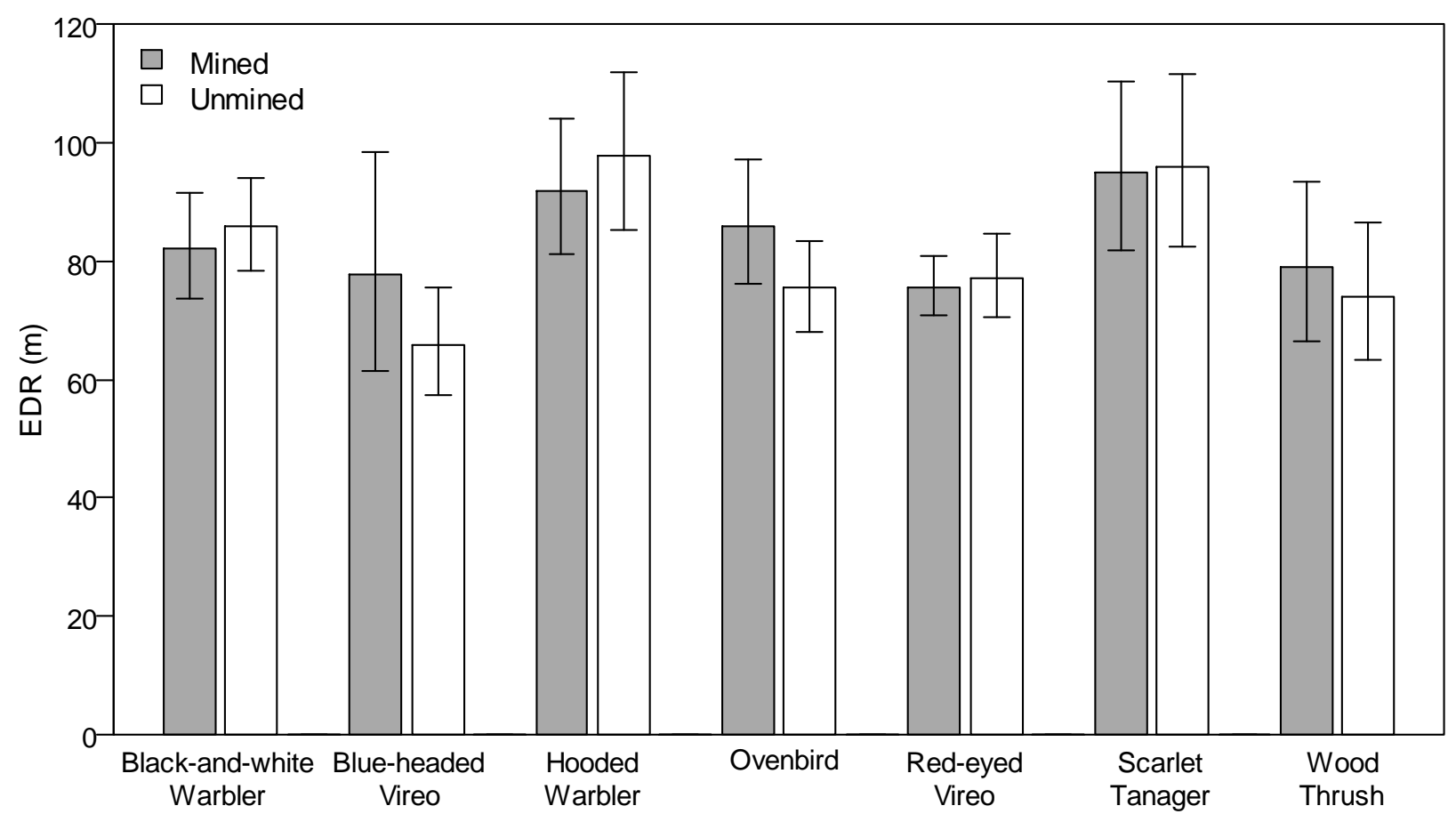

Figure 6. Effective detection radii (EDR) with 95\% confidence intervals for Black-and-white Warbler, Blue-headed Vireo, Hooded Warbler, Ovenbird, Red-eyed Vireo, Scarlet Tanager, and Wood. Estimates are for mined (gray bars) and umined (white bars) point counts. Depending on the function used in the detection model, the EDR estimates the distance at which the probability of detection declines below 0.5 (Laake et al. 1993, Simons et al. 2006). 


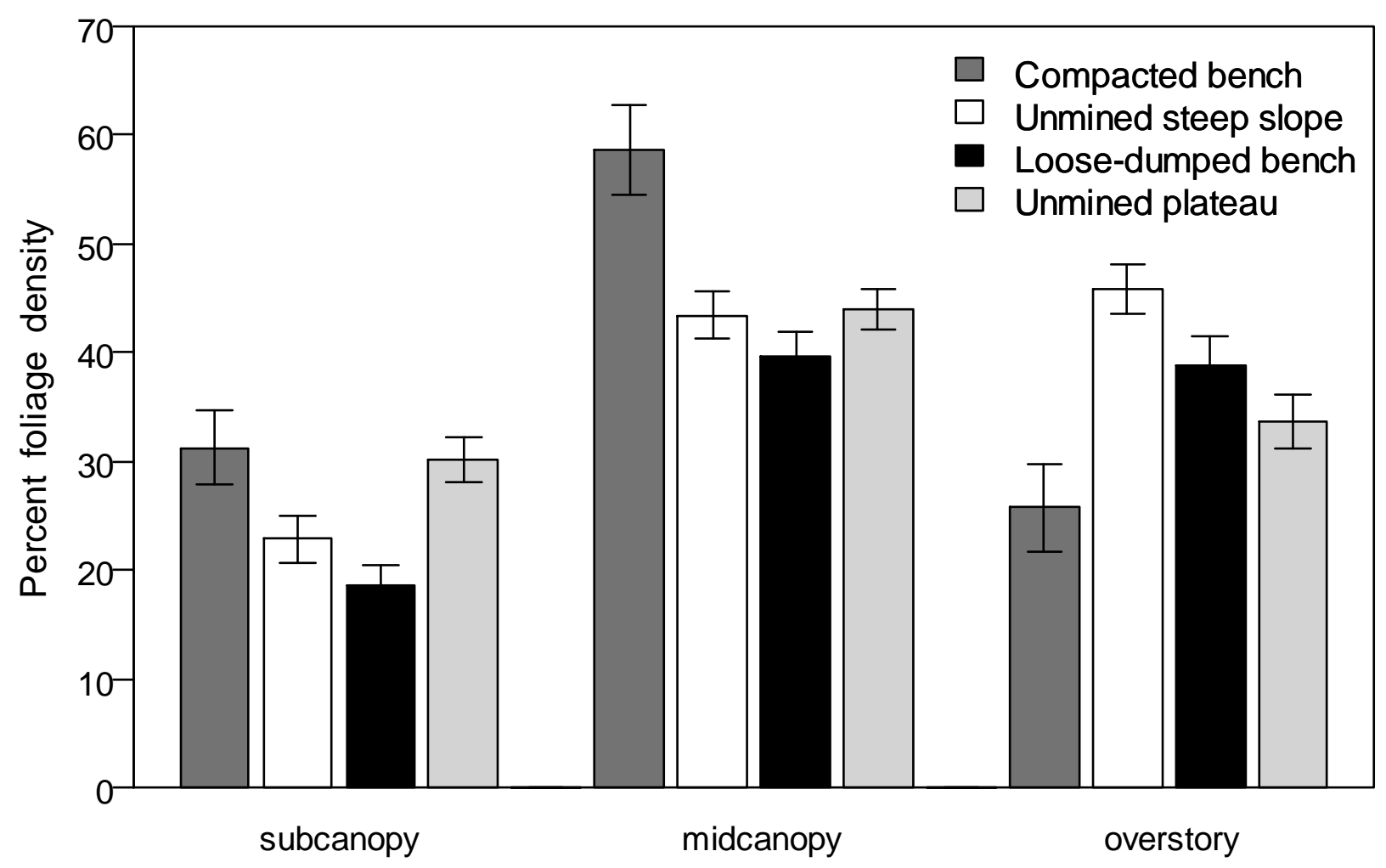

Figure 7. Percent vertical foliage density within the subcanopy (0-6 m), midcanopy (6-18 m), and overstory $(>18 \mathrm{~m})$ for compacted bench sites, unmined steep slope sites, loose-dumped bench sites, and unmined plateau sites. 


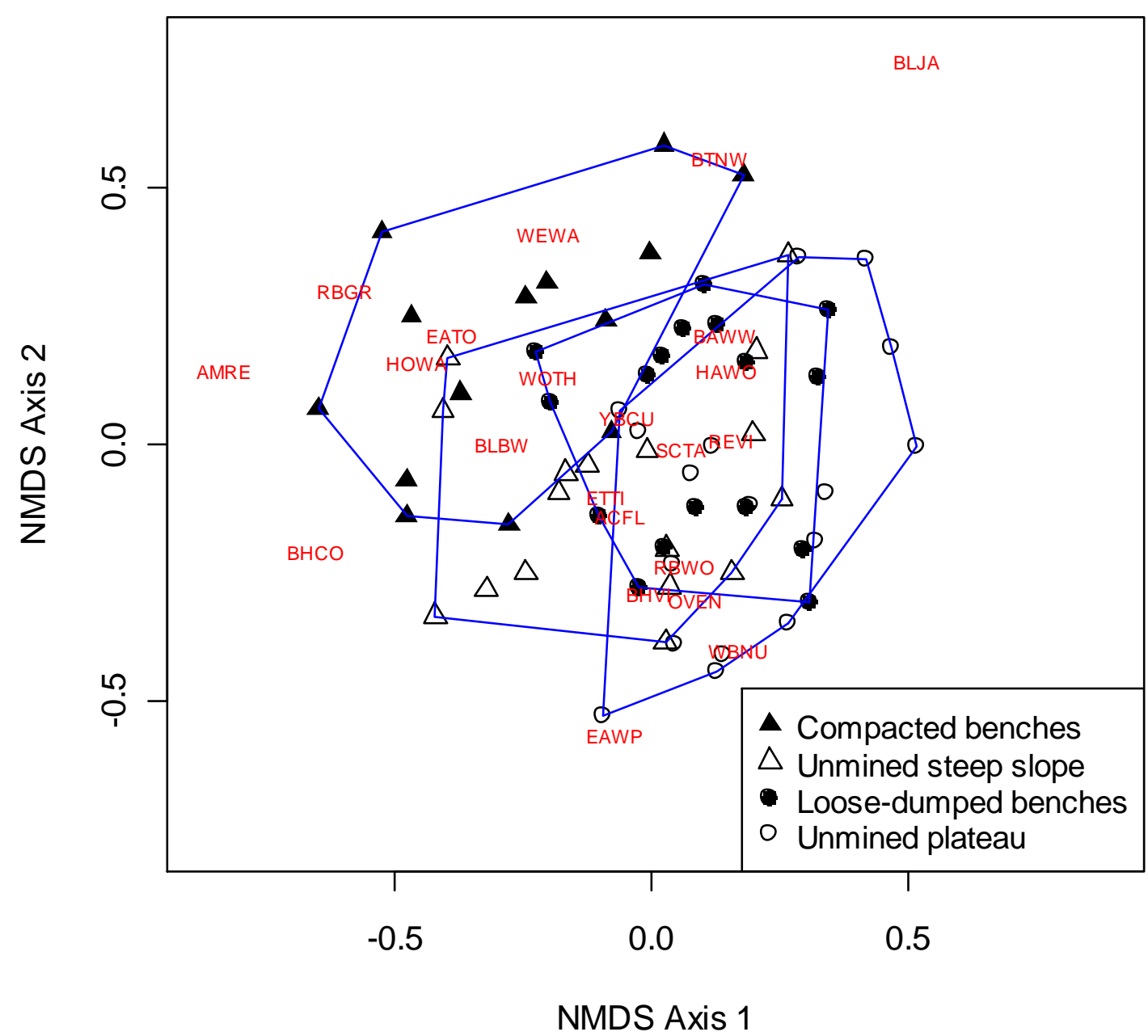

Figure 8. Dimensions 1 and 2 from a 3-dimensional NMDS solution for avian assemblages in mined (compacted and loose-dumped benches) and unmined forest. Stress was 20.6 for the 3dimensional solution ( 2 convergent solutions after 6 runs). Species codes are listed in Appendix C. 


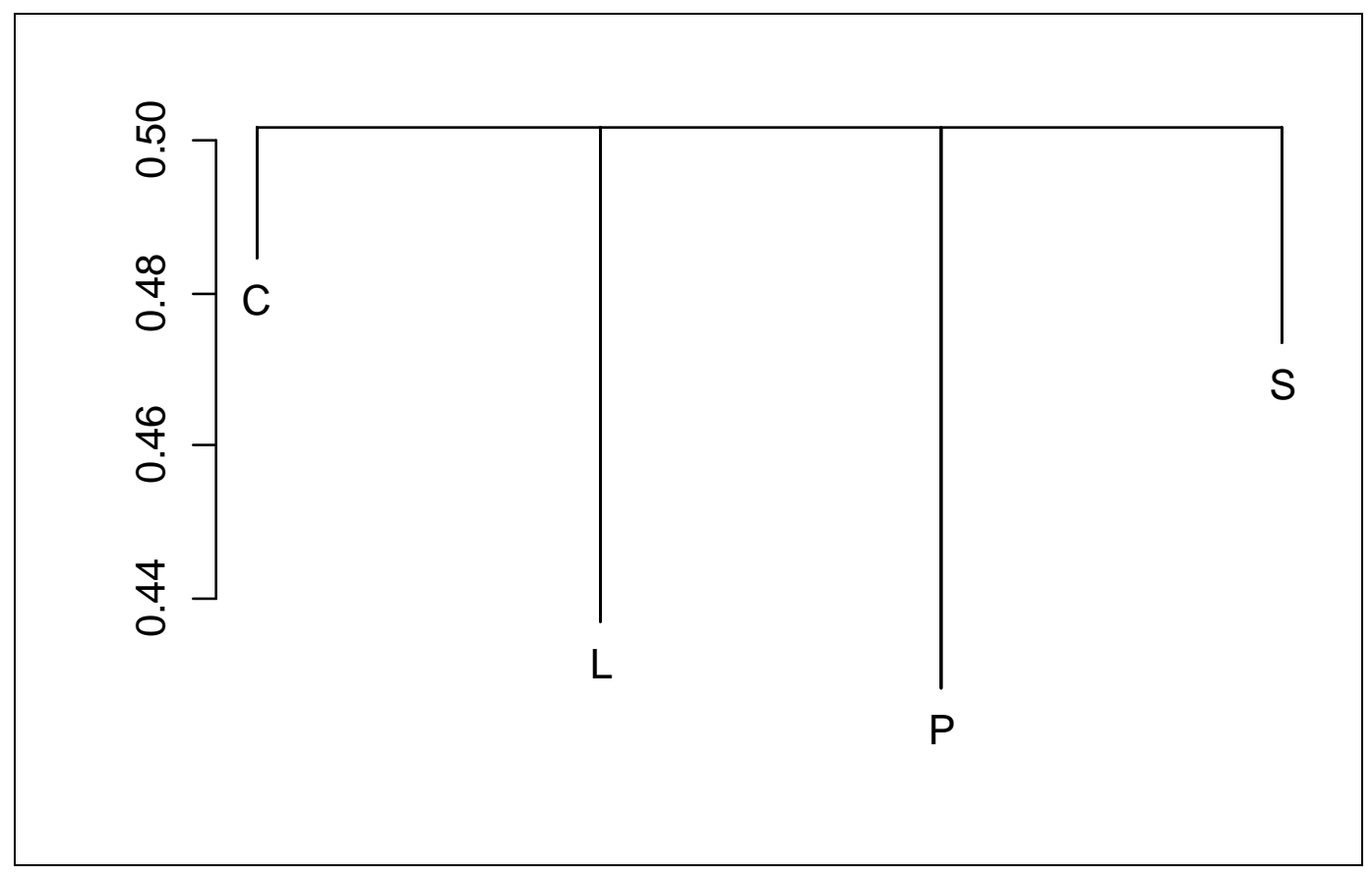

Figure 9. Mean dissimilarity dendrogram for compacted bench assemblages (C), loose-dumped bench assemblages (L), unmined plateau assemblages (P), and unmined steep slope assemblages $(\mathrm{S})$. Mean between-group dissimilarity $(\mathrm{Bbar})=0.502$. Mean within-group dissimilarity (Wbar) $=0.453$. 

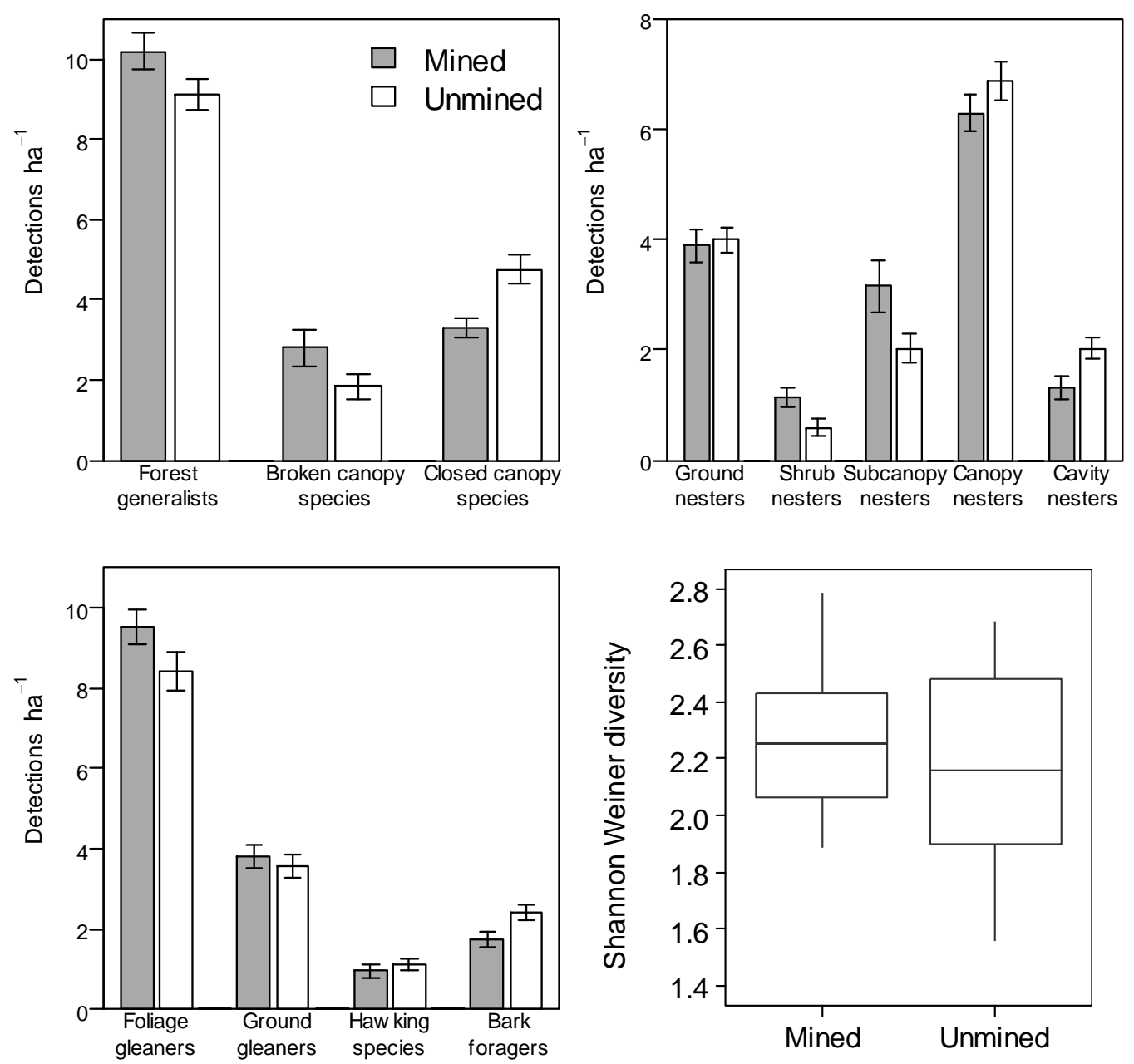

Figure 10. Relative abundance ( \pm SE) for habitat, nesting, and foraging guilds for mined (gray) and unmined (white) point counts. The boxplot for Shannon diversity $\left(H^{\prime}\right)$ is also shown. 
Appendix A. Study area location for line transect surveys and Red-eyed Vireo nest monitoring in New River Gorge National River, West Virginia in 2011.

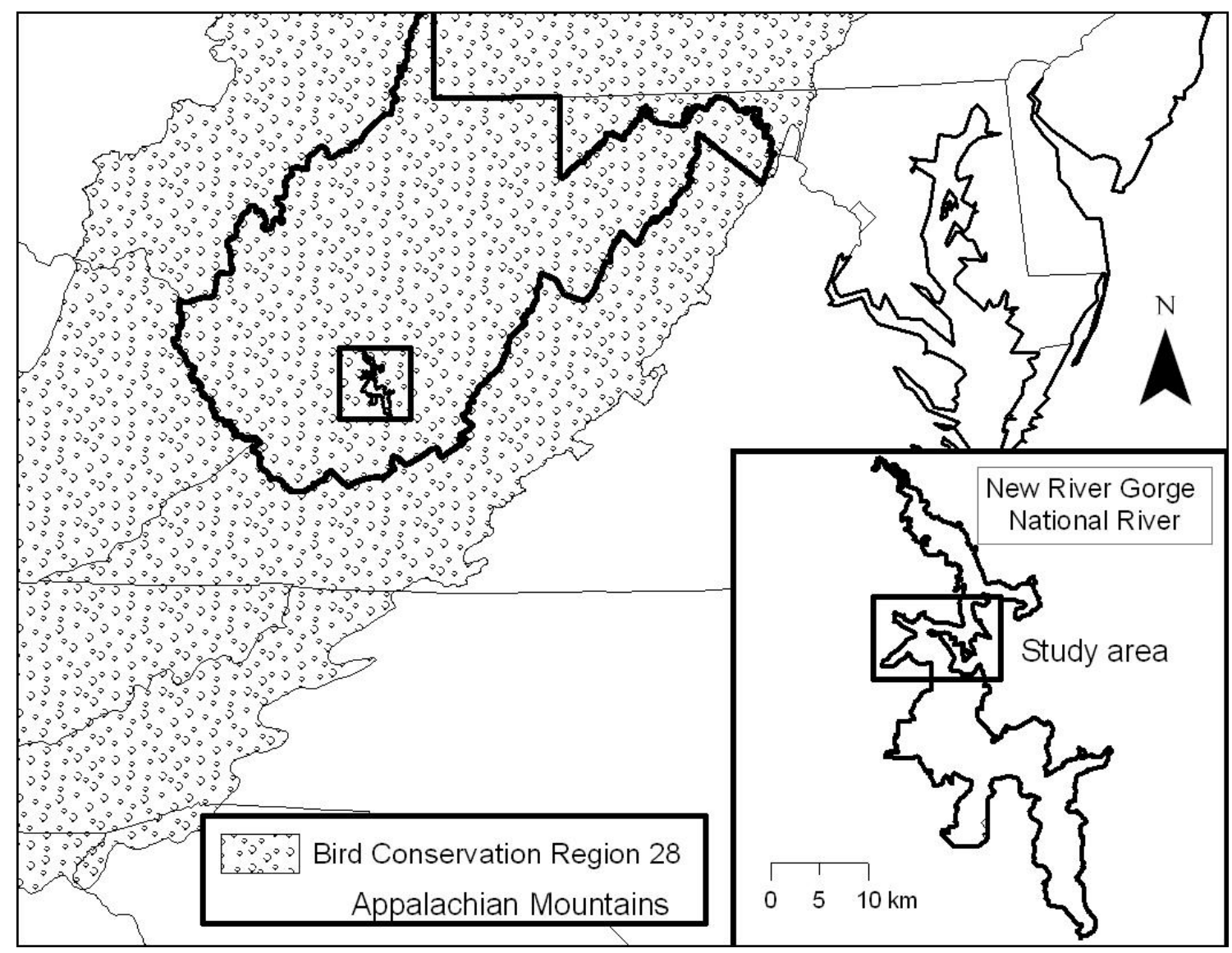


Appendix B. Aerial photograph (1945) showing early surface mining atop the New River Plateau. Initial mining at two study sites (2010-2011) is visible on the photograph.

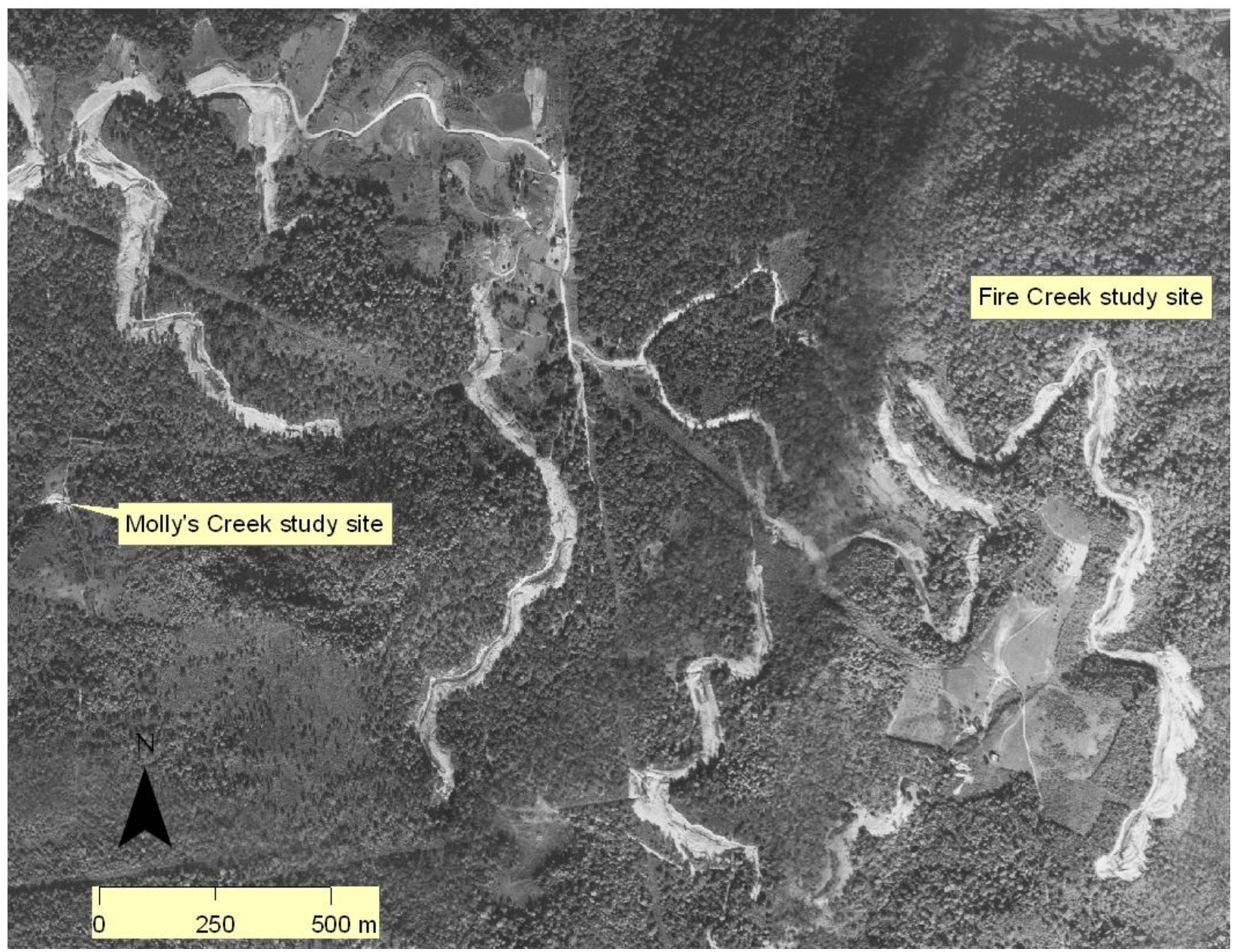


Appendix C. Breeding bird species detected during 2010-2011 surveys.

\begin{tabular}{|c|c|c|c|c|c|}
\hline Common Name & Code & Scientific Name & Foraging & Nesting & Habitat \\
\hline Acadian Flycatcher & $\overline{A C F L}$ & Empidonax virescens & $\mathrm{HK}$ & $\mathrm{SC}$ & $\mathrm{CC}$ \\
\hline American Redstart & AMRE & Setophaga ruticilla & $\mathrm{FG}$ & $\mathrm{SC}$ & $\mathrm{BC}$ \\
\hline American Robin & AMRO & Turdus migratorius & GG & $\mathrm{SC}$ & Gen \\
\hline Bk-throated Green Warbler & BTNW & Setophaga virens & $\mathrm{FG}$ & CA & $\mathrm{CC}$ \\
\hline Black-and-white Warbler & BAWW & Mniotilta varia & $\mathrm{BF}$ & GR & Gen \\
\hline Blackburnian Warbler & BLBW & Setophaga fusca & FG & CA & Gen \\
\hline Blue Jay & BLJA & Cyanocitta cristata & & & Gen \\
\hline Blue-gray Gnatcatcher & BGGN & Polioptila caerulea & FG & $\mathrm{CA}$ & Gen \\
\hline Blue-headed Vireo & BHVI & Vireo solitarius & FG & $\mathrm{CA}$ & $\mathrm{CC}$ \\
\hline Brown-headed Cowbird & $\mathrm{BHCO}$ & Molothrus ater & & & \\
\hline Carolina Chickadee & $\mathrm{CACH}$ & Poecile carolinensis & $\mathrm{FG}$ & $\mathrm{CV}$ & Gen \\
\hline Carolina Wren & CAWR & Thryothorus ludovicianus & GG & $\mathrm{CV}$ & $\mathrm{BC}$ \\
\hline Cerulean Warbler & CERW & Setophaga cerulea & FG & $\mathrm{CA}$ & $\mathrm{BC}$ \\
\hline Downy Woodpecker & DOWO & Picoides pubescens & $\mathrm{BF}$ & $\mathrm{CV}$ & Gen \\
\hline Eastern Phoebe & EAPH & Sayornis phoebe & $\mathrm{HK}$ & & Gen \\
\hline Eastern Towhee & EATO & Pipilo erythrophthalmus & GG & GR & $\mathrm{BC}$ \\
\hline Eastern Tufted Titmouse & ETTI & Baelophus bicolor & FG & $\mathrm{CV}$ & Gen \\
\hline Eastern Wood Pewee & EAWP & Contopus virens & HK & CA & $\mathrm{BC}$ \\
\hline Great Crested Flycatcher & GCFL & Myiarchus crinitus & $\mathrm{HK}$ & $\mathrm{CV}$ & Gen \\
\hline Hairy Woodpecker & HAWO & Picoides villosus & $\mathrm{BF}$ & $\mathrm{CV}$ & Gen \\
\hline Hooded Warbler & HOWA & Wilsonia citrina & FG & $\mathrm{SH}$ & $\mathrm{BC}$ \\
\hline Indigo Bunting & INBU & Passerina cyanea & FG & $\mathrm{SH}$ & $\mathrm{BC}$ \\
\hline Kentucky Warbler & KEWA & Oporornis formosus & GG & GR & $\mathrm{BC}$ \\
\hline Louisiana Waterthrush & LOWA & Seiurus motacilla & & GR & Gen \\
\hline Northern Cardinal & NOCA & Cardinalis cardinalis & $\mathrm{FG}$ & $\mathrm{SH}$ & $\mathrm{BC}$ \\
\hline Northern Parula & NOPA & Parula americana & FG & CA & Gen \\
\hline Ovenbird & OVEN & Seiurus aurocapillus & GG & GR & $\mathrm{CC}$ \\
\hline Pileated Woodpecker & PIWO & Dryocopus pileatus & $\mathrm{BF}$ & $\mathrm{CV}$ & $\mathrm{CC}$ \\
\hline Pine Warbler & PIWA & Setophaga pinus & $\mathrm{BF}$ & $\mathrm{CA}$ & Gen \\
\hline Red-bellied Woodpecker & RBWO & Melanerpes carolinus & $\mathrm{BF}$ & $\mathrm{CV}$ & Gen \\
\hline Red-eyed Vireo & REVI & Vireo olivaceus & FG & $\mathrm{CA}$ & Gen \\
\hline Rose-breasted Grosbeak & RBGR & Pheucticus ludovicianus & FG & $\mathrm{SC}$ & Gen \\
\hline Scarlet Tanager & SCTA & Piranga olivacea & FG & $\mathrm{CA}$ & Gen \\
\hline White-breasted Nuthatch & WBNU & Sitta carolinensis & $\mathrm{BF}$ & $\mathrm{CV}$ & Gen \\
\hline Winter Wren & WIWR & Troglodytes troglodytes & GG & $\mathrm{CV}$ & $\mathrm{CC}$ \\
\hline Wood Thrush & WOTH & Hylocichla mustelina & GG & $\mathrm{SC}$ & Gen \\
\hline Worm-eating Warbler & WEWA & Helmitheros vermivorus & FG & GR & Gen \\
\hline Yellow-billed Cuckoo & YBCU & Coccyzus americanus & FG & $\mathrm{SC}$ & Gen \\
\hline Yellow-throated Vireo & YTVI & Vireo flavifrons & FG & CA & Gen \\
\hline
\end{tabular}

Foraging guilds: HK (hawking), BF (bark forager), GG (ground gleaner), and FG (foliage gleaner). Nesting guilds: GR (ground), SH (shrub), SC (subcanopy), CA (canopy), CV (cavity). Habitat guilds: Gen (forest generalist), BC (broken canopy), CC (closed canopy). 
Appendix D. Relative importance values for tree species from reference $(n=56)$ and mineland $(n=56)$ forest plots sampled in New River Gorge NR, West Virginia in 2011.

\begin{tabular}{|c|c|c|c|}
\hline \multicolumn{2}{|c|}{ Mineland forest $(\mathrm{n}=56)$} & \multicolumn{2}{|c|}{$\underline{\text { Reference forest }(n=56)}$} \\
\hline Species & $\begin{array}{c}\text { Relative } \\
\text { importance }\end{array}$ & Species & $\begin{array}{l}\text { Relative } \\
\text { importance }\end{array}$ \\
\hline Yellow poplar & 0.973 & White oak & 0.529 \\
\hline Red maple & 0.795 & Red maple & 0.525 \\
\hline Black birch & 0.389 & Hickory spp. & 0.249 \\
\hline Black locust & 0.126 & Chestnut oak & 0.245 \\
\hline Sourwood & 0.105 & Black oak & 0.237 \\
\hline Black gum & 0.092 & Scarlet oak & 0.234 \\
\hline Princess tree & 0.062 & Yellow poplar & 0.175 \\
\hline Slippery elm & 0.060 & American beech & 0.152 \\
\hline Bigtooth aspen & 0.057 & Sourwood & 0.149 \\
\hline Black cherry & 0.045 & N. red oak & 0.105 \\
\hline White ash & 0.040 & Black gum & 0.078 \\
\hline River birch & 0.038 & Cucumber magnolia & 0.074 \\
\hline Sugar maple & 0.037 & Sugar maple & 0.070 \\
\hline Cucumber magnolia & 0.020 & Black birch & 0.046 \\
\hline Sycamore & 0.020 & Black cherry & 0.031 \\
\hline Sassafrass & 0.020 & Eastern hemlock & 0.025 \\
\hline Pitch pine & 0.019 & Hop hornbeam & 0.014 \\
\hline Virginia pine & 0.016 & Sassafrass & 0.014 \\
\hline N. red oak & 0.016 & White ash & 0.011 \\
\hline Box elder & 0.013 & Basswood & 0.008 \\
\hline American beech & 0.011 & Fraser magnolia & 0.008 \\
\hline Striped maple & 0.009 & Musclewood & 0.007 \\
\hline Black walnut & 0.007 & Flowering dogwood & 0.007 \\
\hline Black oak & 0.005 & Yellow buckeye & 0.006 \\
\hline Silver maple & 0.005 & & \\
\hline Flowering dogwood & 0.005 & & \\
\hline Prunus spp. & 0.005 & & \\
\hline Musclewood & 0.005 & & \\
\hline Wild crabapple & 0.005 & & \\
\hline
\end{tabular}


Appendix E. Detections $\mathrm{ha}^{-1}$ and percent occurrence for bird species detected along line transects in 2011 in mineland and reference forest in New River Gorge NR, West Virginia.

\begin{tabular}{|c|c|c|c|c|c|c|}
\hline & \multicolumn{3}{|c|}{ Mined $(n=14)$} & \multicolumn{3}{|c|}{ Reference $(n=14)$} \\
\hline & \multirow{2}{*}{$\begin{array}{c}\text { Percent } \\
\text { occurrence }\end{array}$} & \multicolumn{2}{|c|}{ Detections ha ${ }^{-1}$} & \multirow{2}{*}{$\begin{array}{c}\text { Percent } \\
\text { occurrence }\end{array}$} & \multicolumn{2}{|c|}{ Detections $\mathrm{ha}^{-1}$} \\
\hline & & mean & $\mathrm{SE}$ & & mean & $\mathrm{SE}$ \\
\hline Acadian Flycatcher & 7 & 0.04 & 0.04 & 36 & 0.17 & 0.07 \\
\hline American Redstart & 21 & 0.10 & 0.05 & 0 & & \\
\hline American Crow & 0 & & & 7 & 0.03 & 0.03 \\
\hline Black-and-white Warbler & 57 & 0.26 & 0.06 & 79 & 0.37 & 0.07 \\
\hline Blue-gray Gnatcatcher & 7 & 0.06 & 0.06 & 14 & 0.06 & 0.04 \\
\hline Brown-headed Cowbird & 0 & & & 7 & 0.03 & 0.03 \\
\hline Blue-headed Vireo & 7 & 0.03 & 0.03 & 64 & 0.37 & 0.11 \\
\hline Blue Jay & 21 & 0.09 & 0.05 & 7 & 0.03 & 0.03 \\
\hline Blackburnian Warbler & 14 & 0.10 & 0.07 & 36 & 0.17 & 0.07 \\
\hline Bk-thr. Green Warbler & 50 & 0.23 & 0.06 & 7 & 0.03 & 0.03 \\
\hline Carolina Chickadee & 43 & 0.23 & 0.08 & 14 & 0.06 & 0.04 \\
\hline Carolina Wren & 7 & 0.03 & 0.03 & 0 & & \\
\hline Cerulean Warbler & 14 & 0.06 & 0.04 & 0 & & \\
\hline Downy Woodpecker & 14 & 0.07 & 0.05 & 14 & 0.06 & 0.04 \\
\hline Eastern Phoebe & 7 & 0.03 & 0.03 & 0 & & \\
\hline Eastern Towhee & 21 & 0.10 & 0.05 & 0 & & \\
\hline Eastern Tufted Titmouse & 36 & 0.16 & 0.06 & 7 & 0.03 & 0.03 \\
\hline Eastern Wood-Pewee & 14 & 0.06 & 0.04 & 64 & 0.26 & 0.05 \\
\hline Great-crested Flycatcher & 7 & 0.03 & 0.03 & 29 & 0.11 & 0.05 \\
\hline Hairy Woodpecker & 29 & 0.13 & 0.06 & 50 & 0.23 & 0.07 \\
\hline Hooded Warbler & 21 & 0.13 & 0.07 & 14 & 0.06 & 0.04 \\
\hline Indigo Bunting & 14 & 0.06 & 0.04 & 0 & & \\
\hline Louisiana Waterthrush & 14 & 0.07 & 0.05 & 0 & & \\
\hline Northern Cardinal & 7 & 0.03 & 0.03 & 0 & & \\
\hline Ovenbird & 93 & 0.65 & 0.11 & 100 & 1.46 & 0.12 \\
\hline Pileated Woodpecker & 14 & 0.07 & 0.05 & 14 & 0.06 & 0.04 \\
\hline Red-bellied Woodpecker & 29 & 0.13 & 0.06 & 36 & 0.14 & 0.05 \\
\hline Red-eyed Vireo & 100 & 2.48 & 0.18 & 100 & 2.31 & 0.19 \\
\hline Scarlet Tanager & 93 & 0.81 & 0.12 & 100 & 0.68 & 0.08 \\
\hline White-breasted Nuthatch & 21 & 0.09 & 0.05 & 50 & 0.20 & 0.06 \\
\hline Worm-eating Warbler & 36 & 0.20 & 0.08 & 14 & 0.09 & 0.06 \\
\hline Wood Thrush & 14 & 0.06 & 0.04 & 36 & 0.14 & 0.05 \\
\hline Yellow-billed Cuckoo & 36 & 0.20 & 0.08 & 57 & 0.29 & 0.09 \\
\hline Yellow-throated Vireo & 21 & 0.10 & 0.05 & 29 & 0.11 & 0.05 \\
\hline
\end{tabular}


Appendix F. Location of study sites within Plum Orchard Wildlife Management Area (WMA) and New River Gorge National River in southern West Virginia (2010-2011).

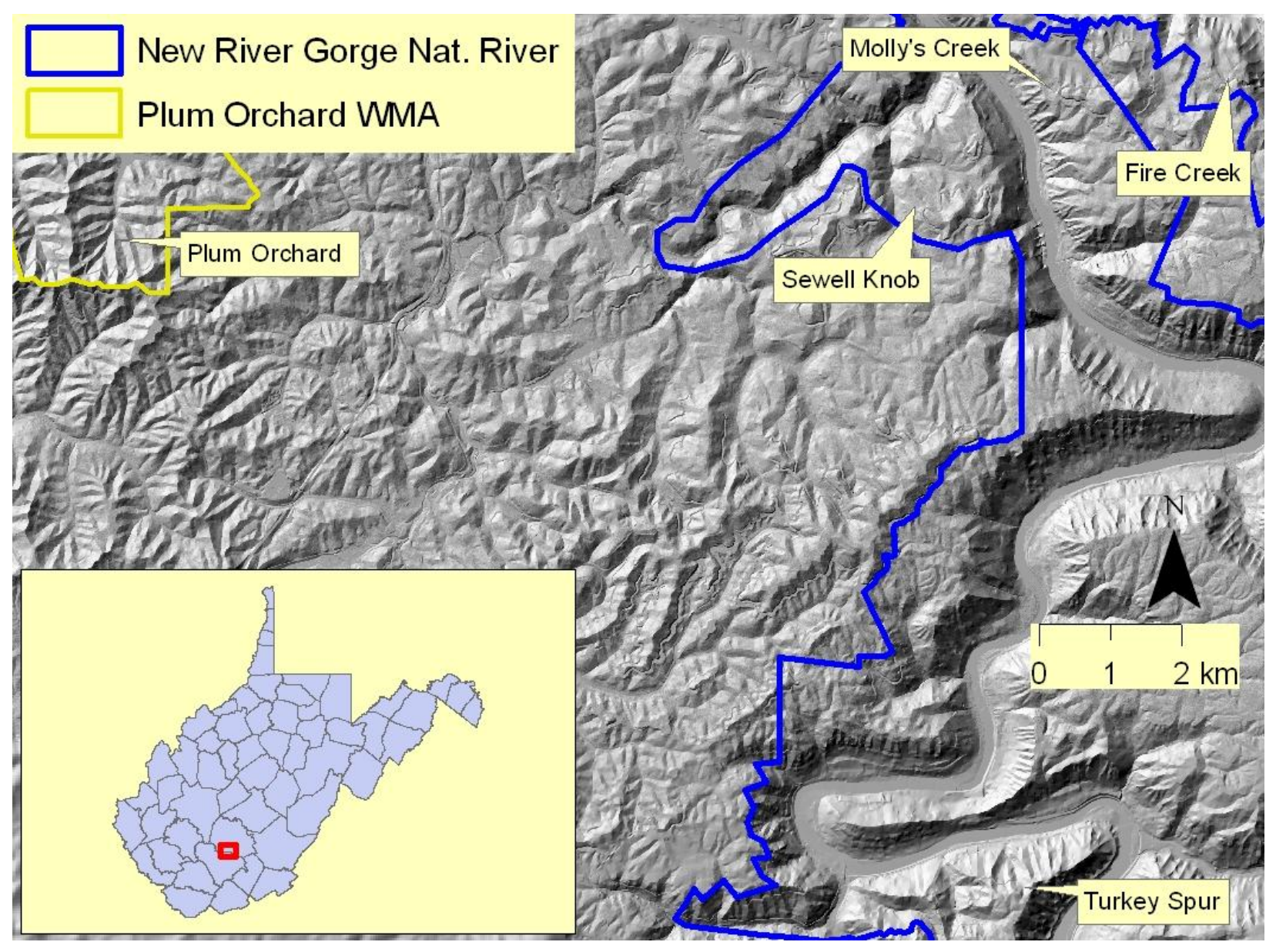


Appendix G. Relative importance values for tree species from plots categorized as loose-dumped benches ( $\mathrm{n}=33$ ), unmined plateau forest $(n=51)$, compacted benches $(n=20)$, and unmined, steep slope forest $(n=51)$. Only species with relative importance $\geq 0.05$ are shown. Plots were sampled in southern West Virginia in 2010.

\begin{tabular}{|c|c|c|c|c|c|c|c|}
\hline \multicolumn{2}{|c|}{ Loose-dumped benches (plateau) } & \multicolumn{2}{|c|}{$\underline{\text { Unmined (plateau) }}$} & \multicolumn{2}{|c|}{ Compacted benches (steep slope) } & \multicolumn{2}{|c|}{$\underline{\text { Unmined (steep slope) }}$} \\
\hline Species & Rel. importance & Species & Rel. importance & Species & Rel. importance & Species & Rel. importance \\
\hline Yellow poplar & 1.053 & Red maple & 0.568 & Yellow poplar & 0.792 & Red maple & 0.404 \\
\hline Red maple & 0.680 & Scarlet oak & 0.412 & Red maple & 0.553 & Sugar maple & 0.343 \\
\hline Black birch & 0.349 & White oak & 0.338 & Sugar maple & 0.427 & N. red oak & 0.331 \\
\hline Sourwood & 0.171 & Chestnut oak & 0.310 & Black birch & 0.227 & Chestnut oak & 0.288 \\
\hline Black gum & 0.124 & Yellow poplar & 0.230 & Black locust & 0.188 & Yellow poplar & 0.255 \\
\hline Princess tree & 0.092 & Sourwood & 0.210 & N. red oak & 0.128 & Hickory spp. & 0.224 \\
\hline Bigtooth aspen & 0.057 & Black oak & 0.176 & White ash & 0.101 & Basswood & 0.158 \\
\hline \multirow[t]{7}{*}{ Black cherry } & 0.050 & Hickory spp. & 0.141 & Princess tree & 0.058 & Black gum & 0.145 \\
\hline & & American beech & 0.128 & Chestnut oak & 0.057 & American beech & 0.106 \\
\hline & & Black gum & 0.125 & Hickory spp. & 0.056 & Sourwood & 0.105 \\
\hline & & Cucumber magnolia & 0.065 & & & Cucumber magnolia & 0.091 \\
\hline & & Black birch & 0.062 & & & Black oak & 0.089 \\
\hline & & Sugar maple & 0.056 & & & Black birch & 0.065 \\
\hline & & & & & & Scarlet oak & 0.064 \\
\hline
\end{tabular}


Appendix H. Percent occurrence and relative abundance $( \pm \mathrm{SE})$ for bird species detected during point count surveys conducted in New River Gorge NR and Plum Orchard WMA, southern West Virginia, in 2010. Plateau surveys were conducted atop the New River Plateau in unmined, oak-hickory forest $(\mathrm{n}=20)$ and adjacent forest bisected by loose-dumped minelands $(\mathrm{n}=17)$. Steep slope surveys were conducted in unmined, mixed-mesophytic forest $(n=14)$ and in adjacent forest bisected by compacted minelands $(n=14)$.

\begin{tabular}{|c|c|c|c|c|c|c|c|c|c|c|c|c|}
\hline & \multicolumn{3}{|c|}{$\begin{array}{l}\text { Loose-dumped minelands } \\
\text { (plateau) }\end{array}$} & \multicolumn{3}{|c|}{$\begin{array}{l}\text { Reference } \\
\text { (plateau) }\end{array}$} & \multicolumn{3}{|c|}{$\begin{array}{l}\text { Compacted minelands } \\
\text { (steep slope) }\end{array}$} & \multicolumn{3}{|c|}{$\begin{array}{c}\text { Reference } \\
\text { (steep slope) }\end{array}$} \\
\hline & $\%$ occurrence & mean & SE & $\%$ occurrence & mean & SE & $\%$ occurrence & mean & SE & $\%$ occurrence & mean & SE \\
\hline Acadian Flycatcher & 29 & 0.35 & 0.15 & 47 & 0.53 & 0.15 & 36 & 0.50 & 0.20 & 41 & 0.41 & 0.12 \\
\hline American Redstart & 0 & & & 0 & & & 57 & 1.57 & 0.50 & 59 & 0.88 & 0.21 \\
\hline American Robin & 0 & & & 0 & & & 29 & 0.36 & 0.17 & 0 & & \\
\hline Bk-thr. Green Warbler & 18 & 0.18 & 0.10 & 12 & 0.12 & 0.08 & 29 & 0.29 & 0.13 & 24 & 0.24 & 0.11 \\
\hline Black-and-white Warbler & 71 & 0.76 & 0.14 & 82 & 1.06 & 0.16 & 86 & 1.00 & 0.15 & 71 & 0.82 & 0.15 \\
\hline Blackburnian Warbler & 35 & 0.47 & 0.17 & 0 & & & 7 & 0.07 & 0.07 & 29 & 0.29 & 0.11 \\
\hline Blue Jay & 29 & 0.29 & 0.11 & 35 & 0.35 & 0.12 & 29 & 0.29 & 0.13 & 12 & 0.12 & 0.08 \\
\hline Blue-gray Gnatcatcher & 6 & 0.06 & 0.06 & 6 & 0.06 & 0.06 & 0 & & & 18 & 0.18 & 0.10 \\
\hline Blue-headed Vireo & 29 & 0.53 & 0.21 & 82 & 1.29 & 0.19 & 57 & 0.64 & 0.17 & 76 & 1.24 & 0.26 \\
\hline Brown-headed Cowbird & 12 & 0.12 & 0.08 & 6 & 0.06 & 0.06 & 43 & 0.43 & 0.14 & 18 & 0.18 & 0.10 \\
\hline Carolina Chickadee & 24 & 0.24 & 0.11 & 12 & 0.12 & 0.08 & 7 & 0.07 & 0.07 & 18 & 0.18 & 0.10 \\
\hline Carolina Wren & 6 & 0.06 & 0.06 & 12 & 0.12 & 0.08 & 0 & & & 0 & & \\
\hline Cerulean Warbler & 12 & 0.12 & 0.08 & 0 & & & 29 & 0.29 & 0.13 & 24 & 0.24 & 0.11 \\
\hline Downy Woodpecker & 0 & & & 6 & 0.06 & 0.06 & 7 & 0.07 & 0.07 & 12 & 0.12 & 0.08 \\
\hline Eastern Phoebe & 35 & 0.35 & 0.12 & 0 & & & 7 & 0.07 & 0.07 & 0 & & \\
\hline Eastern Towhee & 29 & 0.35 & 0.15 & 18 & 0.18 & 0.09 & 50 & 0.57 & 0.17 & 0 & & \\
\hline Eastern Tufted Titmouse & 12 & 0.12 & 0.08 & 29 & 0.29 & 0.11 & 29 & 0.29 & 0.13 & 29 & 0.29 & 0.11 \\
\hline Eastern Wood Pewee & 29 & 0.29 & 0.11 & 53 & 0.53 & 0.12 & 14 & 0.21 & 0.15 & 53 & 0.59 & 0.15 \\
\hline Great Crested Flycatcher & 6 & 0.06 & 0.06 & 18 & 0.18 & 0.09 & 7 & 0.07 & 0.07 & 0 & & \\
\hline Hairy Woodpecker & 12 & 0.12 & 0.08 & 47 & 0.53 & 0.15 & 29 & 0.36 & 0.17 & 35 & 0.35 & 0.12 \\
\hline Hooded Warbler & 53 & 0.65 & 0.17 & 24 & 0.35 & 0.17 & 79 & 1.36 & 0.27 & 47 & 0.76 & 0.24 \\
\hline Indigo Bunting & 6 & 0.06 & 0.06 & 6 & 0.06 & 0.06 & 0 & & & 0 & & \\
\hline
\end{tabular}


Appendix H. continued

\begin{tabular}{|c|c|c|c|c|c|c|c|c|c|c|c|c|}
\hline & \multicolumn{3}{|c|}{$\begin{array}{l}\text { Loose-dumped minelands } \\
\text { (plateau) }\end{array}$} & \multicolumn{3}{|c|}{$\begin{array}{r}\text { Unmined } \\
\text { (plateau) }\end{array}$} & \multicolumn{3}{|c|}{$\begin{array}{c}\text { Compacted minelands } \\
\text { (steep slope) }\end{array}$} & \multicolumn{3}{|c|}{$\begin{array}{c}\text { Unmined } \\
\text { (steep slope) }\end{array}$} \\
\hline & $\%$ occurrence & mean & SE & $\%$ occurrence & mean & SE & $\%$ occurrence & mean & SE & $\%$ occurrence & mean & SE \\
\hline Kentucky Warbler & 0 & & & 0 & & & 14 & 0.14 & 0.10 & 12 & 0.12 & 0.08 \\
\hline Louisiana Waterthrush & 0 & & & 6 & 0.06 & 0.06 & 0 & & & 0 & & \\
\hline Northern Cardinal & 0 & & & 0 & & & 29 & 0.29 & 0.13 & 0 & & \\
\hline Northern Parula & 6 & 0.06 & 0.06 & 0 & & & 0 & & & 0 & & \\
\hline Ovenbird & 100 & 2.18 & 0.21 & 100 & 3.18 & 0.41 & 86 & 1.50 & 0.25 & 100 & 2.24 & 0.20 \\
\hline Pileated Woodpecker & 24 & 0.24 & 0.11 & 24 & 0.24 & 0.11 & 7 & 0.07 & 0.07 & 6 & 0.06 & 0.06 \\
\hline Pine Warbler & 6 & 0.06 & 0.06 & 6 & 0.06 & 0.06 & 0 & & & 0 & & \\
\hline Red-bellied Woodpecker & 35 & 0.35 & 0.12 & 47 & 0.47 & 0.12 & 7 & 0.07 & 0.07 & 41 & 0.41 & 0.12 \\
\hline Red-eyed Vireo & 100 & 3.59 & 0.23 & 100 & 3.24 & 0.22 & 100 & 2.50 & 0.23 & 100 & 2.82 & 0.30 \\
\hline Rose-breasted Grosbeak & 0 & & & 0 & & & 71 & 0.86 & 0.18 & 29 & 0.29 & 0.11 \\
\hline Scarlet Tanager & 100 & 1.82 & 0.15 & 94 & 1.35 & 0.17 & 93 & 1.21 & 0.19 & 82 & 1.24 & 0.18 \\
\hline White-breasted Nuthatch & 29 & 0.29 & 0.11 & 29 & 0.29 & 0.11 & 7 & 0.07 & 0.07 & 35 & 0.35 & 0.12 \\
\hline Winter Wren & 0 & & & 0 & & & 7 & 0.07 & 0.07 & 0 & & \\
\hline Wood Thrush & 71 & 1.00 & 0.19 & 35 & 0.41 & 0.15 & 93 & 1.43 & 0.23 & 82 & 0.94 & 0.13 \\
\hline Worm-eating Warbler & 47 & 0.59 & 0.17 & 12 & 0.12 & 0.08 & 64 & 0.71 & 0.16 & 24 & 0.29 & 0.14 \\
\hline Yellow-billed Cuckoo & 29 & 0.29 & 0.11 & 29 & 0.29 & 0.11 & 29 & 0.29 & 0.13 & 29 & 0.29 & 0.11 \\
\hline Yellow-throated Vireo & 0 & & & 6 & 0.06 & 0.06 & 0 & & & 24 & 0.24 & 0.11 \\
\hline
\end{tabular}

John $\mathrm{H}$. 